\title{
Potencial de preparações do cogumelo comestível "shiitake" (Lentinula edodes) no controle de fitopatógenos fúngicos, bacterianos e virais em sorgo, maracujá e fumo
}

\section{Everaldo Piccinin}

Engenheiro Agrônomo

Orientador: Prof. Dr. Sérgio Florentino Pascholati

Tese apresentada à Escola Superior de Agricultura "Luiz de Queiroz", Universidade de São Paulo, para a obtenção do título de Doutor em Agronomia. Área de concentração: Fitopatologia

PIRACICABA

Estado de São Paulo - Brasil

Fevereiro -2.000 


\section{Errata}

\section{Agradecimentos especiais}

Onde consta Rosinha, lê-se Rosina

\section{Acrescentar à página 45, item 3.1.4. após último parágrafo}

Os cogumelos após a secagem ao sol apresentaram perda de peso (umidade) de aproximadamente $91,64 \%$ para basidiocarpo, $92,18 \%$ no píleo e $87,27 \%$ na estípe.

\section{Acrescentar à página 53, item 3.10. após primeiro parágrafo}

Os diferentes filtrados de $L$. edodes, foram submetidos diretamente ao teste enzimático, baseado no método de Lever (1972) onde utilizou-se como padrão o substrato laminarina. Foram utilizados $100 \mu \mathrm{l}$ de cada um dos filtrado para cada $100 \mu \mathrm{l}$ da enzima $\beta$-glicosidase (Sigma) com atividade de 5 unidades. Onde para cada unidade da enzima existe a liberação de $1 \mu \mathrm{mol}$ de glicose em 1 minuto à $37^{\circ} \mathrm{C}$. 


\section{Dados Internacionais de Catalogação na Publicação (CIP)}

\section{DIVISĀO DE BIBLIOTECA E DOCUMENTAÇĀO - Campus "Luiz de Queiroz"/USP}

Piccinin, Everaldo

Potencial de preparações do cogumelo comestivel "shiltake" (Lentinula edodes) no

controle de fitopatógenos fúngicos, bacterianos e virais em sorgo, maracujá e fumo /

Everaldo Piccinin. - - Piracicaba, 2000.

162 p. : if.

Tese (doutorado) - Escola Superior de Agricultura Luiz de Queiroz, 2000.

Bibliografia.

1. Bacteria fitopatogênica 2. Cogumelo comestivel 3. Controle biológico 4. Doença de planta 5. Fumo 6. Fungo fitopatogênico 7.Maracujả 8. Resistência induzida 9. Sorgo 10.

Virus fitopatogênico 1 . Título

CDD 635.8

Temitida a cópia total ou parcial deste documento desde que citala a fonte - O autor? 
Dedico,

à Thaís Rocha Pombo Pascholati, por todo auxílio prestado durante a execução dos ensaios e na elaboração dos originais desta tese, e principalmente pelo carinho, atenção e paciência durante todos estes anos. 
Agradecimentos especiais, aos meus pais Rosinha Gagliardi Piccinin e Celeste Piccinin, pelo carinho, dedicação, atenção e pelo apoio incondicional prestado durante todos estes anos, muito obrigado. 


\section{Agradecimentos}

Ao Prof. Dr. Sérgio Florentino Pascholati pela orientação, e pelo fornecimento da estrutura de laboratório e equipamentos, sem os quais não seria possivel o desenvolvimento deste trabalho.

Ao Dr. Alexandre Ferreira (CNPMS/EMBRAPA-SeteLagoas/MG) pelo fornecimento das sementes de sorgo.

Ao Dr. Breno Leite pelas dicas e sugestões durante a execução desta tese e pela leitura dos originais e sugestões oferecidas.

Aos colegas de laboratório: Célia Regina Tremacoldi, Fabiana Vieira Hoto, José Renato Stangarlin, Márcia Cristina Roncatto, Nelson Arno Wulf, e Thaís Rocha Pombo Pascholati, meu muito obrigado pela paciência, ajuda e amizade destes anos todos.

À Eng ${ }^{\mathrm{a}}$. Agro. Daniela Maria Toretta, pelo fornecimento de cogumelos durante a execução dos ensaios, e pela amizade nestes anos todos.

A Dr ${ }^{a}$. Erna Elizabeth Bach do Instituto Biológico de São Paulo pela dosagem de $\beta$-glucanas de todos os filtrados utilizados nos ensaios.

Aos técnicos de laboratório Fernanda Y. B. Groppo e José Rodolfo Groppo pela paciência e auxílio com materiais necessários durante os testes de laboratórios e pela amizade.

Ao Biólogo MS Hélio Mitoshi Kamida pelo auxílio na dosagem de açúcares e proteinas das amostras. 
Ao Prof. Dr. Jorge A. M. Rezende por permitir o uso de materiais, equipamentos e das dependências do Laboratório de Virologia Vegetal do Depto de Entomologia Fitopatologia e Zoologia Agrícola da Escola Superior de Agricultura "Luiz de Queiroz" - ESALQ/USP.

À $\operatorname{Dr}^{\mathrm{a}}$. Marina Capelari do Instituto de Botânica de São Paulo, pelo fornecimento de isolados de cogumelos comestíveis, depósito da cultura de $L$. edodes utilizada na tese, além das sugestões dadas no desenvolvimento da mesma.

Ao Dr. Masatomo Hirasawa da Universidade de Odontologia de Nihon no Japão pela gentileza no fornecimento de separatas referentes ao cogumelo shiitake.

Ao Eng.Químico e Diretor Indústrial da Ajinomoto Interamericana Indústria e Comércio, Nobuo Kimura pela cooperação no fornecimento das amostras de lentinan.

A Eng ${ }^{\text {a.. }}$ Agro. Patrícia Angélica Alves Marques pelo auxílio nas análises estatísticas, e pela amizade destes anos todos.

Ao Eng. Agro. MS Quelmo Silva de Novaes pelo auxílio nos ensaios com o vírus TMV.

Ao Eng. Agro. MS Robson M. Di Piero pela amizade e pela ajuda prestada durante a manutenção das plantas na casa de vegetação.

A Ajinomoto Interamericana Indústria e Comércio pela importação e fornecimento das amostras de Lentinan.

A Associação dos Produtores de Agricultura Natural (APAN), pelo auxilio em informações e materiais, e pelo apoio prestado durante a execução dos ensaios. 
A Cooperativa dos Produtores de Cogumelos de Rio Claro (COPCO), pelo incentivo e apoio durante estes anos todos

A Polícia Federal (posto Outlet Campinas), pela consideração, atenção e eficiência na liberação das amostras de lentinan provenientes do Japão, sem as quais alguns ensaios deixariam de ser realizados

Ao Depto de Entomologia, Fitopatologia e Zoologia Agrícola da Escola Superior de Agricultura "Luiz de Queiroz" - ESALQ/USP pelo uso dos laboratórios e área experimental do Setor de Fitopatologia.

Ao $\mathrm{CNPq}$ pela concessão da bolsa e suporte financeiro da pesquisa.

E a todos aqueles que de maneira direta ou indireta contribuíram auxiliando, criticando, sugerindo ou mesmo incentivando o desenvolvimento desta tese, meu muito obrigado. 


\section{Sumário}

\section{Página}

LISTA DE FIGURAS

LISTA DE TABELAS

iii

RESUMO

vii

SUMMARY

ix

1. INTRODUÇÃO

2. REVISÃO DE LITERATURA

2.1. Indução de resistência em plantas

2.1.1. Fisiologia da resistência de plantas - aspectos gerais

2.1.2. Indução de resistência - características

2.1.3. Indução de resistência local ou sistêmica

2.1.4. Indução de suscetibilidade

2. 2 . Controle biológico

2.3. Patossistemas

2.3.1. Sorgo - Exserohilum turcicum 24

2.3.2. Sorgo - Colletotrichum sublineolum 25

2.3.3. Maracujá - Xanthomonas campestris pv. passiflora 28

2.3.4. Vírus do mosaico do fumo (TMV) 30

2.4. Lentinula edodes (shiitake) 31

2.4.1. Uso potencial no controle de doenças de plantas 38

2.5. Perspectivas futuras 39 
3.1. Crescimento dos patógenos fúngicos, bacterianos e do shiitake

3.1.1. Exserohilum turcicum

3.1.2. Colletotrichum sublineolum

3.1.3. Xanthomonas campestris pv. passiflora 43

3.1.4. Lentimila edodes 44

3.2. Meio de cultura para os ensaios in vitro 45

3.3. Métodologias de repicagem e avaliação dos ensaios in vitro com os patógenos E. turcicum, C. sublineolum e X. campestris pv. passiflora

3.3.1. Repicagem e avaliação dos patógenos E. turcicum e C. 46 sublineolum

3.3.2. Repicagem e avaliação de $X$. campestris pv. passiflora 46

3.4. Obtenção das diferentes preparações de L. edodes 47

3.4.1. Preparo dos filtrados de basidiocarpo, píleo e estípe 47

3.4.2. Preparo do filtrado autoclavado de basidiocarpo, filtrado de 48 basidiocarpo autoclavado e filtrado congelado de preparações de basidicarpo

3.4.3. Filtrado de crescimento micelial e filtrado de micélio macerado 49

3.4.4. Lentinan 49

3.5. Métodos de incorporação das preparações de L. edodes in vitro 50

3.5.1 Em placas de Petri 50

3.5.2. Em tubos de ensaio $\quad 50$

3.6. Preparo de lâminas recobertas com poliestireno 51

3.7. A Avaliação da germinação e formação de apressórios in vitro na 51 presença de preparações de $L$. edodes

3.8. Determinação de carboidratos (açúcares solúveis) nas diferentes 52 preparações de $L$. edodes pelo método de Lever

3.9. Determinação de proteinas nas diferentes preparações de $L$. edodes 
3.10. Determinação de $\beta$-glucana nas diferentes preparações de $L$. edodes

3.11. Efeito das preparações de L. edodes no acúmulo de fitoalexinas em mesocótilos estiolados de sorgo

3.12. Efeito das preparações de $L$. edodes no acúmulo de gliceolina em cotilédones de soja

3.13. Efeito das preparações de L. edodes

3.13.1. Interações sorgo x E. turcicum e C. sublineolum 55

3.13.1.1. Aplicação das preparações de $L$. edodes e inoculação dos fungos 55

3.13.1.2. Avaliação dos ensaios com E. turcicum e C. sublineolum 56

3.13.2. Interação maracujá x X. campestris pv. passiflora 56

3.13.2.1. Aplicações das preparações de L. edodes e inoculações da bactéria $\quad 57$

3.13.2.2. Avaliação dos ensaios com X. campestris pv. passiflora 57

3.13.3. Interação fumo x vírus do mosaico do fumo (TMV) 58

3.13.3.1 Aplicação das preparações de L. edodes e inoculação do vírus 58

3.13.3.2. Avaliações dos ensaios com TMV $\quad 59$

$\begin{array}{lll}\text { 3.20. Análise estatística } & 60\end{array}$

4. RESULTADOS E DISCUSSÃO 61

4.1. Efeito das preparações das diferentes partes do cogumelo L. 61 edodes, secas ou congeladas, sobre o crescimento micelial e esporulação de E. turcicum

4.2. Efeito das preparações do basidiocarpo seco de L. edodes sobre o crescimento micelial e esporulação de E. turcicum e $C$. sublineolum sobre a multiplicação da bactéria $X$. campestris $\mathrm{pv}$. passiflora

4.3. Efeito da autoclavagem e congelamento das preparações de 72 basidiocarpo seco de L. edodes, na concentração de 20.000 ppm, sobre o crescimento micelial e esporulação de E. turcicum e $C$. sublineolum 
4.4. Efeito das preparações de L. edodes e do aquecimento dos mesmos à $45^{\circ} \mathrm{C}$, sobre a multiplicação de $X$. campestris pv. passiflora

4.5. Efeito do tempo de armazenamento das preparações de basidiocarpo de L. edodes em geladeira, e seu efeito no crescimento micelial e esporulação de E. turcicum

4.6. Efeito dos filtrados de crescimento micelial de L. edodes sobre o crescimento e esporulação de E. turcicum. e C. sublineolum e multiplicação de $X$. campestris pv. passiflora

4.7. Efeito do lentinan sobre a multiplicação de $X$. campestris $\mathrm{pv}$. passiflora

4.8. Efeito de diferentes preparações de $L$. edodes na germinação de 90 conídios e formação de apressórios por E. turcicum e $C$. sublineolum em lâminas recobertas com poliestireno

4.9. Dosagens de fitoalexinas em mesocótilos de sorgo e cotilédones de soja

4.10. Dosagens de: carboidratos, proteínas e $\beta$ 1,3-glucanas

4.11. Uso das diferentes preparações de $L$. edodes no controle de $E$. 102 turcium e $C$. sublineolum em sorgo, $X$. campestris pv. passiflora em maracujá e TMV em fumo

4.12. Comentário final

5 .

CONCLUSÕES

6. REFERÊNCIAS BIBLIOGRÁFICAS 


\section{Lista de Figuras}

\section{Página}

Figura 1. Basidiocarpos do cogumelo comestivel Lentinula edodes (shiitake) em toras de eucalipto

Figura 2. Curva padrão para a determinação do teor de açucares totais pelo método de Lever

Figura 3. Curva padrão para a dosagem de proteínas pelo método de Bradford

Figura 4. Escala diagramática para a avaliação da severidade de E. turcicum em folhas de sorgo

Figura 5. Efeito do filtrado de basidiocarpo seco, em diferentes concentrações, sobre o crescimento micelial de E. turcicum e $C$. sublineolum

Figura 6. Efeito dos filtrados de basidiocarpo, pileo e estípe secos, na concentração de 20.000 ppm, incorporados em água, com ou sem aquecimento à $45^{\circ} \mathrm{C}$, sobre o crescimento de $X$. campestris $\mathrm{pv}$. passiflora

Figura 7. Efeito do filtrado de crescimento micelial de L. edodes em diferentes concentrações, sobre o crescimento micelial de $E$. turcicum e C. sublineolum

Figura 8. Sintomas de E. turcicum (queima das folhas) e C. sublineolum (antracnose) em folhas de sorgo cvs. Brandes e Tx-398B, respectivamente

Figura 9. Sintomas de infecções locais e sistêmicas de $X$. campestris pv. passiflora (mancha oleosa do maracujazeiro), em folhas de maracujá azedo amarelo 
Figura 10. Sintomas de lesões locais e infecções sistêmicas do vírus do 123 mosaico do fumo em folhas de fumo cvs. TNN e Turkish 


\section{Lista de Tabelas}

\section{Página}

Tabela 1. Efeito do filtrado de diferentes partes do cogumelo $L$. edodes 62 (pileo e estípe), secas ou congeladas, sobre o crescimento micelial de E. turcicum

Tabela 2. Efeito do filtrado de diferentes partes cogumelo $L$. edodes (píleo e 63 estípe), secas ou congeladas, sobre a esporulação de E. turcicum

Tabela 3. Efeito do filtrado de diferentes preparações e concentrações do 66 cogumelo $L$. edodes seco sobre o crescimento micelial de $E$. turcicum

Tabela 4. Efeito do filtrado de diferentes preparações e concentrações do cogumelo $L$. edodes seco sobre sobre a esporulação do fungo $E$. turcicum

Tabela 5. Efeito do filtrado de diferentes preparações e concentrações do cogumelo $L$. edodes seco sobre o crescimento micelial de $C$. sublineolum

Tabela 6. Efeito do filtrado de diferentes preparações e concentrações do cogumelo $L$. edodes seco sobre sobre a esporulação de $C$. sublineolum

Tabela 7. Efeito do filtrado de diferentes preparações e concentrações do cogumelo $L$. edodes seco sobre a multiplicação de $X$. campestris pv. passiflora

Tabela 8. Efeito da autoclavagem sobre o filtrado de basidiocarpo seco de L. edodes, na concentração de 20.000 ppm, sobre o crescimento micelial e esporulação de E. turcicum 
Tabela 9. Efeito da autoclavagem sobre o filtrado de basidiocarpo seco de

L. edodes, na concentração de 20.000 ppm, sobre o crescimento micelial e esporulação de C. sublineolum

Tabela 10. Efeito da autoclavagem e congelamento nas preparações de 76 basidiocarpo de L. edodes, na concentração de 20.000 ppm, sobre o crescimento micelial e esporulação de $E$. turcicum

Tabela 11. Uso de diferentes combinações e modos de incorporação in vitro 78 dos preparados de $L$. edodes, na concentração de 20.000 ppm, sobre o crescimento micelial e esporulação de $E$. turcicum

Tabela 12. Efeito de diferentes filtrados de $L$. edodes, a concentração de 80 $20.000 \mathrm{ppm}$, e do aquecimento dos mesmos à $45^{\circ} \mathrm{C}$, sobre a multiplicação de $X$. campestris pv passiflora

Tabela 13. Efeito do armazenamento do filtrado de basidiocarpo de L. edodes em geladeira no crescimento micelial e esporulação de $E$. turcicum

Tabela 14. Efeito do filtrado do meio liquido utilizado para o crescimento micelial de L. edodes, em diferentes concentrações, sobre o crescimento micelial e esporulação de E. turcicum

Tabela 15. Efeito do filtrado do meio líquido utilizado para o crescimento micelial de L. edodes, em diferentes concentrações, sobre o crescimento micelial e esporulação de C. sublineolum

Tabela 16. Efeito do filtrado de meio liquido utilizado para o crescimento micelial de $L$. edodes, em diferentes concentrações, sobre a multiplicação de $X$. campestris pv. passiflora

Tabela 17. Efeito do meio líquido utilizado para o crescimento micelial de $L$. edodes, e aquecimento do mesmo à $45^{\circ} \mathrm{C}$, em diferentes concentrações, sobre a multiplicação de $X$. campestris pv. passiflora 
Tabela 18. Efeito do lentinan, na concentração de $20.000 \mathrm{ppm}$, sobre a multiplicação de $X$. campestris pv. passiflora

Tabela 19. Efeito de diferentes preparações de L. edodes nas concentração de 20.000 e 50.000 ppm sobre a germinação de conídios e formação de apressórios por E. turcicum em lâminas recobertas de poliestireno

Tabela 20. Efeito de diferentes preparações de L. edodes à concentração de 20.000 ppm, sobre a germinação de conídios e formação de apressórios por C. sublineolum sobre lâminas recobertas de poliestireno

Tabela 21. Dosagem de fitoalexinas em mesocótilos de sorgo Brandes após o tratamento com de diferentes preparações de $L$. edodes medidos à 480 nm de absorbância

Tabela 22. Efeito de diferentes preparações de $L$. edodes no acúmulo de gliceolina em cotilédones de soja var. IAC-8

Tabela 23. Conteúdo de carboidratos (açúcares solúveis) em diferentes preparações de L. edodes

Tabela 24. Conteúdo de proteinas em diferentes preparações de L. edodes

Tabela 25. Conteúdo de de $\beta$-glucana em diferentes preparações de $L$. edodes

Tabela 26. Sumário dos resultados referentes à avaliação do crescimento micelial e esporulação in vitro, germinação de conídios e formação de apressórios em lâminas recobertas com poliestireno para E. turcicum e C sublineolum, multiplicação in vitro de $X$. campestris pv. passiflora e acúmulo de fitoalexinas em sorgo e soja em resposta ao tratamento com as diferentes preparações de L. edodes

Tabela 27. Efeito de diferentes preparações de L. edodes sobre a severidade de E. turcicum em folhas de sorgo (cv. Brandes) 
Tabela 28. Efeito de diferentes preparações de $L$. edodes sobre a severidade 105 de C. sublineolum em folhas de sorgo (cv. Tx 398-B)

Tabela 29. Efeito de diferentes preparações de $L$. edodes sobre a incidência 107 média de infecções locais e sistêmicas de $X$. campestris pv. passiflorae em folhas de maracujá amarelo azedo

Tabela 30. Efeito de diferentes preparações de $L$. edodes sobre a incidênica 108 média de lesões locais em fumo $\mathrm{TNN}$ e sistêmicas em fumo Turkish, avaliadas aos 15 e 30 dias após a inoculação com TMV 


\title{
Potencial de preparações do cogumelo comestível "shiitake"
}

\section{(Lentinula edodes) no controle de fitopatógenos fúngicos,} bacterianos e virais em sorgo, maracujá e fumo

\author{
Autor: Everaldo Piccinin \\ Orientador: Prof. Dr. Sérgio Florentino Pascholati
}

Resumo

Este trabalho foi realizado com o objetivo de determinar o efeito de diferentes preparações do cogumelo L. edodes, sobre fitopatógenos fúngicos, bacterianos e virais, em condições de laboratório e casa de vegetação. Foram preparados extratos aquosos do cogumelo, a partir de basidiocarpos secos e autoclavados, pileo e estipe. Foram também obtidos filtrados a partir de crescimento micelial em meio líquido e micélio seco proveniente do mesmo meio de cultura.

Os extratos foram incorporados aos meios de cultura, a fim de se verificar o efeito sobre o crescimento micelial, esporulação, germinação de conídios e formação de apressórios pelos fungos Exserohilum turcicum e Colletotrichum sublineolum e sobre a multiplicação da bactéria Xanthomonas campestris pv. passiflora. Os resultados evidenciaram que os filtrados de basidiocarpo, pileo, estípe, filtrado de basidiocarpo autoclavado e filtrado de crescimento micelial reduziram o crescimento micelial e inibiram completamente a germinação dos conídios e a formação de apressórios. apenas para os filtrados de basidiocarpo, píleo e estípe, os quais mostraram-se termo lábeis.

As diferentes preparações do shiitake, quando misturadas a suspensão de $X$. campestris pv. passiflora, apresentaram efeito bactericida para os filtrados de estípe e crescimento micelial, sendo que para os filtrados de basidiocarpo e pileo, observou-se apenas redução no crescimento bacteriano. Todos os filtrados mostraram-se termolábeis à partir de $45^{\circ} \mathrm{C}$. 
A elicitação de fitoalexinas do complexo das deoxiantocianonidinas em sorgo e gliceolina em soja foi observada para todas as preparações testadas, exceto para o lentinan, o qual também não apresentou inibição dos patógenos testados in vitro. Nos ensaios com plantas, os filtrados de basidiocarpo, além do lentinan, reduziram a severidade de E. turcicum e C. sublineolum em folhas de sorgo cv. Brandes e cv. Tx398B, respectivamente, além do controle de lesões locais em fumo cv. TNN. Porém, nenhuma das preparações foi efíciente no controle de infecções sistêmicas em fumo cv. Turkish. Os filtrados de basidiocarpo, estípe e crescimento micelial do L. edodes, assim como o lentinan, reduziram a incidência de infecções locais e sistêmicas de $X$. campestris pv. passiflora em maracujazeiro.

Pelos resultados obtidos conclui-se que os filtrados de basidiocarpo, pileo estipe e crescimento micelial, apresentam substâncias com atividade antibiótica in vitro para os fitopatógenos E. turcicum, C sublineolum e $X$. campestris pv. passiflora. Além dos experimentos em casa de vegetação terem evidenciado o uso potencial das preparações do cogumelo shiitake e do lentinan na proteção de plantas à patógenos fúngicos, bacterianos e virais. 


\title{
Potential of preparations of the edible mushroom "shiitake" (Lentinula edodes) to control fungical, bacterial and viral pathogens, in sorghum, passionflower and tobacco
}

\author{
Author: Everaldo Piccinin \\ Advisor: Prof. Dr. Sérgio Florentino Pascholati
}

\section{Summary}

This work was accomplished with the objective of determining the effect of different preparations of the mushroom Lentinula edodes on fungal, bacterial and viral plant pathogens, under laboratory and greenhouse conditions. Aqueous extracts of the mushroom, from dry basidiocarp autoclaved or not, cap and stem. Filtrates were obtained from the fungus growing in liquid media and dry mycelia from the same medium.

The filtrates and extracts were incorporated in to the culture media to verify the effect on mycelial growth, sporulation, conidium germination and appressoria formation by the fungi Exserohilum turcicum and Colletotrichum sublineolum, and on the multiplication of the bacteria Xanthomonas campestris pv. passiflora. The results indicated that filtrates from basidiocarp, cap and stem, filtrate from autoclaved basidiocarp and from mycelial growth caused a reduction on growth of the fungal plant pathogen. A complete inhibition of conidium germination and apressoria formation were only observed for the basidiocarp, cap and stem filtrates, wich were thermolabile.

The stem and mycelia growth filtrates from shiitake when added to a suspension of $X$. campestris pv. passiflora exhibited a bactericidal effect, while the filtrates from basidiocarp and cap caused a reduction in bacterial growth. All these filtrates were demonstrated to be thermolabile above the temperature of $45^{\circ} \mathrm{C}$. 
The elicitation of phytoalexins of the deoxyanthocyanidin complex in sorghum and glyceolin in soybean was observed in response to all preparations tested, except to lentinan, that did not presented any inhibition of the pathogens tested in vitro. In experiments with plants, the basidiocarp filtrates and lentinan reduced the severity of $E$. turcicum and C. sublineolum in sorghum leaves besides the number of local lesions in tobacco plants $\mathrm{cv}$. TNN. However, none of the preparations were efficient in the control of systemic infections in tobacco plants cv. Turkish. On the other hand, the filtrates of the basidiocarp, stem and mycelial growth besides lentinan reduced the incidence of local and systemic infections of $X$. campestris pv. passiflora in passionflower.

Based upon the results, it was shown that the filtrates of basidiocarp, cap, stem and mycelial growth of $L$. edodes, contain substances with antibiotic activity in vitro against the plant pathogens $E$. turcicum, $C$ sublineolum and $X$. campestris pv. passiflora. Besides that, the experiments under greenhouse conditions showed the potential of the shiitake preparations and lentinan in the protection of plants against fungal, bacterial and viral pathogens. 


\section{INTRODUÇÃO}

As doenças de plantas sempre causaram preocupação ao homem devido aos seus efeitos muitas vezes devastadores na destruição das culturas. Seus efeitos são refletidos principalmente na fome e algumas vezes inclusive em mortes, gerando assim problemas sociais mais sérios que apenas os danos econômicos.

Deste modo, muitos estudos que visassem desvendar e compreender a origem das doenças de plantas foram sendo desenvolvidos. Porém, mais importante que compreender este mecanismo era a necessidade de se interferir neste processo a fim de controlar as doenças.

Com o desenvolvimento da microbiologia, foi criado também um conhecimento mais sólido e refinado a respeito dos microrganismos e suas interações com o meio, e como conseqüência deste avanço, foram sendo desenvolvidos os primeiros princípios sobre o manejo e controle de doenças.

Um dos marcos no controle de doenças foi a descoberta da calda bordalesa, o primeiro fungicida desenvolvido pelo homem. Após este produto, muitos outros foram descobertos e desenvolvidos, principalmente com ação protetora. Com o avanço das pesquisas, foram surgindo também os primeiros fungicidas de ação sistêmica, os quais atualmente vem suplantando o desenvolvimento de produtos meramente protetores. 
Contudo, os fungicidas também apresentam limitações no controle das doenças de plantas, principalmente com respeito à ineficiência dos produtos existentes a alguns grupos de fitopatógenos, e também a problemas com resistência de microrganismos aos fungicidas empregados. Deste modo, métodos alternativos ou complementares de controle e manejo de doenças de plantas sempre co-existiram ao uso dos fungicidas, sendo muitas vezes uma necessidade o uso de mais de uma técnica de controle para a convivência com determinados fitopatógenos.

Atualmente, uma das principais preocupações do homem é quanto à preservação dos recursos naturais que ainda restam, o ambiente em que vivemos, bem como os alimentos que consumimos. Deste modo, o uso de produtos com menor grau de toxidez e que afetem o mínimo possivel os demais seres vivos é uma necessidade que vem crescendo a cada ano. O mercado consumidor também apresenta uma maior preocupação com a presença de resíduos de defensivos agricolas nos produtos que são consumidos, exigindo assim produtos com melhor aparência, qualidade e principalmente produzidos com reduzido uso de defensivos. Esta exigência é ainda maior com relação ao mercado externo, onde os produtos que são exportados devem estar rigorosamente dentro de determinados padrões quanto à presença de resíduos de defensivos, e que muitas vezes não podem ser obtidos via controle químico tradicional.

Deste modo, o uso de técnicas alternativas para o controle de doenças de plantas é uma necessidade cada vez maior. Entre estas técnicas, temos o controle biológico de doenças de plantas e também o uso da indução de proteção, a qual já foi demonstrada ser possivel de ser obtida em campo e não apenas em condições controladas. Neste sentido, o presente trabalho visa a utilização do cogumelo comestível "shiitake" para o controle de fitopatógenos, visto que o mesmo é utilizado milenarmente na China e no Japão visando o controle de doenças humanas, como tumores.

Além disso, esse cogumelo apresenta efeitos antivirais, antifúngicos, antibacterianos, antitrombótico, potencializador de interferon (substància utilizada no tratamento de câncer), bem como efeitos na regeneração de pele e óssea, ação antiúlcera, anti-asmático e anti-colesterol. 
Porém, são estudos restritos à área médica, sendo que na área agrícola, são raros os trabalhos demonstrando a possibilidade do uso do shiitake no controle de fitopatógenos. E com base nos bons resultados obtidos com o uso do cogumelo shiiitake no controle de microrganismos em humanos, desperta-nos o interesse, de qual seria a ação de extratos do cogumelo em plantas. Será que os mesmos efeitos seriam observados?

Assim sendo o presente trabalho tem como finalidade avaliar a possibilidade do uso de preparações deste cogumelo na proteção de plantas de sorgo a: C. sublineorum e o E. turcicum, e maracujá amarelo azedo a $X$. campestris pv. passiflora e fumo ao vírus do mosaico do fumo (TMV). 


\section{REVISÃO DE LITERATURA}

\subsection{Indução de resistência em plantas}

Como regra geral na natureza, as espécies vegetais possuem mecanismos eficientes que impedem o estabelecimento e o desenvolvimento da maioria dos organismos patogênicos, porém alguns conseguem vencer as defesas dos vegetais e ocasionar a doença. Deste modo, resulta o conceito de que a resistência é a regra e a susceptibilidade uma exceção (Moraes, 1991; Lopez, 1993; Pascholati \& Leite, 1994).

Quando o sistema de defesa da planta mostra-se ineficiente ou inoperante, o patógeno tem condições de iniciar o processo infeccioso e instalar-se nos tecidos do hospedeiro, ocasionando no mesmo distúrbios ao nível bioquímico e fisiológico, que se traduzem no surgimento dos sintomas da doença (Leite \& Pascholati, 1995; Moraes, 1991).

Mas, por que a expressão de resistência de uma planta é funcional em apenas alguns casos? Este questionamento levou à hipótese de que os mecanismos de resistência estivessem inativos ou reprimidos nas interações compatíveis entre espécies ou cultivares susceptíveis e patógenos virulentos. Portanto, se os genes responsáveis pela defesa da planta estão inativos nestes casos, como ativá-los ? 
Ray (1901) foi um dos pioneiros em demonstrar o que classificou de "vacinação de plantas" com formas atenuadas de fungos causadores de ferrugem. $\mathrm{Na}$ mesma linha, Bernard (1909) inoculou bulbos de orquídea com um isolado fraco de Rhizoctonia repens, e demonstrou que quando estas mesmas plantas eram inoculadas com um isolado virulento do patógeno, as plantas não exibiam doença. Anos mais tarde, foi demonstrado que um dos fatores da proteção induzida nos bulbos de orquidea envolvia, em parte, o acúmulo de compostos fenólicos.

Ward (1905) e Stackman (1915) observaram também que plantas de trigo expostas a isolados avirulentos de fungos causadores de ferrugem, mostravam-se resistentes quando da inoculação com isolados virulentos do mesmo patógeno. Smith et al. (1911) e Brown (1923) demonstraram que a aplicação de preparações de Agrobacterium tumefaciens, inativados termicamente ou não, conferiam proteção às plantas a infecções posteriores pela própria bactéria.

Müller \& Borger (1940) e Müller (1956; 1961) demonstraram que tubérculos de batata, quando inoculados com isolados avirulentos de Phytophthora infestans, tornavam-se resistentes a inoculações subsequentes com formas virulentas do fungo. Assim, a partir da demonstração da existência do fenômeno da indução de resistência em plantas, muitos trabalhos começaram a ser conduzidos visando o entendimento dos mecanismos bioquímicos e fisiológicos decorrentes da ativação dos genes de defesa.

\subsubsection{Fisiologia da resistência de plantas - aspectos gerais}

A resistência de um hospedeiro, dentro do contexto da fisiologia do parasistismo, pode ser definida como a capacidade da planta em atrasar ou evitar a entrada e/ou a subsequente atividade de um patógeno em seus tecidos (Pascholati \& Leite, 1995). 
Neste sentido, as plantas apresentam diversos mecanismos de resistência que são divididos didaticamente em duas categorias: a) mecanismos pré-formados (passivos, constitutivos), que são subdivididos ainda em estruturais (cuticula, tricomas, estòmatos, vasos condutores, etc) e bioquímicos (fenóis, alcalóides, lactonas insaturadas, glicosídeos cianogènicos, glicosídeos fenólicos, fototoxinas, inibidores proteicos, $\beta-1,3$ glucanase, quitinase, etc) e mecanismos pós-formados (ativos; induziveis), que também são subdivididos em estruturais (papilas, halos, lignificação, camadas de cortiça, tiloses, etc) e bioquímicos (fitoalexinas e proteínas relacionadas à patogênese) (Moraes, 1991; Bell, 1981; Isaac, 1992; Mansfield, 1983; Aist, 1983; Pascholati \& Leite, 1994).

De modo geral, a indução de resistência em plantas está relacionada a mecanismos estruturais e bioquímicos pós-formados. Os mecanismos bioquímicos préformados podem ser considerados também como passiveis de serem induzidos, pois como resultado da infecção as substâncias já existentes podem ser convertidas em outras substâncias altamente tóxicas aos fitopatógenos, ou ainda podem ter seu acúmulo aumentado rapidamente em resposta a uma possível agressão externa (Pascholati \& Leite, 1994).

Aumentos na atividade de hidrolases, como $\beta$ 1-3 glucanases e quitinases, estão frequentemente associados com os mecanismos de defesa das plantas. Embora possam estar ou não presentes em baixas quantidades nas plantas, essas enzimas podem ser acumuladas rapidamente pela ação de algum tipo de indutor biótico ou abiótico (Boller, 1987; Roulin \& Bucchala, 1995). Guzzo \& Martins (1996) utilizando de Bacillus thuringiensis como indutor de proteção, observaram que o controle da ferrrugem do cafeeiro, causada por Hemileia vastatrix, estava relacionada ao aumento da atividade de $\beta$ 1-3 glucanase e quitinases nas plantas elicitadas. Na mesma linha, Xue et al. (1998) obtiveram controle de C. lindemuthianum em plantas de feijão pela aplicação de isolados não patogênicos e binucleados de Rhizoctonia solani, onde os autores observaram os aumentos na atividade de $\beta$ 1-3 glucanases e quitinases, além de aumento na concentração de peroxidases. 
Embora a função biológica das peroxidases não seja muito bem conhecida, sabe-se que as mesmas participam da biossintese da parede celular, dos processos de lignificação, e formações de caloses, tiloses, suberificação e produção de compostos fenólicos (Lamport, 1986).

Dentre os mecanismos bioquímicos de resistência pós formados, as fitoalexinas ocupam lugar de destaque. Neste sentido, devido à importância das mesmas na proteção de diversas plantas, inclusive sorgo, abordaremos a seguir alguns aspectos desse mecanismo de resistência a fitopatógenos.

As fitoalexinas são compostos anti-microbianos, de baixo peso molecular, que são sintetizados pelas plantas e se acumulam nas células vegetais em resposta a uma infecção microbiana (Paxton, 1981; Stoessl, 1986). Atualmente, sabe-se que não apenas os fitopatógenos são capazes de induzir ou elicitar a produção de fitoalexinas, mas também outros microrganismos não patogênicos, como por exemplo, Saccharomyces cereviseae e Bacillus thuringiensis e agentes abióticos, como $\mathrm{HgCl}_{2} \mathrm{e}$ luz U.V. (Freitas et al., 1993). As fitoalexinas podem também ser elicitadas endogenamente, devido à ação de oligossacarídeos dos fitopatógenos, liberados em função da ação das $\beta-1,3$ glucanases e quitinases sobre a parede celular (Pascholati \& Leite, 1994).

Roncatto \& Pascholati (1993) evidenciaram a produção de fitoalexinas em mesocótilos estiolados de sorgo, a partir do tratamento com filtrado de suspensões da levedura Saccharomyces cerevisiae e "Fermento Biológico Fresco Fleischmann". Foi observado também um aumento na concentração de fitoalexinas, linear ao aumento da concentração de levedura aplicada, assim como a produção de fitoalexinas foi mais intensa quando aplicado o fermento biológico, indicando que a presença das células de levedura está ligada diretamente ao efeito de proteção. Lopez (1993) e Tenkouano et al. (1993) consideram a utilidade da seleção de plantas de sorgo que expressam mais rapidamente e eficientemente o acúmulo das fitoalexinas, pois como já demonstrado, as mesmas estão intimamente relacionadas com a defesa do sorgo contra fitopatógenos. 
Snyder \& Nicholson (1990) demonstraram a formação de fitoalexinas em sorgo 24h após a aplicação de suspensões conidiais de C. graminicola. Foi observado o aparecimento de pequenas vesiculas, contendo as fitoalexinas conhecidas como apigeninidina e luteolinidina. Estas vesículas acumulavam-se ao redor do ponto de infecção, impedindo o estabelecimento do patógeno. Outro aspecto importante diz respeito à coloração das fitoalexinas de sorgo, visto serem as únicas fitoalexinas coloridas que se conhece, o que facilita a visualização direta do acúmulo das mesmas nas células de plantas dessa gramínea.

O controle da antracnose do sorgo causada por C. graminicola, entre outros fatores deve-se, ao efeito protetor das fitoalexinas, bem como à velocidade de resposta da planta no acúmulo destes compostos (Snyder \& Nicholson, 1990; Tenkouano et al., 1993; Lopez, 1993). Stangarlin et al. (1994) relataram que a resposta de plantas de sorgo a "queima das folhas" ou mancha foliar causada por E. turcicum, também envolve o acúmulo de fitoalexinas do tipo apigeninidina, luteolinidina e ester de apigeninidina. Essas fitoalexinas são semelhantes às produzidas contra C. graminicola, demonstrando também a inespecificidade dessas substâncias quanto aos fitopatógenos controlados.

Hoos \& Blaich (1990) e Jeandet et al. (1995) demonstraram que videiras acumulam a fitoalexina resveratrol em resposta à infecção com $B$. cinerea, $P$. viticola $\mathrm{e}$ outros fitopatógenos. Hoos \& Blaich (1990) observaram através de estudos in vitro que B. cinerea e $P$. viticola têm o crescimento micelial reduzido na concentração de $50 \mathrm{ppm}$ de resveratrol, enquanto que $500 \mathrm{ppm}$ induz a um crescimento lento até paralisá-lo totalmente. Porém, B. cinerea possui mecanismos enzimáticos capazes de degradar o resveratrol, através da produção de lactases, as quais promovem a detoxificação da fitoalexina através de reações oxidativas. Em trabalho correlato Pezet \& Pont (1990) descrevem a fitoalexina pterostilbeno, produzida pela videira, como capaz de atuar sobre ribossomos, retículo endoplasmático, mitocôndrias e membrana nuclear do $B$. cinerea. Agindo sobre a membrana plasmática, desorganizando-a completamente em 3 horas e inibindo a respiração em $10 \mathrm{~min}$, pterostilbeno difere do resveratrol, principalmente pela velocidade de acúmulo e modo de ação sobre o patógeno. 


\subsubsection{Indução de resistência - características}

O tratamento previo de plantas, a fim de conferir proteção pela ativação dos mecanismos de defesa estruturais e bioquímicos das mesmas, protegendo-as contra fungos, vírus e bactérias é conhecido como indução de resistência (Madamanchi \& Kuc, 1991; Martinelli, 1992; Martins, 1991; Moraes, 1991; Pascholati, et al. 1986; Pascholati \& Leite, 1994; 1995). Para que o processo de indução de resistència seja desencadeado é necessário que ocorra algum estímulo na planta hospedeira, para que os mecanismos latentes de resistência da planta sejam ativados (Pascholati \& Leite, 1995). Os agentes capazes de provocar este estímulo nas plantas são chamados de indutores ou elicitores, os quais podem ser divididos em bióticos e abióticos. Os elicitores bióticos são representados por microrganismos saprófitas, próprio patógeno ou patógenos de outras culturas, onde os mesmos podem estar na forma virulenta, avirulenta ou inativada.

Também podem englobar metabólitos microbianos e extratos de plantas sadias ou imunizadas (Sequeira, 1979; Kuc \& Rush, 1985; Duke et al., 1987; Moraes, $1989 ; 1990)$. No Brasil, alguns dos microrganismos comumente utilizados em pesquisas com indução de proteção têm sido Bacillus thuringiensis e Saccharomyces cereviseae, devido às facilidades encontradas na aquisição de formulações comerciais, além dos resultados já obtidos com os mesmos serem promissores (Freitas et al., 1993; Lopez, 1991; Moraes, 1991; Roncatto \& Pascholati, 1993; Roveratti, 1989; Silva, 1989; Stangarlin \& Pascholati, 1994).

Piccinin (1995) demonstrou também a possibilidade do uso de $S$. cereviseae no controle de E. turcicum e C. graminicola em plantas de sorgo em condições de campo, onde os tratamentos com a levedura proporcionaram um controle equivalente ao do controle químico.

Os mais variados tipos de elicitores abióticos são utilizados no estudo do fenômeno de indução de proteção. Dentre eles, temos luz UV, injúria mecànica com carborundum, tratamento com $\mathrm{HgCl}_{2}, \mathrm{NaCl}$ e nitrogênio líquido (Freitas et al., 1993; Pascholati \& Leite, 1995), além de nutrientes como $\mathrm{Na}_{2} \mathrm{H}_{2} \mathrm{PO}_{4}$ (Fernanández et al., 1996) $\mathrm{K}_{2} \mathrm{HPO}_{4}$ e $\mathrm{MnCl}_{2}$ (Reuveni, et al., 1997). 
Bhattacharyya \& Roy (1998) obtiveram indução de proteção em plantas de arroz contra $R$. solani, pelo uso de selenito de sódio, sulfato de zinco, sulfato de lítio, fluoreto de sódio, cloreto de ferro e nitrato de cálcio.

O ácido salićlico tem sido outro elicitor bastante estudado, devido à sua rápida e eficiente atuação na ativação dos sistemas de defesa das plantas, em baixas dosagens, além de ser um possível sinalizador durante o processo de indução de proteção sistêmica (Klessing, 1994; Ryals et al., 1996). Assim sendo, diversos estudos visando desvendar a sua participação na ativação do sistema de defesa das plantas vem sendo conduzidos, além do que o mesmo já é reconhecido como um indutor de proteção para as culturas de fumo, pepino e trigo, onde o induz proteção sistêmica inespecífica (Ye et al., 1989; Rasmussen et al., 1991; Palva et al., 1994; Seah et al., 1996; Fought \& Kuc, 1996).

Molina et al. (1998) demonstraram que o uso dos fungicidas metalaxyil, fosetil alumínio e hidróxido de cobre, quando aplicados em Arabidopsis, combinados com o indutor de proteção benzothidiazol (produto comercial - Bion), apresentaram efeitos sinergísticos no controle de Phytophthora parasitica. Benhamou \& Bélanger (1998) demonstraram também que o uso de benzothidiazol pode induzir a rápida formação de caloses em plantas de tomateiro, além da ativação de mecanismos secundários como polimerização de fenóis pré-existentes e síntese de novos compostos fenólicos, bem como sua deposição e infiltração em pontos estratégicos, como por exemplo, próximos a parede celular e nos espaços intercelulares.

$\mathrm{O}$ ácido 2,6 dicloronicotínico é outro indutor que vem merecendo destaque na indução de proteção de plantas a fitopatógenos e como um possível sinalizador do processo de ativação de defesa em plantas (Dann \& Deverall, 1995). Hijwegen \& Veerhaar (1994) obtiveram proteção de plantas de pepino a oídio pela aplicação do ácido nicotínico, o que resultou no aumento de calose e lignina. Na mesma linha, Newel et al. (1993) obtiveram bons resultados na indução de proteção sistêmica e no controle da bactéria $P$. syrungae pv. lachrymans. 
Hadwiger et al. (1994) e Benhamou et al. (1994) relatam também a quitosana, como um produto muito promissor no controle de fitopatógenos, visto que a mesma encontra-se intimamente relacionada com fatores de reconhecimento na interação patógeno hospedeiro, assim como o ácido acetil salicílico e ácido nicotínico. A quitosana é um derivado da quitina, que ocorre como constituinte da parede celular fúngica. A quitosana é obtida principalmente a partir da quitina de crustáceos, cascas de conchas e quitina de insetos (Hadwiger et al., 1988).

Leuba \& Stossel (1986) demonstraram que oligomeros de quitosana são capazes de agir diretamente sobre diversos fitopatógenos fúngicos inibindo o crescimento dos mesmos, além de serem potente elicitor de defesa em plantas. Benhamou et al (1998) obtiveram controle de Fusarium oxysporum f.sp. lycopersici em plantas de tomateiro pela aplicação foliar de quitosana, a qual induziu principalmente a formação de barreiras estruturais contra a penetração do patógeno. Wilson et al. (1994) também obtiveram bons resultados no controle de $B$. cinerea em frutos de tomate pelo uso de quitosana. Os mesmos pesquisadores demonstraram também a possibilidade do uso de luz U.V., inclusive em pós-colheita de frutos e vegetais, o que apresentou bons efeitos no controle de Penicillium sp. em citros, e $B$. cinerea em cenoura e pimentão, Monillinia fructicola em pêssego, Rhizopus stolonifer em tomate, além de controle de podridões de pós-colheita em maçãs.

É importante lembrar que a velocidade de expressão dos mecanismos de resistência pós-formados estruturais e bioquímicos são de vital importância no bloqueio ou não do patógeno (Morais, 1991). Marley \& Hillocks (1993) demonstraram que o feijão guandu teve sua expressão de resistência condicionada à produção de uma fitoalexina conhecida por cajanol. Os autores estudaram os cultivares ICP 9145 e Malawi, sendo que ambos apresentavam a produção deste composto, porém a velocidade de acúmulo da fitoalexina pelo cultivar ICP 9145 era aproximadamente 10 vezes mais rápida do que no cultivar Malawi. Através de inoculação de ambos os cultivares com o fungo Fusarium udum, foi observado que apenas o cultivar ICP 9145 apresentava resistência ao patógeno. 
Outra característica importante do processo de indução de resistência em plantas, é que o mesmo é inespecifico, podendo proteger as plantas contra qualquer fitopatógeno (Kuc, 1985). Dean \& Kuc (1986a) utilizando suspensões de C. lagenarium aplicado como elicitor em folhas cotiledonares de pepino, obtiveram proteção sistêmica a mais de 13 fitopatógenos, representados por fungos, vírus e bactérias.

A proteção induzida também depende do intervalo de tempo entre o tratamento inicial (elicitor) e a inoculação do patógeno, bem como do agente elicitor envolvido (Moraes, 1991; Silva, 1989). O efeito da proteção normalmente não é imediato, para a expressão de resistência como o observado para o caso de feijão guandu (Silva, 1989; Marley \& Hillocks, 1993). Esta dependência de tempo para a expressão da resistência irá determinar em parte a eficiência ou não do processo de proteção, pois quanto mais rápido a planta defender-se do patógeno, maiores serão as chances de impedir que o patógeno estabeleça-se no hospedeiro causando a doença.

A concentração do elicitor para a proteção de plantas também pode afetar a ativação da resistência da planta. Caruso \& Kuc (1979) utilizando de C. lagenarium, como indutor de resistência em folhas de melão e melancia, através da aplicação de uma suspensão de $10^{3}$ conídios $/ \mathrm{ml}$, obtiveram controle de 90 e $95 \%$ respectivamente, para uma posterior infecção com o patógeno. Sendo que o aumento da concentração da suspensão elicitora para $10^{7} \operatorname{conidios} / \mathrm{ml}$, provocou a redução do efeito protetor, o qual foi reduzido em 35 e $13 \%$, respectivamente.

A duração do efeito protetor pode ser duradouro ou temporário. Ross (1961) obteve indução de resistência sistêmica em fumo até 7 dias após a elicitação. Kuc \& Richmond (1977) obtiveram proteção sistêmica por 4-5 semanas em plantas de abóbora contra C. lagenarium. Roveratti et al. (1987) e Roveratti (1989) obtiveram também proteção sistêmica à $H$. vastatrix em cafeeiros, onde o efeito protetor mantevese viável durante 4-5 semanas. Lopez (1991) demonstrou que a proteção de plantas de sorgo era efetiva por um período de 7 dias contra o patógeno $C$. graminicola, através do uso de S. cerevisiae, como indutor de proteção. 
Jenns e Kuc (1979) e Dean \& Kuc (1986a,b) destacam também a possibilidade da transmissão da proteção induzida através de enxertia. Os autores sugeriram que um "sinal" químico é produzido no local de indução e que este sinal seria translocado para os demais tecidos conferindo a proteção.

De acordo com Moraes (1991) o processo de indução de proteção envolve a ativação de processos bioquímicos. Visto que a resposta de proteção irá envolver a síntese e o movimento de metabólitos, e que estes são originários de processos que requerem energia, supõem-se que a luz deva se constituir em importante fator envolvido em alguns processos de proteção. Lozano \& Sequeira (1970) utilizandose de células de $P$. solanacearum inativadas termicamente e de $P$. solanacearum virulentas, aplicadas em folhas de fumo, observaram que a presença de luz era necessária para a manifestação da resistência induzida. Porém, Carrol \& Lukezic (1972) obtiveram resultados contrários à influência da luz na proteção de folhas de plantas de alfafa tratadas com mutantes de Corynebacterium insidiosum. Os autores evidenciaram maior resistência aos isolados virulentos, quando as plantas foram mantidas por $24 \mathrm{~h}$ no escuro antes da inoculação do patógeno.

Klement \& Goodman (1968) demonstraram também a sensibilidade do processo de indução de resistência à temperatura. Foram utilizadas plantas de fumo crescidas à 20,24 e $30^{\circ} \mathrm{C}$, sendo procedidas então inoculações com o vírus do mosaico do fumo. Os resultados evidenciaram lesões locais como reação de resistência apenas para as plantas crescidas à 20 e $24^{\circ} \mathrm{C}$, mas não naquelas mantidas à $30^{\circ} \mathrm{C}$. Elliston et al. (1977) também demonstraram perda da eficiência da resistência induzida em plantas de feijão à C. lindemuthiamum e a C. lagenarium, quando as plantas foram mantidas à $37^{\circ} \mathrm{C}$.

\subsubsection{Indução de resistência local ou sistêmica}

A proteção de plantas pode ocorrer de dois modos distintos: local ou sistemicamente. A proteção local tem como característica o controle do patógeno no sítio onde o agente elicitor foi aplicado. 
Ouchi et al. (1976) evidenciaram proteção local em plantas de pepino a Erisyphe graminis, onde a indução foi obtida apenas nos pontos de aplicação do inóculo. Pascholati et al. (1986) através do tratamento de folhas de plantas de melão com $H$. carbonum ou $M$. melonis inativada termicamente utilizados como indutores contra $M$. melonis, não demonstraram proteção a distância do ponto de aplicação dos agentes indutores, caracterizando assim uma proteção do tipo localizada. Por sua vez, Silva (1989) obteve apenas proteção local contra C. graminicola em milho, quando utilizou como elicitor a levedura $S$. cerevisiae.

Postma \& Luttikholt (1996) obtiveram proteção de plantas de craveiro ao patógeno $F$. oxysporum f. sp. dianthi, pela inoculação prévia das plantas com um isolado de $F$. oxysporum não patogênico, onde os autores sugeriram, entre os possíveis efeitos, a indução de proteção local, além de um possível efeito antagônico pela competição por espaço e nutrientes por parte do isolado não patogênico.

Na mesma linha Fuchs et al. (1997) obtiveram indução de proteção em tomateiros pelo uso de um isolado não patogennico de $F$. oxysporum, em plantas inoculadas com o patógeno $F$. oxysporum f. sp. lycopersici, onde foi observado aumento nas atividades de quitinase, $\beta-1,3$ glucanase e $\beta-1-4$ glucosidase, além de possíveis efeitos de competição por espaço e nutrientes, como ferro. Nesse trabalho os autores fazem considerações sobre o uso combinado da resistência induzida e do controle biológico para o aumento da proteção das plantas de tomateiro.

A proteção sistêmica é caracterizada quando a mesma ocorre no hospedeiro em locais distantes ao da aplicação do elicitor (Silva, 1989). Roveratti et al. (1987) e Roveratti (1989) demonstraram que a ferrugem do cafeeiro pode ser controlada através do uso de indutores como Bacillus thuringiensis, S. cereviseae ("Fermento Biológico Fresco Fleischmann"), X. campestris pv. manihotis e outros. Os indutores conferiram resistência do tipo sistêmica à ferrugem, sendo que o efeito de proteção foi possível ser observado nas direções ascendentes e descendentes, a partir do ponto de aplicação dos elicitores. 
Por sua vez, Hoffland et al. (1996) obtiveram indução de resistência sistêmica contra $F$. oxysporum f. sp. raphani, pela indução de proteínas-RP $\left(\begin{array}{ll}\beta & 1,3\end{array}\right.$ glucanases, quitinases, etc), além de controle de Alternaria brassicicola e de $F$. oxysporum em rabanete pelo uso da rizobactéria promotora de crescimento $P$. fluorescens. Porém, os autores não conseguiram proteção a $R$ solani, para o qual o rabanete é altamente susceptivel. Esses pesquisadores sugerem que a indução de proteção sistêmica somente é possivel quando da existência de um nível básico de resistência genética. Por outro lado, a proteção sistêmica obtida pelo uso de $P$. fluorescens não apresentou reação alguma de hipersensibilidade, ao contrário do uso de P. syringae para as mesmas plantas de rabanete, em discordância ao fato da hipersensibilidade estar relacionada diretamente a este evento de indução de proteção sistêmica, conforme descrito por Dietrich et al. (1994) e Greenberg et al. (1994).

Guedes et al. (1980) demonstraram que a indução de proteção em pepino contra o patógeno $C$. lagenarium era mais evidente em folhas de localizadas acima da folha induzida do que nas folhas que estavam abaixo do local de indução ou nos próprios sítios de aplicação do indutor.

Bach (1997) utilizando goma xantana com o agente indutor em plantas de trigo, obteve indução sistêmica a Bipolaris bicolor, Bipolaris sorokiniana e Dreschelera tritici-repentis, onde a proteção obtida foi da ordem de $95 \%$ a $97 \%$.

$\mathrm{Na}$ mesma linha, Romeiro \& Kimura (1997) prepararam extratos purificados de lipopolissacarídeos, exopolissacarídeos, glicoproteínas capsulares e do envelope celular a partir de $X$. campestris pv. vesicatoria. A infiltração destes extratos no mesófilo foliar induziu proteção em pimentão contra a mesma bactéria que deu origem aos extratos, sendo observada a elicitação de fitoalexinas, apenas quando da utilização dos exopolissacarídeos bacterianos obtidos da goma xantana bacteriana.

Os trabalhos na linha de indução de proteção de plantas têm obtido cada vez maior destaque na área de pesquisa de novos produtos e em especial a proteção sistêmica a fitopatógenos. 
Nesta linha de pesquisa, Baillieul et al. (1995) isolaram uma glicoproteína de Phytophthora megasperma, a qual quando aplicada em plantas de fumo, foi capaz de induzir a ocorrència de reação de hipersensíbilidade nos pontos de inoculação do vírus TMV. Após algumas horas, obteve também proteção sistêmica, além do aumento da atividade das vias metabólicas de fenilpropanóides e sesquiterpenóides, bem como da ativação de gens de expressão para a biossíntese de proteínas-RP.

Benhamou et al. (1994) aplicaram quitosana em sementes de tomate, através de processo de peletização, e observaram a ocorrência de proteção sistêmica nas plantas oriundas de sementes tratadas contra podridão de raízes causadas por $F$. lycopersicum f. sp. radicis-lycopersici.

Leeman et al. (1996a,b) obtiveram controle da murcha de rabanete, causada por $F$. oxysporum, utilizando-se de $P$. fluorescens, onde os mesmos demonstraram que a bactéria controlava o patógeno pela produção de sideróforos, além de induzir resistência sistêmica.

\subsubsection{Indução de suscetibilidade}

O tratamento de plantas com supostos indutores de resistência, às vezes pode provocar efeito contrário à resistência, ou seja, pode ocasionar a supressão da resistência, fenômeno este chamado de suscetibilidade induzida (Ouchi, 1983). Pascholati \& Nicholson (1983) e Pascholati et al. (1985) utilizando Helminthosporium maydis em plantas de milho suscetiveis e resistentes a Helminthosporium carbonum, tornaram plantas resistentes em suscetíveis ao $H$. carbomım, quando previamente inoculadas com H. maydis.

A suscetibilidade induzida provavelmente está relacionada à capacidade de alguns patógenos impedirem a ativação dos mecanismos de resistência das plantas, pelo interrompimento do processo de reconhecimento. 
Esse processo pode ser feito através da produção por parte do patógeno de polissacarideos extracelulares de cápsulas, produção de enzimas e ou toxinas extracelulares, as quais irão interferir diretamente na permeabilidade da membrana plasmática ou outras atividades celulares como supressores, os quais interferem no processo de reconhecimento, através do condicionamento celular em direção à resistência.

O termo supressor de resistència pode ser definido como determinantes de patogenicidade especifica, os quais, ao contrário dos elicitores, inibem ou retardam a resposta de defesa vegetal, podendo atuar como indutores de susceptibilidade ou acessibilidade dos patógenos às plantas, tornando as mesmas susceptíveis a patógenos virulentos bem como os avirulentos (Shiraishi et al., 1997). Os supressores também não apresentam efeito fitotóxico aparente, são produzidos pelos patógenos no sitio de infecção, atuando na supressão da resistência e na indução de susceptibilidade local, sendo específicos em relação ao hospedeiro (Shiraishi et al., 1997). Entre as moléculas caracterizadas e com efeito supressor, temos as glucanas, fosfoglucanas, glicopepitídeos, glicoproteínas, peptídeos e oligossacarideos (Basse \& Boller, 1992; Shiraishi et. al. 1997)

\subsection{Controle biológico}

Se tomarmos como base que as doenças das plantas são oriundas de um desequilibrio da microflora benéfica anteriormente associada à planta, e a maneira que os tratos culturais são realizados na agricultura moderna, onde a falta de critérios para a realização do controle químico contribuem ainda mais para aumentar o desequilibrio microbiano, além de que os fitopatógenos recebem continuamente uma pressão de seleção a cada controle químico realizado. E a cada aplicação de defensivos, eliminamos não somente os fitopatógenos, mas também microrganismos benéficos (Tokeshi, 1991). 
E a cada nova aplicação de defensivos, os fitopatógenos apresentam-se mais resistentes e aptos à sobrevivência que os não patógenos, os quais são facilmente eliminados. Após realizarmos um controle químico, propiciamos a eliminação de grande parte da microflora existente, facilitando assim o desenvolvimento dos patógenos (Baker, 1994; Boland, 1990; Tokeshi, 1991;1997).

Visando o restabelecimento destas relações hospedeiro e microflora benéfica, surgiram estudos procurando encontrar microrganismos antagônicos aos mais variados patógenos para o controle de doenças, dando origem então ao que conhecemos por controle biológico de doenças de plantas. Cook \& Baker (1983) definiram o controle biológico de doenças de plantas como a redução do potencial de inóculo e ou patogenicidade, pelo uso de um ou mais organismos, exceto o homem.

O mecanismo de ação dos agentes de biocontrole, pode ser ilustrado através de três métodos básicos de controle: antibiose, parasitismo e competição. A antibiose baseia-se na produção de substâncias com efeito fungicida ou fungistática, bactericida ou bacteriostática e nematicida. Estas substâncias são produzidas pelos organismos antagonistas como um mecanismo de proteção à sua sobrevivência diante dos demais microrganismos existentes na microflora que ocupa (Luz, 1993).

Entre os microrganismos produtores de antibióticos e utilizados no controle biológico, temos o Bacillus subtilis (Sanhueza, 1987). Essa bactéria produz uma enorme gama de antibióticos, tais como micosubtilina, bacillomicina (Karel \& Roach, 1951) bacilizina e funginicina (Loeffler et al. 1986; Tschen, 1987) e bulbiformina (Vasudeva et al., 1958) os quais exibem a capacidade de inibir uma vasta gama de bactérias e fungos fitopatogênicos (Dunleavy, 1955).

Por sua vez, os fungos do gènero Trichoderma também produzem antibióticos de vários tipos, porém nem todas as espécies do fungo tem ação antibiótica, pois se valem de outros mecanismos no biocontrole das doenças de plantas (Baker, 1994; Sanhueza, 1991; Elad.et al., 1994a; Elad.et al., 1994b). 
O Gliocladium roseum é um fungo que tem sido bastante estudado visando a sua utilização em controle biológico, devido à capacidade de sobrevivência e efetividade no controle de fitopatógenos. Este fungo produz substâncias com elevado poder antibiótico, sendo juntamente com o Trichoderma, um dos fungos antagônicos mais estudados atualmente visando o controle biológico de doenças fúngicas ( $\mathrm{Yu} \&$ Sutton, 1999).

Para o controle de bactérias, temos um dos mais famosos produtos de uso comercial para o controle da galha da coroa das rosaceas que é derivado de bactérias do gênero Agrobacterium. Neste caso, a bactéria A. radiobacter produz uma substância antibiótica chamada bactericina, que é capaz de controlar a A.tumefaciens (Kerr, 1980).

O mecanismo de parasitismo ou hiperparasitismo, exercido pelos microrganismos, consiste na degradação da parede celular ou estruturas de resistência dos fungos fitopatogênicos, com posterior penetração no fungo e absorção do conteúdo celular (Chet, 1987; Chet et al., 1990). Elad et al. (1982) demonstraram que as enzimas celulase e $\beta-1,3$ glucanase são produzidas por Trichoderma spp, quando o fungo hiperparasita a parede celular de Pythium sp e que enzimas como quitinase e $\beta-1,3$ glucanase são produzidas quando o fungo é colocado em presença de $R$. solani e $S$. rolfsii.

No entanto, podemos encontrar um microrganismo com mais de um modo de ação ou habilidade de competição aos demais. Tronsmo \& Dennis (1977) demonstraram que o fungo Trichoderma $\mathrm{sp}$. atua no controle de $B$. cinerea em morango tanto pela ação hiperparasitária, como pela produção de substâncias antibióticas, além da competição com os demais microrganismos. Dessa maneira, o antagonista dificulta o início e a ocorrência do processo infeccioso por parte dos patógenos, onde os mesmos, devido à competição, ficam restritos à forma saprofítica de sobrevivência, até que alguma alteração neste equilíbrio permita o desencadeamento do processo infeccioso, resultando em doença (Tokeshi, 1991). 
A competição é praticamente o mecanismo que coordena a existência de todos os demais mecanismos de biocontrole, pois o que leva um microrganismo a controlar outro, é exatamente a necessidade de sobrevivència em determinado habitat, e esta competição confere muitas vezes o equilibrio entre a população de patógenos e não patógenos (Cook \& Baker, 1993).

Reis $(1987 ; 1989)$ cita o fenômeno conhecido por declínio do mal do pé do trigo causado por Gaumannomyces graminis var. tritici, onde a doença surge no $2^{\circ}$ ou $3^{\circ}$ ano de cultivo, aumenta a severidade nos anos subsequentes, e com o passar dos anos diminui até estabilizar-se em níveis que não comprometem economicamente a cultura.

Louvet et al. (1981) e Rovira \& Wildermuth (1981) também observaram fenômeno semelhante ao do G. graminis em trigo, onde em alguns solos foram encontradas altas populações de $F$. roseum, $V$. albo-atrum, $F$. solani, $R$. solani e $P$. cinnamomi, e mesmo assim as culturas presentes nestes locais não apresentavam danos econômicos. O fato acima deu origem ao nome de solos supressivos para este tipo de ocorrència. A única diferença observada em relação a um solo aparentemente sem este efeito supressor era a população microbiana existente. Para os solos supressivos, a população de microrganismos era extremamente elevada, o que leva a supor que devido à competição com a microflora nativa, estes patógenos atuem como habitantes naturais do solo e com baixa virulência, pois isto poderia ocasionar perda da capacidade competitiva e conseqüente morte dos mesmos.

O fenômeno do controle biológico através da competição envolve principalmente a disputa por nutrientes e espaço. A velocidade de crescimento, bem como a eficiência na absorção de determinadas formas de carbono, nitrogênio e outros nutrientes minerais determinam a sobrevivência dos microrganismos em alguns ambientes, assim como a sucessão de populações (Paulitz, 1990; Campbell, 1994; Mello, 1996). Leite et al. (1995) citam também a existência de compostos voláteis produzidos tanto por microrganismos quanto pelas plantas, os quais podem atuar tanto inibindo como estímulando a germinação e o desenvolvimento de patógenos fúngicos. 
Esse é um importante mecanismo de controle dos fungos de solo ou microrganismos de parte aérea como C. graminicola, onde foi observada a inibição e a morte dos conidios do patógeno pela exposição dos mesmos a vapores de ácido acético, em condições de laboratório.

Leong (1986) demonstrou a existência de um composto denominado de sideróforo, produzido por $P$. fluorescens, o qual apresenta um efeito quelante por $\mathrm{Fe}^{+3} . \mathrm{O}$ sideróforo torna o ferro indisponivel aos demais microrganismos que não disponham dos mecanismos de quelatização. E mais recentemente, o conceito de rizobactérias ou bactérias promotoras de crescimento, entre elas a $P$. fluorescens, tem recebido uma especial atenção, devido as mesmas sobreviverem naturalmente na região da rizosfera ou endofiticamente nas plantas, além de promoverem um maior desenvolvimento das plantas, conferindo proteção as plantas por meio de competição, antibiose e produção de sideróforos (Fravel, 1988; Weller, 1988; Duijff et al., 1993) além de elicitarem proteção em plantas (Piga et al., 1997).

Os relatos de controle de doenças de plantas pela elicitação de defesa combinados ou não com mecanismos de controle biológico, tais como competição por nutrientes, siderófos, espaço e antibiose, são encontrados para uma variada gama de fitopatógenos, entre os quais $P$. syringae pv. lachrymans em pepino (Liu et al., 1995a, Wei et al., 1996) C. orbiculare em pepino (Liu et al., 1995b; Wei et al., 1996) R. solani em feijão e pepino (Kataria et al., 1997) F. oxysporum f. sp. radicis-lycopersici (Piga et al, 1997) e vírus do mosaico do pepino (cucumovírus-CMV) em plantas de pepino e tomate (Raupach et al., 1996).

Leeman et al. (1996a,b) observaram uma redução do efeito elicitor de $P$. fluorescens em plantas de tomate, nos tratamentos onde foram adicionadas maiores concentrações de ferro, sendo uma das possiveis hipóteses a redução na produção de pseudobactinas (sideróforos). Os autores sugerem que a ação das pseudobactinas deve estar mais relacionada à ativação de mecanismos de indução de proteção sistêmica, do que à redução na disponibilidade de ferro para os demais microrganismos, e talvez este mecanismo de quelatização de ferro nem sequer atue de modo satisfatório para controle de fitopatógenos. 
Lockwood (1989) faz uma séria crítica ao controle biológico utilizado atualmente, ou seja, o mesmo discorda do uso de apenas um único microrganismo no processo de biocontrole. Na natureza, o que ocorre é um interação de várias populações microbianas, sendo que muitas vezes os organismos envolvidos não passam de saprófitas, e que de maneira direta competem por espaço e nutrientes no solo, rizosfera e filoplano.

Windels \& Lindow (1985) relatam o caso do CBD ("coffee berry disease") do cafeeiro causado por C. coffeamum, e ainda inexistente no Brasil. Nos países onde a doença ocorre, foi observado que as aplicações de fungicidas, em especial os cúpricos, aumentavam a incidência e severidade da doença. Esse fato foi explicado com base na observação de que o controle biológico de Colletotrichum era devido principalmente à competição por nutrientes (em especial açúcares) com a microflora natural (leveduras) das folhas. As bactérias e leveduras, habitantes naturais do filoplano e rizosfera, estão entre os principais microrganismos que atuam na redução da germinação conidial pela competição por nutrientes (Blakeman \& Fokema, 1982).

As leveduras têm sido alvo de estudos também para o controle de fitopatógenos em pós-colheita de frutos principalmente, visando a redução dos exsudatos açúcarados decorrentes do processo de maturação e senescência dos frutos, os quais consitituem-se em fonte de alimento e estímulo para a ação de fitopatógenos (Cook et al., 1999). Tokeshi (1991) afirma que somente retornando a um equilíbrio da nutrição mineral de plantas, além do restabelecimento de uma microflora estável e competidora semelhante às existentes no passado ou nos centros de origem das plantas, é que poderemos obter resultados satisfatórios no controle biológico de doenças. Deste modo, o manejo integrado de todos os fatores de controle são de vital importância para a manutenção e retorno do equilíbrio biológico perdido.

$\mathrm{O}$ uso de microrganismos antagònicos vivos constitui a maior modalidade de controle biológico, porém nem sempre efetivo, pois estes microrganismos muitas vezes são retirados de uma condição de sobrevivência e levados a outra completamente diferente, quer seja em relação à ambiente e a hospedeiros (Baker, 1994). 
As plantas exercem fator essencial à nutrição e, portanto, à sobrevivência dos competidores, devido às características de exsudatos foliares e radiculares, as quais irão determinar a nutrição do organismo competidor introduzido, além da adaptação ao novo ambiente, bem como a capacidade de competição com os demais microrganismos nativos pré-existentes (Tokeshi, 1991; Cook \& Baker 1983; Elad et al., 1994a; Kloepper, 1996). Deste modo, o uso de microrganismos com boa capacidade competidora, que ofereçam bom controle do patógeno desejado, além de serem capazes de sobreviver junto ao hospedeiro e sem necessidade de inoculações sucessivas para o restabelecimento das populações do microrganismo antagônico, tem sido preferidos para o controle biológico (Kloepper, 1996).

Atualmente, as rizobactérias têm sido bastante estudadas devido a estas características e em especial a $P$. fluorescens (Duijff et al., 1993; Raaijmakers, et al., 1995; Kloepper, 1996; Kloepper et al., 1997; Krishnamurthy \& Gnanamanickam, 1997).

Muitas das substâncias antibióticas produzidas por microrganismos têm sido sintetizadas para a produção de fungicidas ou bactericidas de largo espectro e eficiência no controle de fitopatógenos (Cook \& Baker 1983). O fungo Strobilurus tenacellus é um destes recentes usos de substâncias produzidas por um fungo e sintetizadas em um composto químico para o controle de doenças fúngicas em plantas.

A molécula kresoxim-metil derivada das strobirulinas produzidas por este fungo foi modificada químicamente visando conferir melhores propriedades de absorção sistêmica pelas plantas bem como estabilidade da molécula. Sendo que o produto final, a strobirulina, apresenta um bom controle sobre uma vasta gama de patógenos fúngicos, podendo inclusive inibir a esporulação dos mesmos (Ypema \& Gold, 1999).

Neste caso, o controle biológico serviu apenas como uma ferramenta no desenvolvimento de uma nova molécula, e com um novo modo de ação, o que não deixa de ser algo interessante em termos de controle de doenças de plantas, pois o efeito do produto original foi potencializado pela modificação e sintese de uma nova molécula. 


\subsection{Patossistemas}

\subsubsection{Sorgo - Exserohilum turcicum}

A mancha foliar causada por E. turcicum é uma das principais doenças que afeta a cultura do sorgo, distribuída praticamente por todas as regiões produtoras de sorgo, onde os prejuízos atingem até 50\% da produção (Coelho, 1983; Ferreira, 1984; Frederiksen, 1991). Os sintomas caracterizam-se pelo surgimento de pequenas manchas descoloridas nas folhas e que evoluem para lesões do tipo necróticas, de formato elipsoidal com centro palha, acompanhadas de um halo avermelhado que delimita as lesões. Com a evolução da doença, as lesões tendem a coalescer tomando grandes áreas do limbo foliar, o que acaba por acarretar a seca das folhas afetadas (Frederiksen, 1991).

Os sintomas iniciam em geral pelas folhas da base, ou seja as folhas mais velhas e depois evoluem para as folhas do topo, até atingirem a folha bandeira. $\mathrm{O}$ patógeno não danifica os grãos de sorgo, porém, quebras na produção podem ser sentidas devido à redução da área fotossintética pela seca das folhas (Esteves, 1984; Frederiksen, 1991).

O patógeno E. turcicum (Pass.), corresponde em sua fase perfeita ao fungo ascomiceto Trichometasphaeria turcica Luttrell, sendo sua fase sexual raramente encontrada na natureza (Frederiksen, 1991; Muchovej et al., 1988; Alcorn, 1988). Os conídios medem 10-29 por 28-153 $\mu \mathrm{m}$, sendo os mesmos produzidos isoladamente em cada conidióforo, sem a formação de cadeias. Apresentam segmentação que varia de 3 a 8, e disseminação feita principalmente pelo vento, além da possibilidade de transmissão via semente (Balmer, 1980; Frederiksen, 1991; Muchovej et al., 1988).

As condições ideais para a ocorrência de infecção são temperatura na faixa de 20 a $25^{\circ} \mathrm{C}$ e umidade relativa acima de $90 \%$ (Frederiksen, 1991; Lasca et al., 1986). A condição de escuro é ideal para que ocorra a infecção, pois a luz exerce fator negativo na germinação e esporulação do patógeno, assim como níveis elevados de açúcares na folha do hospedeiro. 
Por esse motivo, o patógeno é conhecido como "low sugar" ou fungo não açucareiro. A penetração do patógeno é feita via direta ou indireta, através dos estômatos (Balass \& Levy, 1984; Levy \& Tal, 1985; Levy \& Cohen, 1981, 1984).

A sobrevivência do patógeno de um ano para outro ocorre em restos de cultura infectados pelo fungo, sendo que na ausência de material infectado, o patógeno não é capaz de sobreviver de forma saprofítica no solo (Sheere \& Luke, 1983). Outra possibilidade da permanència do patógeno de um ano para outro é através de plantas hospedeiras, como por exemplo o Sorghum halepense (capim massambará), ou mesmo em soca da cultura de sorgo ou plantas oriundas de restos de sementes que ficam no campo após a colheita das plantas (Levy, 1984).

O controle da mancha foliar é feito basicamente pelo uso de variedades resistentes, devido a existência de muitas raças do patógeno e aos programas de melhoramento, de uma maneira geral, serem direcionados para a resistência do tipo vertical (Coelho, 1983; Ferreira, 1984; Ullstrup, 1970; Moura \& Silva, 1981; Misra, 1989; Prabhu \& Morais, 1993; Bleicher et al., 1993). Assim sendo, o processo de seleção passa a ser contínuo e de curta duração (Camargo \& Bergamin Filho, 1995).

$\mathrm{O}$ uso do controle químico mostrou-se como alternativa, quando não é possivel a obtenção de um controle satisfatório com o melhoramento. $O$ uso de fungicidas inibidores da biossintese de esteróis, tal como o propiconazole tem demonstrado grande eficiência no controle de E. turcicum (Bowen \& Pedersen, 1988). Porém, alguns problemas como aplicação e custos, além de problemas de resistência ao produto podem inviabilizar o seu uso. Nesse caso, mostra-se necessária a aplicação de outras medidas de controle conjuntamente ao controle químico (Kimati, 1995; Forcelini, 1994).

\subsubsection{Sorgo - Colletotrichum sublineolum}

A antracnose é considerada a principal doença do sorgo no Brasil, sendo uma das mais importantes doenças dessa gramínea em todas as regiões produtoras no mundo (Frederiksen, 1991; Fernandes \& Schaffert, 1978; Casela \& ferreira, 1988a,b). 
Casela \& Ferreira (1987a) obtiveram, através de inoculações artificiais, perdas de $88 \%$ no rendimento de grãos, $23,9 \%$ no peso de 100 sementes e $54,3 \%$ na produção por hectare. Casela \& Frederiksen (1993b) e Ali \& Warren (1987) relataram prejuízos acima de $50 \%$ na produção, quando apenas as folhas de cultivares suscetiveis foram afetadas pelo patógeno.

O patógeno caracteriza-se por afetar folhas, caule, haste floral, flores e sementes de sorgo em qualquer idade. Os sintomas em folhas se iniciam por pequenas lesões circulares ou elípticas de coloração arroxeada e que com a evolução da doença coalescem tomando grandes áreas do limbo foliar. O centro das lesões adquirem tonalidade palha com o envelhecimento, e os sintomas de necrose foliar avançam até ocasionarem a seca das folhas afetadas (Frederiksen, 1991). A doença afeta severamente também as hastes florais e o caule das plantas, sendo os sintomas semelhantes aos que ocorrem nas folhas, porém, acompanhado de podridão dos pontos atacados, onde em corte observa-se um avermelhamento dos tecidos infectados.

Em geral, as podridões de caule permitem $o$ ataque de outros fitopatógenos, quase sempre levando à morte da planta. Os sintomas nas hastes florais levam desde a quebra das hastes até a interrupção do fluxo da seiva, acarretando o não enchimento dos grãos (Frederiksen, 1991; Casela \& Frederiksen, 1993a).

Os efeitos do patógeno nas flores ou grãos são muito severos, pois afetam diretamente a produção, além de prejudicarem a qualidade de grãos e ou sementes (Cardwell, 1989; Lasca et al., 1986).

A antracnose do sorgo é causada pelo fungo C. graminicola Ces. G. W Wils., que na fase perfeita corresponde a Glomerella graminicola, produz conídios isolados e simples (Frederiksen, 1991; Nicholson, 1992). Os esporos do C. graminicola são produzidos em associação a uma matriz mucilaginosa solúvel em água. Em condições de baixa umidade relativa (abaixo de 45\%), a matriz torna-se seca e pulverulenta em $48 \mathrm{~h}$, o que permite também a possibilidade da disseminação aérea do patógeno (Nicholson \& Moraes, 1980). 
A importância da matriz mucilaginosa está no efeito da mesma conferir ao patógeno proteção a dissecação dos conídios e maior sobrevivência dos mesmos. Com a remoção da matriz, via água, os conidios tem sua viabilidade reduzida para $24 \mathrm{~h}$, sendo completamente perdida em $48 \mathrm{~h}$.

A matriz também tem efeito inibitório na germinação dos conídios, impedindo que todos germinem de uma única vez, além de conferir importante papel na penetração do patógeno no hospedeiro, devido conter enzimas do tipo invertase, $\beta$ glucosidase, cutinase, esterases, DNAses, RNAses, lacase, protease e fosfatase alcalina (Nicholson \& Moraes, 1980; Nicholson, 1992; Pascholati et al., 1993; Ramadoss et al., 1985).

As condições ideais para que ocorra a penetração envolvem temperaturas na faixa de 22 à $30^{\circ} \mathrm{C}$, umidade relativa acima de $90 \%$, e a presença de água livre (Frederiksen, 1991; Leonard \& Thompson, 1976; Nicholson \& Warren, 1976; Nicholson, 1992). Nestas condições, as primeiras lesões do patógeno podem ser observadas de 3 a 5 dias após as inoculações, sendo que as primeiras manchas cloróticas podem ser observadas 24 a $48 \mathrm{~h}$.

A disseminação do patógeno é feita basicamente por sementes infectadas, as quais podem levar o patógeno à grandes distâncias e novas áreas geográficas (Cardwell, 1989; Chaudhary \& Mathur, 1979; Siddiqui et al., 1983; Prasad, et al., 1985; Lasca, et al., 1986). Por sua vez, a disseminação do patógeno de uma planta para outra, dentro de uma mesma cultura ou culturas próximas, ocorre principalmente devido às condições de alta umidade relativa, em geral chuvas, que solubilizam a matriz mucilaginosa. Quando as chuvas são acompanhadas de vento, a disseminação torna-se mais eficiente a maiores distâncias (Amorim, 1995; Nicholson, 1992; Frederiksen, 1991).

A sobrevivência do patógeno de um ano para outro ocorre em geral pela presença de plantas de sorgo remanescentes e infectadas, plantas daninhas hospedeiras ou restos de cultura infectadas, folhas, sementes e ou panícula, caule, etc.(Frederiksen, 1991; Lipps, 1983). No solo, o patógeno perde sua viabilidade em pouco tempo (11 a 16 dias) (Vizvary \& Warren, 1981). 
Nakamura \& Fernandes (1982) relataram pela primeira vez, a ocorrência de raças fisiológicas de $C$. graminicola em sorgo. Atualmente, diversas pesquisas procuram caracterizar e diferenciar raças de C. graminicola, visando a obtenção de cultivares resistentes e fornecer suporte nos programas de melhoramento, visto que a resistência genética é um dos meios mais efícientes e baratos para o controle da antracnose (Casela \& Frederiksen, 1994; Paiva, et al., 1990; Ferreira \& Casela, 1986; Ali, 1987). No Brasil, a totalidade dos trabalhos destinados a obtenção de resistência para o C. graminicola em sorgo são para a resistência do tipo vertical ou completa (Casela \& Ferreira, 1987b; Ferreira \& Warren, 1982; Casela \& Frederiksen, 1993a).

Isso leva a um contínuo programa de seleção devido à grande quantidade de raças fisiológicas existentes e descritas por diversos autores (Vanderplank, 1963, 1968; Prabhu \& Moraes, 1993) fato este que pode ser confirmado pelos trabalhos publicados sobre melhoramento a $C$. graminicola no Brasil que vão de 1982 até o presente momento.

Recentemente, através de análise da sequência de rDNA, foi verificada uma diferença entre o C. graminicola isolado de sorgo e o de milho, onde para o isolado de sorgo foi sugerida a reclassificação para $C$. sublineorum e mantido o nome $C$. graminicola para os isolados de milho (Sherriff et al., 1995).

\subsubsection{Maracujá - Xanthomonas campestris pv. passiflora}

Os sintomas da bactéria manifestam-se de duas formas distintas: a) lesões locais, as quais são caracterizadas por distribuição bastante desuniforme no limbo foliar e aparência grosseiramente arredondada, bem delimitadas, raramente de formato angular e com pequeno halo clorótico. Sendo a lesão de aparência oleosa, a mesma é facilmente visualizada em contraste com a luz.; b) Infecções sistêmicas - este tipo de infecção difere das locais por apresentar grandes áreas de tecido infectado, e não se restringir localmente nas células do ponto de infecção nas folhas, mas se alastrando através dos feixes vasculares para outras partes da planta como, peciolos, ramos e frutos (Pereira, 1968; Matta, 1982; Toledo, 1992). 
A mancha oleosa do maracujazeiro ou morte precoce do maracujazeiro foi encontrada pela primeira vez, ocorrendo na região de Araraquara, Estado de São Paulo, sendo o primeiro relato desta bactéria no continente americano (Pereira, 1968; Toledo, 1992). A bactéria apresenta forma de bastonetes curtos, que medem em média de $0,5 \times 1,5 \mu \mathrm{m}$, e com extremidades arredondadas. Os bastonetes geralmente ficam isolados aos pares, raramente em cadeias, possuem flagelo polar, no entanto exibindo pequena mobilidade. São bactérias do tipo gram negativas, apresentando cápsula e aeróbias restritas (Pereira, 1968). A penetração da bactéria no hospedeiro ocorre via aberturas naturais (estômatos, hidatódios, botão floral, etc..) ou por ferimentos, sendo necessária a presença de água livre na superficie foliar para que a infecção ocorra (Amorim, 1995).

As infecções bacterianas do tipo sistêmica, tendem a afetar toda a planta, sendo o controle da doença impossível de ser feito. Dessa maneira, o controle da mancha oleosa do maracujazeiro pode ser realizada com sucesso somente quando existirem apenas lesões do tipo local (Piccinin et al., 1995; Torres Filho \& Ponte, 1994).

Esta doença tem sido observada com maior severidade em regiões de temperaturas médias mais elevadas, constituindo-se em fator limitante de produção em regiõess de clima mais quente, e também propicias a cultura do maracujá (Torres filho \& Ponte, 1994; Piccinin et al., 1995). Além de que nestas condições os sintomas da bacteriose evoluem para a seca de folhas e ramos das plantas, assim como propicia o surgimento de infecções de C. gloeosporioides, outra importante doença do maracujazeiro (Francisco neto et al., 1994; Torres filho \& Ponte, 1994).

O controle da bactéria é feito de modo preventivo, evitando a chegada do patógeno nos locais de cultivo, através da aquisição de mudas sadias. Nas culturas onde a bactéria já se encontra instalada, a única alternativa é o uso de fungicidas cúpricos ou do grupo dos dithiocarbamatos (Zineb, Maneb, Thiram, etc), quando existirem apenas lesões locais (Torres Filho \& Ponte, 1994). Por sua vez, Romeiro \& Muchovej (1990) e Barbosa (1995) citam o uso de antibióticos para o controle da bactéria. 
Romeiro \& Muchovej (1990) utilizando de sulfato de streptomicina encontraram que o mesmo tem seu efeito melhorado para o controle da bactéria quando veiculado juntamente com lanolina, onde foi observado também uma redução significativa na proteção das plantas de maracujazeiro contra avanços nas infecções locais para sistêmicas.

Os antibióticos não são capazes de curar as plantas infectadas, sendo seu custo ainda elevado em relação aos fungicidas cúpricos, porém não propiciam o aparecimento de isolados resistentes.

\subsubsection{Vírus do mosaico do fumo (TMV)}

O TMV (tobacco mosaic virus) encontra-se distribuído por todas as regiões onde o fumo é cultivado. A redução da produção das plantas infectadas está por volta de $15 \%$, porém a facilidade com que este vírus é transmitido via mecânica e sua elevada incidência torna esta doença uma das mais importantes da cultura do fumo.

Além do fumo, esta doença já foi relatada para 199 espécies e 30 famílias, porém a principal fonte de inóculo são as solanáceas (tomate, pimentão, pimenta, jiló, maria pretinha, jurubeba, etc.) (Shew \& Lucas, 1991). As partículas virais do TMV são filamentosas e resistentes às altas temperaturas e apresentam tamanho de $18 \times 300 \mathrm{~nm}$ aproximadamente, tendo a capacidade de cristalização fora do hospedeiro, podendo assim permanecerem viáveis por muitos anos (Shew \& Lucas, 1991).

O TMV permanece viável durante anos nos restos de cultura do fumo, no fumo de corda ou cigarros, pólen, etc (Tokeshi \& Salgado, 1980). Sendo a transmissão por sementes relatadas para várias espécies de solanáceas, exceto para o fumo (Godoy \& Salgado, 1997). A transmissão por insetos ocorre de modo não persistente, principalmente por afideos, onde são relatadas mais de 60 espécies, porém este meio de transmissão é insignificante. Porém, a transmissão mecânica é o principal meio de disseminação da doença, a qual ocorre especialmente durante as operações de desbrota das plantas (Tokeshi \& Salgado, 1980; Godoy \& Salgado, 1997). 
Os sintomas da virose provocada por TMV em fumo podem surgir em qualquer idade do desenvolvimento das plantas, podendo variar um pouco em relação às estírpes do vírus presentes e da reação das variedades de fumo. Os sintomas observados geralmente são de redução na área foliar, acompanhada de rugosidade e má formação das folhas, que podem apresentarem-se mais afiladas e espessas. No limbo foliar, observamos a presença de áreas verde claras ao lado de áreas de verde normais, dando ao conjunto um aspecto de mosaico que dá o nome à doença. As plantas infectadas com o mosaico podem apresentar o dobro de nicotina que as plantas sadias de mesma variedade (Tokeshi \& Salgado, 1980).

O controle da doença é feito basicamente pelo controle das operações de limpeza e queima de restos culturais, poda controlada pela desinfecção das ferramentas de poda e "rouguing" de plantas infectadas. Existem ainda variedades resistentes, tais como Kentuchy 56 e 57, Vannor 48 e 50 e Turkish (WN), onde todas apresentam resitência do tipo hipersensibilidade, conferida pelo gen NN na forma homozigótica (Tokeshi \& Salgado, 1980).

O fumo tem sido considerado um patossistema clássico no estudo da ativação dos processos de defesa das plantas, como a indução de proteção sistêmica e a produção de proteínas-RP, por exemplo $\beta$-1,3-glucanases e quitinases (Bol \& Linthorst, 1995).

\subsection{Lentinula edodes (shiitake)}

O cogumelo comestível Lentimula edodes (Berkley) Pegler (1983) ou shiitake, é conhecido há aproximadamente 1.000 anos nos paises asiáticos e de origem do cogumelo (Singer, 1961; Przybylowicz \& Donoghue, 1990). Alguns autores ainda utilizam o nome de Lentimus edodes para denominar o cogumelo, porém, atualmente o nome cientifico mais aceito para classifica-lo é Lentimula edodes (Molina et al., 1992). 
O "shiitake" apresenta uma concentração média de proteínas de 10 à $20 \%$ de seu peso seco (Crisan \& Sands, 1978) contendo os 9 aminoácidos essenciais à nutrição humana e quantidades consideráveis de leucina e lisina, para os quais a maioria dos cereais apresenta deficiência (Chang, 1980). Além de 22,7\% de proteinas, das quais 80 à $87 \%$ com alta digestibilidade para o homem, apresentam 3,2\% de lipídeos, $10 \%$ de fibras e 4,7\% de cinzas (Prybylowicz \& Donoghue, 1990). O cogumelo contém também de 43 à $78 \%$ de carboidratos, 2,6 à $6,5 \%$ de minerais, sendo os principais elementos cálcio, fósforo, ferro, sódio e potássio (Crisan \& Sands, 1978).

O cogumelo também é rico em vitaminas do complexo B (Chang \& Miles, 1984; Jones, 1995) além de vitamina D, a qual encontra-se principalmente na forma de pró-vitamina D2 (ergosterol). Na presença de luz UV ou calor, a pró-vitamina D2 é convertida em vitamina D (Mizuno, 1995) porém nestas condições ocorre uma redução nos teores médios de vitaminas do complexo B, especialmente para niacina, riboflavina e tiamina (Takeuchi et al., 1994; Jones, 1995).

Além das propriedades nutricionais citadas, o cogumelo shiitake apresenta inumeras outras substâncias antimicrobinas e com efeito terapêutico ou medicinal. A importância e o uso do shiitake como produto terapêutico é conhecido desde a dinastia Ming (1.368-1.644), onde atribui-se ao shiitake relatos de aumento do vigor e energia das pessoas, além de efeito afrodisíaco (Ito, 1978). Diversos efeitos terapêuticos tem sido demonstrados para o cogumelo shiitake, além de purificação e identificação de diversos compostos de efeito medicinal, muitos destes já patenteados e comercializados.

Ikekawa et al. (1969) isolaram, a partir de extrato aquoso do corpo de frutificação do cogumelo, um polissacarídeo de configuração atômica helicoidal, com alto peso molecular, solúvel em água e formado por $\beta-1,6$ glucana, com ramificações $\beta$ 1,6 e $\beta-1,3$ glicopiranosídeo, o qual foi chamado de lentinan. Essa glucana está presente na parede celular do corpo de frutificação do cogumelo (lkekawa, 1969; Jones, 1995; Hobbs, 1996; Wasser \& Weis, 1999). 
Chihara et al. (1969) demonstraram, em ensaios com camundongos e sarcoma 180, a regressão de tumores pela injeção intraperitoneal do lentinan. Namba et al. (1987) obtiveram redução de tumores cancerígenos em ratos pela administração oral de corpos de frutificação desidratados e moídos do $L$. edodes, onde a redução dos tumores foi por volta de $87 \%$, sendo o efeito na redução dos tumores atribuído ao lentinan. Kanai et al. (1980) e Suzuki et al. (1994) demonstraram também que o lentinan age como um imunopotenciador combinado com sua atividade antimetástica, prevenindo o desenvolvimento ou regredindo carcinogenese dos tipos química e viral.

O uso de lentinan, quando associado a tratamentos como quimioterapia, radioderapia e outros tratamentos para o câncer, exerce um efeito sinergístico, potencializando os medicamentos empregados. Exibe atividade antiviral através da potencialização ou estímulo das defesas do hospedeiro. Irinoda et al. (1992) observaram o mesmo efeito potencializador das defesas do hospedeiro reduzindo o efeito do vírus da influeza, e Yoshida et al.(1988) obteve sucesso no controle do HIV (vírus da imunodeficência humana).

Jong \& Birmingham (1993) citam que o lentinan apresenta atividade antibacteriana para E. coli, Pseudomonas aureaginosa e Klebsiella pneumonia, além de efeito anti-fúngico para Candida albicans. No entanto, estes efeitos são provavelmente devido ao aumento da imunoproteção e não propriamente pela ação direta do lentinan sobre os microrganismos.

Fujii et al. (1978) utilizando-se de crescimento micelial do shiitake em resíduos de fabricação de uísque, obtiveram uma manana ligada a um pepitídeo denominada de KS-2, a qual também exibiu atividade antiviral contra o vírus da influenza em ratos, além de atividade antitumoral e indutora da produção de interferon. Porém, a atividade antiviral está provavelmente relacionada à uma restauração da resposta imune, não agindo diretamente sobre a partícula viral (Suzuki et al., 1979)

O LEM ("Lentimula edodes mycelia") é uma heteroglucanoproteína (glicoproteína ou $\beta$ glucana ligada a proteina), composta de galactose, xilose, arabinose, vitaminas do complexo B, especialmente vitaminas B1 (tiamina) e B2 (riboflavina), ergosterol, além de ácidos nucleicos e derivados (Breene, 1990). 
O LEM pode ser obtido a partir do extratos do micélio do cogumelo ou ainda da cultura líquida do crescimento micelial (Sugano et al., 1982). O LEM é obtido através do cultivo do micélio em meio de cultura líquido durante 80 a 120 dias à temperatura de 20 à $22^{\circ} \mathrm{C}$, seguida de secagem do micélio obtido, durante 50 à 60 horas à temperatura de 40 à $50^{\circ} \mathrm{C}$. Após esta etapa adiciona-se o micélio seco em água à $60^{\circ} \mathrm{C}$, e, em seguida, procede-se a liofilização da amostra, obtendo-se o LEM, com um rendimento médio de 6 a $7 \mathrm{~g} / \mathrm{Kg}$ de cultura líquida (Wasser \& Weis, 1999).

O LAP e LAP1 podem ser obtidos a partir de cultura líquida do micélio de L. edodes, ou através de uma variação no método do crescimento do fungo, onde o mesmo pode ser proveniente de um substrato à base de serragem. A extração destes compostos é feita a partir do aquecimento a $60^{\circ} \mathrm{C}$ do extrato micelial (LEM), o qual é solubilizado pela adição de 4 partes de etanol por parte do precipitado, obtendo-se as frações LAP ( $58 \%$ de açúcares e $25 \%$ de proteinas) e LAP1 (65\% de açúcares e $34 \%$ de proteinas). Ambas as frações têm efeito antitumoral quando em mistura (LEM) ou quando separadas nas duas frações (LAP e LAP1) (Togami et al., 1982; Sugano et al., 1982; Breene, 1990).

Atribui-se ao LEM efeitos anti-HIV, de controle da hepatite tipo B, ação antibacteriana e efeito imunomodulatório ou imunopotenciador (estimulando os sistema de defesa do hospedeiro) e controle de outras diversas viroses como herpes, caxumba, etc (Sugano et al., 1985; Suzuki et al., 1986; Mizoguchi et al., 1987; Suzuki et al., 1988; Sarkar et al., 1993; Jones, 1995; Yamamoto et al., 1997).

Suzuki et al. (1989) fracionaram o LEM em solução etanólica onde obtiveram um composto que chamaram de neo PPT1, que após novo fracionamento através de cromatografia hidrofóbica, usando phenyl-sephagarose, foram obtidas as substâncias EP1, EP2, EP3. A fração EP3 apresentou maior atividade anti-HIV in vitro em relação às demais frações, inibindo completamente os efeitos citopatológicos do vírus, em uma concentração de $20 \mu \mathrm{g} / \mathrm{ml}$, pela inibição da transcriptase reversa e apresentando efeito citotóxico à $200 \mu \mathrm{g} / \mathrm{ml}$. 
Por sua vez, Yoshida et al. (1988) obtiveram através de sulfatação das moléculas de lentinan um composto sulfonado ligno-solúvel, como o EP3, porém de estrutura química diferente, onde o mesmo foi efetivo na adsorção de HIV-1 em células CD4 (as quais são inicialmente atacadas pelo vírus).

A fração EP3 também é conhecida como fração lignina solúvel em água, pois a mesma contém aproximadamente $81,1 \%$ de lignina solúvel em água, 3,2\% de proteinas e 12,2\% de carboidratos (Suzuki et al., 1990).

Os mesmos autores, utilizando-se da fração EP3, fizeram a digestão de proteínas (EP3-PR), carboidratos (EP3-KL) e da lignina (EP3-DL), sendo essas amostras testadas novamente para suas atividades imunológicas e anti HIV-1. Os resultados mostraram que somente para a amostra EP3-KL existiu perda completa das atividades imunomodulatórias e anti-HIV-1, sugerindo assim a importância da lignina nesta fração.

Suzuki et al. (1989) também fracionaram a amostra EP3 através de cromatografia de filtração a gel, em coluna de sephacryl S-300, e obtiveram outras 4 frações denominadas EPS1, EPS2, EPS3, e EPS4. Somente a fração EPS4, com menor peso molecular, mostrou um melhor efeito antiviral para HIV-1 e sem efeito citotóxico. Por sua vez, Sorimaki et al. (1990) demonstraram o completo efeito inibitório sobre vírus da herpes tipo 1 e 2 pelo uso da fração EP3, além de efeitos de redução do número de partículas para virus da polio, vírus da caxumba e WEE (vírus da encefalite eqüina).

Chihara et al. (1969) demonstraram que polissacarídeos de alto peso molecular do tipo $\beta$ glucana, provenientes de basidiocarpos, entre eles o lentinan, apresentam efeito imunoativo. Suzuki et al. (1986) e Suzuki et al. (1988) também comprovaram este efeito imunoprotetor para glicoproteínas ou $\beta$ glucana ligadas a proteina, como a fração LEM, que também apresenta alto peso molecular. Deste modo, Suzuki et al. (1990) sugerem que o efeito imunoprotetor ou imunomodulatório é ativado de maneira mais eficiente por moléculas de alto peso, como o lentinan e o próprio LEM. Por sua vez, moléculas de menor peso molecular exibem melhor efeito antiviral, por exemplo o EP3 e, com maior atividade ainda as frações purificadas EPS1,2,3 e 4, sendo a fração EPS4 a de menor peso molecular e melhor atividade antiviral. 
O cogumelo shiitake, após desenvolver-se em meio de cultura líquido, apresenta uma outra fração denominada de JLS-18, a qual é constituída de 65 à $75 \%$ de lignina e 15 à $30 \%$ de polissacarídeos, e 10 à $20 \%$ de proteínas. Através de testes in vitro e in vivo foi demonstrada a eficiência desta fração no controle do vírus da herpes (Hobbs, 1996).

Yamamura \& Cochran (1976) através do uso de extrato aquoso de basidiocarpos secos de L. edodes, obtiveram controle do vírus da influenza em ratos, e denominaram o composto de $\mathrm{Ac} 2 \mathrm{P}$, o qual tratava-se de um polissacarídeo, composto principalmente de pentoses, solúvel em água e que atua diretamente na inibição da replicação viral. O Ac2P parece não interferir diretamente no sistema imunológico, mas diretamente sobre o vírus (Yamamura \& Cochran, 1976).

Suzuki et al. (1974) identificaram um RNA de dupla hélice (ds-RNA), como semelhante a uma partícula viral. O RNA presente provavelmente tenha realmente origem viral, sendo que esse ds-RNA atua como um indutor na produção de interferon, que são proteínas celulares que atuam inibindo a replicação de vírus em células invadidas pelos mesmos (Takehara et al., 1979).

A polifenol oxidase uma enzima protéica e que está envolvida em reações de escurecimento ou bronzeamento do micélio do cogumelo, também apresenta efeitos inibitórios de carcinoma 180 e tumor $\mathrm{MH}-134$, sendo a fração proteica responsável por este efeito.

A eritadenina, também chamada de lentinacin ou lentisina [2(R), 3(R)dihidroxi-4-(9-adenil)-ácido butírico)], foi identificada por Chibata et al. (1969). E obtida a partir de cogumelos secos, seguida de extração etanolica, com aproveitamento de $80 \%$ de eritadenina, a qual tem um efeito hipocolerestêmico (Kaneda e Tokuda, 1966; Sugiyama et al., 1993; 1995; Wasser \& Weis, 1999) e ação antiviral (Cochran, 1978). A eritadenina pode ser encontrada também em pequenas quantidades na fração LEM (Hobbs, 1996). 
Mais recentemente, Yang \&Yang (1995) isolaram e purificaram 2 novos polissacarideos oriundos de micélio de L. edodes, os quais foram classificados como Le2-1 e Le-2-2. Esses compostos apresentam efeito anti-carcinogênico para carcinomas estomacais humanos, sendo diferentes dos demais polissacarídeos já identificados (lentinan e KS-2), visto essas novas frações apresentarem diferenças em relação ao seu peso molecular e à composição de monossacarídeos.

Diversas substâncias de efeito antimicrobiano foram encontradas no cogumelo shiitake. Bianco (1981) relatou que o cogumelo L. edodes. também apresenta atividade antibiótica contra a levedura Candida albicans e contra as bactérias Staphylococcus aureus e Bacillus subtilis. A cortinelina é uma substância anti-bacteriana encontrada no shiitake e com largo espectro, atuando sobre bactérias do tipo gram negativas e positivas. Tsuneda \& Thorn (1994) observaram que algumas linhagens do cogumelo shiitake que deveriam ser susceptíveis a Pseudomonas putida, eram capazes de causar uma violenta bacteriólise das células bacterianas.

Komemushi et al. (1996) purificaram, a partir de cultura líquida de micélio, um composto formado por um álcool $\beta$-fenetil e lentinamicina, sendo esta última a fração de maior efeito antibacteriano. Morita \& Kobayashi (1967) citam a lenthionina como um potente agente bactericida e anti-fúngico também.

Ishikawa (1997) obteve atividade anti-bacteriana a partir de extratos de $L$. edodes para as bactérias: Bacillus, Listeria, Staphylococcus, Acinetobacter, Salmonella, Serratia, Enterobacter, Escherichia, Klebsiella, Proteus, Pseudomonas, Shigella e Yersinia. Além de evidenciar melhor controle de bactérias do tipo gram positivas.

Hirasawa et al. (1999) prepararam 3 diferentes extratos a partir de corpos de frutificação secos de L. edodes: um extrato aquoso, um extrato etanólico e outro extrato com clorofórmio. Os autores observaram um maior efeito antibacteriano para os extratos com solvente orgânico para o controle de bactérias da cavidade bucal. Foi observado também efeito bacteriostático apenas para os extratos aquosos, e bactericida para os extratos obtidos utilizando-se dos solventes orgânicos. Além disso, apenas o extrato aquoso perdia a sua eficiência no controle bacteriano, quando aquecido à temperaturas de $60^{\circ} \mathrm{C}$ durante 1 hora. 
Paccola (1997) utilizando-se de extratos do cogumelo shiitake, observou efeitos de natureza fungistática a C. albicans. Maki (1999) obteve também respostas fungistáticas no controle de $C$. albicans pelo uso de extratos de cogumelo shiitake e sugeriu que o princípio ativo envolvido no controle não é de natureza proteica.

Além dos efeitos citados, o cogumelo shiitake tem muitas outras substâncias biológicamente ativas e para várias outras finalidades, entre as quais pode-se destacar as redutoras de colesterol e diabete, efeito anticoagulante e antitrombótico, efeito radioprotetor, regenação óssea, reneradoras e revitalizantes de pele, ação antiúlcera e efeito anticoagulante (Jong \& Birmingham, 1993).

\subsubsection{Uso potencial no controle de doenças de plantas}

Os trabalhos existentes a respeito do uso do cogumelo "shiitake" na área de controle de doenças de plantas são bastante escassos, em especial para o uso do cogumelo no controle de fitopatógenos fúngicos. Os principais estudos do cogumelo têm sido no controle de TMV em fumo e poucas bactérias fitopatogênicas.

Takagi \& Shimada (1977) e Takagi et al. (1977) relatam que através do uso de extratos aquosos do crescimento micelial do "shiitake" (LEM) era possível obter a redução de sintomas locais e sistêmicos, além de inibir a replicação das partículas virais de TMV em plantas de fumo. Takagi \& Sugimura (1977) encontraram que as preparações dos basidiocarpos do "shiitake" eram efetivas no controle do TMV em fumo, somente quando da aplicação dos extratos antes da inoculação do vírus ou conjuntamente com o mesmo.

Os extratos do corpo de frutificação do shiitake apresentam um poderoso efeito inibidor do CMV (vírus do mosaico da abobrinha) e TMV (Kobayashi et al., 1987). Na mesma linha, os autores Kobayashi et al. (1987) extraíram de basidiocarpos secos, uma substância com atividade inibitória de infecção viral de TMV em plantas de fumo, a qual identificaram como uma proteína simples sem carboidratos e com 199 resíduos de aminoácidos, sendo esta proteína denominada de proteína do corpo de frutificação (FBP - Fruit Body Protein). 
Takazawa et al. (1982) purificaram um componente presente em cogumelo "shiitake" desidratado, conhecido por bis[(metilsulfonil) metil]dissulfido, o qual apresentou uma potente ação antifúngica sobre o fitopatógeno Trichophyton spp. Por sua vez Maki (1999) obteve controle dos fitopatógenos Helminthosporium spp. $H$. euphorbiae, F. solani e Phomopsis sojae pelo uso de extratos do cogumelo e evidenciaram um efeito fungistático e termolábil do composto.

Komemushi et al. (1996) isolaram do cogumelo "shiitake", algumas substâncias com efeito antimicrobiano entre as quais beta-fenetil álcool e octa-2,3-dieno5,7 dieno-1-ol (lentinamycina), e demonstraram que as mesmas são efetivas no controle de bactérias gram negativas. E, tendo, em vista que a maioria das bactérias fitopatogênicas são do tipo gram negativas, temos então um bom indicativo do potencial de uso do L. edodes para o controle de bactérias fitopatogênicas.

Pacumbaba et al. (1999) utilizando-se de lixiviado de crescimento micelial do cogumelo shiitake em substrato a base de serragem, obteve controle in vitro das bactérias fitopatogênicas $P$. syringae pv. glycinea, $P$. syringae pv. tabaci, $X$. campestris pv. campestis, E. amylovora, R. solanacearum, Curtobacter flaccumfaciens pv. flaccumfaciens e de bactérias importântes na área de alimentos e saúde pública como Bacillus cereus, E. coli, Listeria monocytogenes, Salmonella typhimurium e Staphyloccoccus aureus. Os mesmos autores fizeram aplicações do lixiviado em plantas de feijão e tomate, as quais foram inoculadas a seguir com $C$. flaccumfaciens pv. flaccumfaciens e $R$. solanacearum respectivamente. Os resultados evidenciaram também o controle in vivo para as bactérias testadas, onde os autores sugerem que a provável substància antibacteriana presente seja a cortinelina.

\subsection{Perspectiva futura}

A área de Fisiologia do Parasitismo tem contribuído e esclarecido as bases bioquímicas e fisiológicas do processo das interações patógeno hospedeiro, tem fornecido subsidios para que sejam encontrados e desenvolvidos novos métodos para o controle de doenças de plantas. 
Como exemplo, o uso de antipenetrantes e a indução de proteção em plantas, além disso, contribui para a pesquisa em resistência a doenças, principalmente na área de biotecnologia (Pascholati, 1993)

Diversos autores já demonstraram a indução de proteção em plantas em condições controladas (Sequeira, 1983) e raramente em condições de campo (Roveratti, 1989). Piccinin (1995) demonstrou ser possível a indução de proteção, pela aplicação de suspensões de $S$. cereviseae, inclusive em condições de campo para sorgo contra os fitopatógenos E. turcicum e C. sublineolum, e com produções compatíveis aos tratamentos controle com aplicação de fungicidas, além de controle de $X$. campestris pv. passiflora e $B$. cinerea.

A indução de proteção como já foi citada, pode ser tanto local como sistêmica, sendo a proteção sistêmica altamente desejável, devido principalmente facilitar a aplicação do indutor, não sendo necessárias aplicações extremamente uniformes, o que também é um dos problemas do controle químico.

A indução de proteção de plantas constitui-se na medida de controle de doenças, que não apresenta poluição ou toxidez aos humanos plantas ou animais (Ryals et al., 1996). Deve-se levar em consideração que a tendência mundial nos últimos anos, é de que os defensivos agrícolas sejam banidos gradualmente de uso, em função de produtos menos tóxicos ao homem, o que implica no desenvolvimento de novas tecnologias alternativas para o de controle de doenças.

Portanto, a indução de resistência em plantas mostra-se como um dos métodos de controle com grande potencial de uso, devido à possibilidade de se obter proteção a doenças de modo sistêmico e duradouro, além de possibilitar a combinação com outros métodos no controle, para um possível manejo integrado (Sequeira, 1983). Outro ponto importante na indução de proteção é o tipo de indutor empregado, ou seja, vários indutores têm sido estudados desde agentes bióticos como $S$. cereviseae (Roveratti, 1989; Silva \& Pascholati, 1992; Roncatto \& Pascholati, 1993; Piccinin, 1995) e B. thuringiensis (Roveratti et al., 1987) além de indutores abióticos, como ácido acetil salicílico, ácido 2,6 dicloroisonicotínico (Ryals et al., 1996) e goma xantana (Bach, 1997). 
E como o agente indutor de proteção é um importante componente na ativação da proteção de plantas, torna-se necessário conhecer os seus mecanismos de reconhecimento, ação e possíveis novos indutores (Ryals et al., 1996; Pascholati, 1997).

O cogumelo "shiitake" apresenta um bom potencial como elicitor de proteção, em virtude de tratar-se de um fungo, no entanto, ainda são necessários trabalhos de pesquisa que comprovem realmente este potêncial. No entanto esse cogumelo, vem sendo bastante utilizado na área médica para o controle de diversas doenças fúngicas bacterianas e virais, e também diversas substâncias já foram extraídas do shiitake e patenteadas para o uso terapêutico (Jong \& Birmingham, 1993).

Porém, ainda pouco se sabe a respeito de seu possível uso na área agrícola, isto principalmente devido à falta de trabalhos nesta linha de pesquisa. Assim sendo, o uso do "shiitake" no controle de fitopatógenos é um campo ainda a ser explorado e desvendado (Przybylowicz \& Donoghue, 1990; Jong \& Birmingham, 1993). E para reforçar esta possibilidade no uso do "shiitake" para o controle de doenças de plantas, temos o exemplo recente de lançamento da molécula strobirulina. Essa molécula é derivada de um cogumelo comestível presente em florestas, causador de podridão branca, assim como o L. edodes, o qual apresenta controle sobre fungos ascomicetos, basidiomicetos, deuteromicetos e uma pequena ação sobre os oomicetos (Ypema \& Gold, 1999). Depois destes argumentos, resta-nos apenas verificar a viabilidade real do L. edodes no controle de doenças de plantas. 


\section{MATERIAL E MÉTODOS}

Inicialmente, os ensaios de laboratório foram conduzidos visando a seleção dos diferentes extratos obtidos do basidiocarpo L. edodes (shiitake), com algum efeito sobre o crescimento micelial, esporulação e ou formação de apressórios para fungos, bem como sobre a multiplicação de bactérias. Além disso, foram efetuados testes visando a elicitação de fitoalexinas em sorgo e em soja, e dosagens de açúcares e proteinas das diferentes amostras. Com base nestas informações, foram selecionadas as melhores preparações para serem utilizadas nos testes com plantas inoculadas com os patógenos em casa de vegetação.

\subsection{Crescimento dos patógenos fúngicos, bacterianos e do shiitake}

\subsubsection{Exserohilum turcicum}

O E. turcicum foi isolado de folha de sorgo contendo lesões características da doença. Foram coletados pedaços da folha de sorgo cv. Brandes com sintomas típicos da doença e cortados em pedaços de aproximadamente $7 \mathrm{~mm}^{2}$ na região de transição entre tecido sadio e infectado, sendo em seguida lavados em água corrente e mergulhados em solução de água destilada mais hipoclorito de sódio comercial na proporção de $2: 1(\mathrm{v} / \mathrm{v})$ durante 5 minutos. 
A seguir, os pedaços foliares eram lavados em água destilada e plaqueados em placas de Petri, contendo 3 folhas de papel de filtro previamente umidecidas. As placas foram incubadas em estufa à $27^{\circ} \mathrm{C}$, sob condição de escuro durante 30 dias, quando então procedeu-se a retirada dos conídios com o auxílio de uma agulha, observados através de um microscópio estereoscópico, os quais foram colocados em meio BDA (batata dextrose ágar). Decorridos alguns dias, foram feitos novos isolamentos a partir de pontos com crescimento micelial de E. turcicum para a seleção de culturas puras do patógeno.

As colônias isoladas foram mantidas em crescimento por 30 dias, tempo em que as mesmas já haviam tomado toda a placa e iniciado o processo de esporulação.

\subsubsection{Colletotrichum sublineolum}

Para a obtenção de C. sublineolum, procedeu-se da mesma maneira que para o isolamento de E. turcicum, onde utilizou-se de folhas de sorgo cv. Tx 398-B com sintomas característicos da doença. Os conídios obtidos foram transferidos para placas contendo meio de aveia, as quais foram incubadas sob luz U.V. (comprimento de onda longo), à temperatura de $21^{\circ} \mathrm{C}$. Após um período de 20 dias, procedeu-se nova repicagem para meio de aveia. As colônias fúngicas obtidas foram incubadas durante um período de 20 dias antes de seu uso.

\subsubsection{Xanthomonas campestris pv. passiflora}

Foram selecionadas folhas de maracujazeiro da variedade azedo amarelo com sintomas sistêmicos característicos da bacteriose. Essas folhas foram lavadas em água corrente e secas em papel toalha, sendo as mesmas cortadas em pequenos pedaços (aproximadamente $5 \mathrm{~mm}^{2}$ ) na região de transição entre tecidos sadios e infecção sistêmica e os pedaços colocados sobre as làminas de vidro previamente limpas com acetona e álcool. 
Os pedaços de folha sobre as lâminas receberam uma gota de água destilada, sendo em seguida colocados sob microscópio óptico para a observação de corrida bacteriana. Quando ocorria a presença da mesma, procedia-se a maceração dos tecidos de maracujá presentes na lâmina. Após a maceração, a lâmina foi inclinada levemente para o escorrimento da gota para uma de suas extremidades e remoção dos resíduos grosseiros de folha presentes no macerado. Com o auxílio de uma alça de platina, o macerado de folha mais suspensão bacterinana foi plaqueado em forma de estrias sobre meio de cultura NA (Nutriente Ágar) a partir do macerado obtido, sendo as placas incubadas à $27^{\circ} \mathrm{C}$ e condição de escuro. Após 3 dias, procedeu-se a purificação das colônias bacterianas, tomando-se colônias isoladas com coloração amarelada e formato arredondo típico da bactéria. Estas colônias foram repicadas para novo meio NA e utilizadas com no máximo 3 dias de crescimento, após a repicagem.

\subsubsection{Lentinula edodes}

$\mathrm{O}$ isolado do cogumelo L. edodes (shiitake) empregado nos ensaios era proveniente de basidiocarpos, com 5 anos de seleção e cultivo em toras de Eucaliptus grandis, no Setor de Fitopatologia da ESALQ/USP. Em condições de laboratório o isolado de $L$ edodes foi cultivado em meio $\mathrm{BDA}$, sob condição de escuro e temperatura média de $22^{\circ} \mathrm{C}$. As repicagens foram feitas mediante a retirada de discos contendo crescimento micelial das colônias, com $0,5 \mathrm{~cm}$ de diâmetro e 14 dias de idade.

$\mathrm{O}$ isolado de shiitake empregado nos ensaios, denominado de isolado "Piracicaba", encontra-se depositado na micoteca do Instituto de Botânica de São Paulo com o número de registro CCB 654. Este isolado apresenta como características básicas, um bom desenvolvimento micelial entre 20 e $25^{\circ} \mathrm{C}$, crescimento em meio mínimo de Lilly, boa competitividade in vitro a contaminantes como: Aspergillus sp., Penicillium sp. e inclusive Trichoderma sp. 
Além de apresentar bom desenvolvimento in vitro e em toras de eucalipto, assim como boa produção de basidiocarpos (Pascholati et al., 1996;1997). Portanto, devido a estas características optou-se pelo uso deste único isolado nos ensaios.

$\mathrm{O}$ isolamento do fungo, preparo de inóculo, inoculação e colheita foram feitos conforme metodologias descritas por Pzybylowicz (1990). O cultivo do shiitake foi realizado em toras de E. grandis (Figura 1), sendo que após 8 meses da inoculação foram iniciadas as primeiras colheitas dos basidiocarpos, os quais eram armazenados em congelador à $-20^{\circ} \mathrm{C}$ ou então secos ao sol até peso constante.

\subsection{Meio de cultura para os ensaios in vitro}

O meio de BDA (batata dextrose ágar) foi utilizado como meio de cultura padrão para a realização de todos os experimentos in vitro, com as diferentes preparações dos basidiocarpos de L. edodes. A escolha deve-se ao fato deste meio proporcionar um bom crescimento à todos os patógenos testados, além do próprio shiitake, e não interferir na esporulação dos fungos patogênicos testados.

3.3. Metodologias de repicagem e avaliação dos ensaios in vitro com os patógenos $E$. turcicum, $C$. sublineolum X $X$. campestris pv. passiflora

São descritas as metodologias de repicagem dos patógenos e avaliação dos ensaios realizados in vitro com os preparados do cogumelo L. edodes. 


\subsubsection{Repicagem e avaliação dos patógenos $E$. turcicum e $C$. sublineolum}

As repicagens dos patógenos E. turcicum e C. sublineolum foram feitas tomando-se discos de $0,5 \mathrm{~cm}$ de diàmetro, contendo crescimento micelial mais esporos, os quais foram colocados no centro das placas de Petri, e incubados nas mesmas condições descritas nos itens 3.1.1. e 3.1.2., sendo avaliados os parâmetros de crescimento micelial e esporulação, após a tomada por completo das placas pelos referidos patógenos. As medidas de crescimento micelial foram feitas diretamente pela avaliação do diâmetro das colônias, as quais eram realizadas assim que o fungo presente em um dos tratamentos atingisse o diâmetro máximo da placa de Petri. Para a avaliação da esporulação, foram adicionados $10 \mathrm{ml}$ de água destilada por placa de Petri e com auxílio de uma alça de Drigalski procedeu-se a raspagem do meio e filtragem através de gaze e avaliação do número de esporos na suspensão, com auxílio de uma câmara de Neubauer (hematocitometro).

\subsubsection{Repicagem e avaliação de $X$. campestris pv. passiflora}

Para as repicagens em meio de cultura sólido ou líquido ou simplesmente em água, foram tomadas suspensões bacterianas provenientes de culturas com no máximo 3 dias conforme descrito no item 3.1.3., e calibradas as suspensões para $76 \%$ de trânsmitância à $640 \mathrm{~nm}$, sendo essa concentração bacteriana utilizada como padrão para todos os ensaios in vitro.

As avaliações foram efetuadas adicionado-se $10 \mathrm{ml}$ de água destilada por placa de Petri com meio sólido e com auxilio de uma alça de Drigalski, procedia-se o preparo das suspensões bacterianas cujas concentrações foram avaliadas em espectrofotômetro à $640 \mathrm{~nm}$.

Para os ensaios em meio líquido batata dextrose (BD) ou água, realizados em tubos de ensaio, procedeu-se a agitação dos mesmos antes da tomada das aliquotas de $1,5 \mathrm{ml}$ da suspensão bacteriana utilizadas nas medições em espectrofotômetro à 640 nm. 


\subsection{Obtenção das diferentes preparações de $L$. edodes}

Foram obtidas diferentes preparações a partir do basidiocarpo e de crescimento micelial em meio líquido do $L$. edodes, cujas metodologias são descritas a seguir.

\subsubsection{Preparo dos filtrados de basidiocarpo, píleo e estípe}

Para a obtenção dos filtrados de basidiocarpo congelado, procedeu-se o congelamento à $-20^{\circ} \mathrm{C}$ de cogumelos frescos bem como das partes píleo e estípe. $\mathrm{O}$ filtrado de basidiocarpo seco foi obtido pela secagem de cogumelos frescos ao sol, até peso constante. Após a secagem, foi efetuada a divisão do cogumelo nas frações basidiocarpo (píleo mais estípe), píleo e estípe, seguida da moagem de cada uma das frações através de um moinho manual para grãos de café.

Antes do preparo dos filtrados de basidiocarpo seco, as amostras de cogumelo secas e moídas foram hidratadas previamente durante um período de 2 horas à temperatura ambiente, onde para cada 1 grama de amostra foram adicionados $9 \mathrm{ml}$ de água destilada.

O preparo dos filtrados de basidiocarpo secos consistiram no uso de 2 gramas de basidiocarpo píleo ou estípe préviamente hidratados conforme descrito no parágrafo anterior, mais $1 \mathrm{ml}$ de água destilada e deixados em repouso na geladeira por 2 horas à $4^{\circ} \mathrm{C}$, até o momento da filtragem.

Para as amostras de basidiocarpo congelado, procedeu-se a fragmentação das frações basidiocarpo, pileo e estípe individualmente, e adição de $1 \mathrm{ml}$ de água destilada a cada 2 gramas de amostras, sendo em seguida fragmentadas em um triturador Sorvall omni-mixer, até as mesmas apresentarem-se totalmente desintegradas. Terminada esta operação as preparações eram deixadas em repouso por 2 horas à temperatura de $4^{\circ} \mathrm{C}$ em geladeira. 
Em seguida, as amostras de cogumelos seco e congelados eram filtradas à vácuo de filtro de papel comum em um kitassato. Após a filtragem, as amostras eram centrifugadas em centrifuga Sorvall (Du Pont) modelo RC5C, à temperatura de $4^{\circ} \mathrm{C}$, durante $20 \mathrm{~min}$. à $20.000 \mathrm{~g}(12.730 \mathrm{rpm})$.

Terminada a operação, os sobrenadantes foram coletados e filtrados em filtro Whatmann GF/A, do mesmo modo descrito acima. Em seguida, as amostras eram pré-filtradas em sistema Millipore com filtro de $0,2 \mu \mathrm{m}$. Após estas filtragens prévias, as amostras eram levadas para a câmara de fluxo lâminar para a filtragem de esterilização, onde as mesmas eram filtradas através de filtro para seringa esterilizado (Schleicher \& Schuell modelo FP 030/AS) de 0,2 $\mu \mathrm{m}$. Os filtrados esterilizados eram armazenados em geladeira à $4^{\circ} \mathrm{C}$ até o momento de uso.

\subsubsection{Preparo do filtrado autoclavado de basidiocarpo, filtrado de basidiocarpo autoclavado e filtrado congelado de preparações de basidicarpo}

O filtrado autoclavado de basidiocarpo consistia do filtrado de basidiocarpo, autoclavado durante $20 \mathrm{~min}$. à $121^{\circ} \mathrm{C}$ e 1 atm de pressão. Para a obtenção do filtrado de basidiocarpo autoclavado, utilizou-se de basidiocarpos secos e moídos, os quais foram previamente hidratados. Após a hidratação, procedeu-se a adição de água nas proprorção de 2 partes de basidiocarpo moído e hidratado para uma parte de água. Em seguida o material foi submetido à autoclavagem durante $20 \mathrm{~min}$. à $121^{\circ} \mathrm{C}$ e 1 atm de pressão, e filtrado como descrito no item 3.4.1. Os filtrados de basidicarpo, filtrado autoclavado de basidiocarpo e filtrado de basidiocarpo autoclavado foram congelados à $20^{\circ} \mathrm{C}$ durante 12 horas. Em seguida os mesmos foram armazenados à $4^{\circ} \mathrm{C}$, sendo as diferentes preparações de filtrados de basidiocarpo após o breve congelamento, classificados como filtrados congelados das respectivas amostras. 


\subsubsection{Filtrado de crescimento micelial e filtrado de micélio macerado}

Foram preparados 6 erlenmeyers de $500 \mathrm{ml}$ contendo $300 \mathrm{ml}$ de meio BD (batata dextrose), os quais foram repicados com 12 discos de $0,5 \mathrm{~cm}$ de diâmetro de crescimento micelial do cogumelo L. edodes.

Após 160 dias da inoculação, procedeu-se a filtragem dos meios contendo ou não o crescimento micelial de L. edodes, os quais foram filtrados e esterilizados conforme descrito no item 3.4.1. Os filtrados foram classificados como filtrado de crescimento micelial e filtrado de batata dextrose sendo armazenados em geladeira à $4^{\circ} \mathrm{C}$ até o momento de uso.

Por sua vez, o micélio retido no filtro de papel durante a filtragem foi lavado sucessivas vezes com água destilada e colocado para secar ao sol até atingir peso constante. Após a secagem, o micélio obtido foi triturado em almofariz, obtendo-se o micélio seco em pó, do qual obteve-se um filtrado conforme descrito no item 3.4.1. O filtrado de cogumelo seco, assim obtido, foi classificado como filtrado de micélio macerado.

\subsubsection{Lentinan}

A amostra da $\beta$-glucana purificada do cogumelo $L$. edodes, conhecida por lentinan, foi obtida através de importação deste material do Japão, através de doação das amostras por seu fabricante a Companhia Ajinomoto do Japão. As amostras foram diluídas em água na proporção de 20.000 ppm para todos os ensaios in vitro e in vivo. 


\subsection{Métodos de incorporação das preparações de $L$. edodes in vitro}

\subsubsection{Em placas de Petri}

Os diferentes filtrados do cogumelo foram incorporados aos meios de cultura $\mathrm{BDA}$ fundentes, à $\pm 45^{\circ} \mathrm{C}$, em concentrações de $100,1.000,10.000,20.000$ e ou $40.000 \mathrm{ppm}$. Essas concentrações variaram de acordo com o experimento realizado, sendo que para cada uma das concentrações foram feitas 6 repetições. Após a incorporação dos filtrados ao meio de cultura, os mesmo foram mantidos 3 dias em descanso.

Os diferentes filtrados de $L$. edodes foram também distribuídos sobre o meio de cultura BDA nas dosagens de $100,1.000,10.000$ e 20.000 ppm, variando conforme o experimento realizado. Onde as placas foram armazenadas durante 7 dias antes do uso.

\subsubsection{Em tubos de ensaio}

Foram preparados tubos de ensaio contendo água destilada no volume de $7 \mathrm{ml}$ por tubo. Após a autoclavagem dos tubos, procedeu-se a adição dos diferentes filtrados de $L$. edodes na concentração final de $20.000 \mathrm{ppm}$ por tubo, além de um tratamento controle contendo água e outro contendo meio líquido $\mathrm{BD}$, no total de 6 repetições para cada tratamento.

Após a adição dos filtrados do shiitake nos tubos, adicionou-se $1 \mathrm{ml}$ de suspensão bacteriana à $76 \%$ de transmitância à $640 \mathrm{~nm}$. Em seguida, o volume nos tubos foi ajustado para $10 \mathrm{ml}$ adicionando-se água destilada esterilizada e agitação dos mesmos. Terminado o preparo dos tubos, os mesmos foram incubados no escuro durante 24 horas a $30^{\circ} \mathrm{C}$. Após a incubação, foram tomadas alíquotas de $250 \mu \mathrm{l}$ de cada um dos tubos, as quais foram plaqueadas sobre meio BDA e espalhadas imediatamente, com o auxilio de uma alça de Drigalski. 
As placas assim preparadas foram incubadas em condição de escuro a $30^{\circ} \mathrm{C}$, sendo que decorridos 3 dias, procedeu-se a avaliação dos resultados conforme descrito no item 3.3.2. Para as placas onde aparentemente não havia crescimento bacteriano, procedeu-se a um segundo plaqueamento das suspensões em novo meio BDA, utilizando-se de uma alça de platina. As avaliações do crescimento bacteriano nas placas foram feitas do $3^{\circ}$ ao $7^{\circ}$ dia após a repicagem, quanto à presença ou ausência de colônias bacterianas.

\subsection{Preparo de lâminas recobertas com poliestireno}

As lâminas de vidro para microscopia foram lavadas com água e detergente, sendo secas com papel toalha e desengorduradas com álcool $98 \%$. O preparo da solução de poliestireno constituiu na fragmentação de 1 placa de Petri de poliestireno ( $9 \mathrm{~cm}$ de diâmetro), a qual foi colocada em frasco de vidro com tampa esmerilhada. Em seguida, adicionou-se $100 \mathrm{ml}$ de acetato de amila e o frasco foi deixado em repouso por 24 horas. Decorrido este período, procedeu-se a homogeneização do material com um bastão de vidro. Em seguida, as lâminas foram mergulhadas na solução de acetato de amila e poliestireno, com o auxilio de uma pinça, e rapidamente retiradas. As lâminas foram colocadas para secar inclinadas em uma bandeja forrada com papel toalha no mínimo por 48 horas antes do uso. Todo o processo de preparo das lâminas foi realizado no interior de uma capela.

\subsection{Avaliação da germinação e formação de apressórios in vitro na presença de preparações de $L$. edodes}

Foram utilizadas 2 lâminas recobertas de poliestireno por tratamento, onde em cada uma das lâminas foram depositadas 3 gotas com $80 \mu l$ de suspensão de conidios, $\left(10^{2}\right.$ conídios $\left./ \mathrm{ml}\right)$ de E. turcicum ou C. sublineolum. 
As suspensões de conídios foram preparadas com os diferentes filtrados de L. edodes, à uma concentração de 20.000 ou 50.000 ppm para E. turcicum e 20.000 ppm para C. sublineolum. As lâminas contendo E. turcicum foram incubadas à $27^{\circ} \mathrm{C}$ no escuro, enquanto que o C. sublineolum foi incubado à $21^{\circ} \mathrm{C}$ e luz negra constante (comprimento de onda longo), sendo ambos os fungos incubados por um período de 24 horas e as lâminas mantidas em câmara úmida para se evitar a secagem das gotas. Após este período, procedeu-se a contagem do número de conídios germinados e apressórios formados, em um total de 6 gotas para cada um dos tratamentos e 100 esporos por gota.

\subsection{Determinação de carboidratos (açúcar solúveis) nas diferentes preparações de L. edodes pelo método de Lever}

O conteúdo de açúcares redutores foi determinado pelo método de Lever (1972), utilizando-se de $0,5 \mathrm{ml}$ das diferentes preparações, mais $1,5 \mathrm{ml}$ de hidrazida do ácido $p$-hidroxibenzóico $0,5 \mathrm{M}$, sendo os resultados obtidos expressos em $\mu \mathrm{g}$ de glicose/ml com base em curva padrão (Figura 2), em um total de 5 tubos por tratamento. Logo após a colocação do reagente, os tubos foram agitados durante alguns segundos, sendo em seguida colocados em banho maria à $100^{\circ} \mathrm{C}$ durante $5 \mathrm{~min}$. Após esta etapa, as amostras foram resfriadas em água mais gelo e a absorbância determinada à $410 \mathrm{~nm}$.

\subsection{Determinação de proteínas nas diferentes preparações de $L$. edodes}

Foi empregado o método de Bradford (1976) para a determinação do conteúdo de proteínas totais. Foram adicionados $0,2 \mathrm{ml}$ do reagente de Bradford concentrado a cada $0,8 \mathrm{ml}$ de preparado do fungo. Após $5 \mathrm{~min}$, foi realizada a leitura da absorbância à $595 \mathrm{~nm}$. A concentração de proteínas de cada amostra foi expressa em termos de equivalentes $\mu \mathrm{g}$ de albumina de soro bovino (ASB) em $0,8 \mathrm{ml}$ de amostra ( $\mu \mathrm{g}$ de proteína $/ 0,8 \mathrm{ml}$ ), calculada com base em curva padrão de ASB variando de 0 a 25 $\mu \mathrm{g} / 0,8 \mathrm{ml}$ (Figura 3 ). 


\subsection{Determinação de $\beta$-glucana nas diferentes preparações de $L$. edodes}

As dosagens de $\beta$-glucana foram realizadas no Setor de Bioquímica Fitopatológica do Instituto Biológico de São Paulo sob a supervisão da $\mathrm{Dr}^{\mathfrak{a}}$. Erna Bach.

\subsection{Efeito das preparações de $L$. edodes no acúmulo de fitoalexinas em mesocótilos estiolados de sorgo}

As sementes de Sorghum bicolor (cv. Brandes) foram embebidas em água durante 4 horas à temperatura ambiente, sendo a seguir dispostas entre camadas de papel de filtro previamente umidecidas. Após 5 dias de permanência no escuro, as plântulas foram expostas a luz por 2 horas para a paralisação da elongação dos mesocótilos.

Os mesocótilos com a coleoptile foram cortados $0,5 \mathrm{~cm}$ acima da base e colocados em tubos de ensaio contendo $3,0 \mathrm{ml}$ das preparações de $L$. edodes, água destilada esterilizada, batata dextrose ou suspensão de conídios de C. sublineolum ( $2 \times 10^{5}$ conídios $/ \mathrm{ml}$; controle positivo).

Os tubos contendo os mesocótilos foram vedados com plástico Magipack e mantidos à $25^{\circ} \mathrm{C}$ sob luz fluorescente, durante 60 horas. Cada repetição era representada por 5 mesocótilos, sendo realizadas 5 repetições por tratamento.

Para as dosagens de fitoalexinas, procedeu-se a retirada dos mesocótilos dos tubos de ensaio e a secagem dos mesmos, sendo a parte basal $(0,5 \mathrm{~cm})$ de cada mesocótilo cortada e descartada. A partir da base eliminada efetuou-se novo corte à 2,5 $\mathrm{cm}$. Esse segmento remanescente de $2,5 \mathrm{~cm}$ foi cortado em 3 partes proporcionais e colocado em tubos de ensaio contendo metanol $80 \%$ acidificado com $0,1 \%$ de $\mathrm{HCl}(\mathrm{v} / \mathrm{v})$ (Nicholson et al., 1988). Os tubos assim preparados foram mantidos em geladeira à $4^{\circ} \mathrm{C}$, para permitir a completa extração dos pigmentos. 
Após 96 horas, o metanol foi coletado com pipeta Pasteur e o acúmulo de fitoalexinas nos mesocótilos de sorgo, em resposta ao tratamento com as diferentes preparações de L. edodes, foi avaliado com base na determinação da absorbància à 480 $\mathrm{nm}$, sendo os resultados expressos em $\mathrm{A}_{480 \mathrm{~nm}} /$ grama de tecido fresco (Lopez \& Pascholati, 1992; Nicholson et al., 1988).

\subsection{Efeito das preparações de $L$. edodes no acúmulo de gliceolina em cotilédones de soja}

Sementes de Glycine max (soja) da variedade IAC 8 foram plantadas em caixas contendo areia esterilizada. Após 17 dias em condição de casa de vegetação, procedeu-se a coleta dos cotilédones das plântulas emergidas. Os cotilédones foram lavados com água destilada e enxugados com papel toalha, sendo descartados aqueles que apresentavam algum tipo de dano.

Nos cotilédones selecionados, efetuou-se um corte de $1 \mathrm{~mm}$ de espessura e $6 \mathrm{~mm}$ de diàmetro na superfície inferior dos mesmos. Cada repetição foi constituída de 10 cotilédones dispostos sobre 3 discos de papel de filtro, previamente umidecidos com água destilada esterilizada, e dispostos em placas de Petri.

Foram aplicadas alíquotas de $75 \mu \mathrm{l}$ das diferentes preparações de $L$. edodes, água, batata dextrose ou suspensão de células de $S$. cereviseae $(25 \mathrm{mg}$ de fermento Fleishchmann/ml de água destilada, controle positivo) sobre cada um dos cotilédones, em um total de 5 placas por tratamento.

As placas foram incubadas por 20 horas à $26^{\circ} \mathrm{C}$ no escuro. Após esse periodo, os cotilédones de cada uma das placas foram transferidos para erlenmeyers contendo $20 \mathrm{ml}$ de água destilada esterilizada e deixados em agitação por 1 hora para a extração das fitoalexinas. A suspensão aquosa contendo os cotilédones foi filtrada através de papel de filtro comum, e a absorbância do filtrado determinada à $285 \mathrm{~nm}$ (Ayers et al., 1976) 


\subsection{Efeito das preparações de $L$. edodes nas interações planta-patógeno}

Nos ensaios visando a proteção das plantas, foram somente utilizados os melhores preparados de $L$ edodes, selecionados com base nos teste realizados in vitro.

\subsubsection{Interações sorgo $\mathrm{x}$ E. turcicum e $C$. sublineolum}

Foram preparados vasos contendo sementes de sorgo cv. Brandes (susceptivel a $E$. turcicum) e vasos com sorgo cv. Tx-398-B (susceptivel a $C$. sublineolum). Para cada um dos cultivares foram plantadas 6 sementes por vaso, com capacidade para $2,5 \mathrm{~kg}$ de latossolo vermelho amarelo, sendo que após 15 dias da germinação procedeu-se o desbaste, deixando-se apenas 3 plantas por vaso.

\subsubsection{Aplicação das preparações de $L$. edodes e inoculação dos fungos}

Para cada patógeno foram preparados 4 tratamentos, representados por: água (controle), patógeno (controle), lentinan e filtrado de basidiocarpo, sendo cada tratamento composto de 5 repetições. Nos ensaios foram utilizadas plantas com 50 dias de idade, a fase fenológica 14, que corresponde a quarta folha aberta e visível (Frederiksen, 1991). Para as adubações das plantas, empregou-se 2 gramas de sulfato de amônio por vaso, a cada 15 dias.

As plantas de sorgo foram previamente tratadas com as preparações elicitoras: lentinan e filtrado de basidiocarpo, com o auxilio de um aspersor manual Brudden de capacidade para 0,5 L. A aspersão dos elicitores foi efetuada na concentração de $20.000 \mathrm{ppm}$, em ambas as faces da folha, e em todas as folhas das plantas dos referidos tratamentos. Foi utilizado um volume médio de $5,5 \mathrm{ml}$ das preparações por planta, as quais foram aplicadas 48 horas antes da inoculação com os patógenos. 
Decorrido este período da aplicação dos elicitores, procedeu-se a inoculação das plantas. A suspensão de esporos $\left(5 \times 10^{5}\right.$ conídios $\left./ \mathrm{ml}\right)$ de E turcicum foi aspergida em sorgo Brandes, sobre todas as folhas e plantas do ensaio (exceto controle água), e incubadas em câmara úmida por 24 horas e condição de escuro. Após este período, a câmara úmida foi removida e as plantas mantidas em sala de crescimento à $25^{\circ} \mathrm{C}$ e fotoperíodo de 16 horas.

No caso de C. sublineolum, suspensões de esporos a concentração de $\left(2,5 \times 10^{4}\right.$ conidios $\left./ \mathrm{ml}\right)$ foram inoculadas da mesma forma que para o E. turcicum e as plantas mantidas em câmara úmida por 24 horas em condição de luz constante. Após este período, as plantas foram removidas da câmara úmida e levadas para casa de vegetação à $25^{\circ} \mathrm{C}$.

\subsubsection{Avaliação dos ensaios com E. turcicum e $C$. sublineolum}

A avaliação dos ensaios foi realizada tomando-se a $5^{\text {a }}$ folha de cada uma das plantas. Para o E. turcicum, a avaliação foi efetuada 45 dias após a inoculação e para o C. sublineolum a avaliação foi realizada 30 dias após a inoculação das plantas. As avaliações dos ensaios foram feitas com base nos parâmetros de severidade da doença nas folhas, sendo que para o E. turcicum foi construída uma escala diagramática para essa finalidade (Figura 4) e para o C. sublineolum utilizou-se de escala já existente (Piccinin, 1995).

\subsubsection{Interação maracujá x $X$. campestris pv. passiflora}

Foram plantadas sementes de Passiflora edulis (maracujá amarelo azedo) em bandejas plásticas contendo substrato plantmax (Eucatex). Após as mudas atingirem um tamanho mínimo de $7 \mathrm{~cm}$, as mesmas foram transferidas para vasos com a capacidade para $2,5 \mathrm{~kg}$. As plantas foram adubadas à cada 15 dias com $2 \mathrm{~g}$ de sulfato de amônio por vaso. 
Após 60 dias do transplante, realizou-se a poda do ápice, removendo-se as folhas novas e as 5 primeiras folhas (cotiledonares e basais), restando no total 7 folhas. As plantas que apresentassem folhas danificadas eram descartadas.

\subsubsection{Aplicação das preparações de $L$. edodes e inoculação da bactéria}

Realizada a poda, procedeu-se a aplicação de $8 \mathrm{ml}$ das preparações elicitoras (na concentração de 20.000 ppm) por planta, representada por: filtrado de crescimento micelial, lentinan e filtrado de estípe, além do controle água. As preparações foram aplicadas nas plantas 48 horas antes das inoculações com as suspensões bacterianas, sendo utilizados 5 vasos por tratamento.

Para as inoculações, utilizou-se de colônias bacterianas com no máximo 3 dias de crescimento em meio NA. Preparou-se uma suspensão bacteriana "mãe", a qual teve a concentração ajustada para $35 \%$ de transmitância à $640 \mathrm{~nm}$ (aproximadamente $10^{7}$ células bacterianas $/ \mathrm{ml}$, medidas pela escala de Mc-Farland) (Piccinin, 1995). A suspensão bacteriana foi aplicada na parte abaxial das folhas, com auxílio de um frasco tipo spray de $200 \mathrm{ml}$, aspergindo-se a mesma a uma distância aproximadamente de $15 \mathrm{~cm}$ da superfície a fim de se obter gotículas pequenas recobrindo toda a extensão das folhas. Após as inoculações, as plantas foram incubadas em câmara úmida durante 3 dias à $35^{\circ} \mathrm{C}$. Decorrido este período, as plantas foram retiradas da câmara úmida e mantidas em casa de vegetação à mesma temperatura (Piccinin, 1995).

\subsubsection{Avaliação dos ensaios com $X$. campestris pv. passiflora}

Após 35 dias das inoculações, foram realizadas as avaliações pela observação de cada uma das folhas respeitando-se as posições relativas das mesmas na planta. Avaliou-se a incidência de infecções locais e sistèmicas (Piccinin, 1995). 


\subsubsection{Interação fumo $x$ vírus do mosaico do fumo (TMV)}

Foram plantadas sementes de fumo (Nicotiana tabacum) $\mathrm{cv}$. TNN e cv. Turkish em bandejas de isopor contendo substrato plantmax (Eucatex). Quando as plantas apresentavam 60 dias de idade, as mesmas foram transferidas para vasos com capacidade para $2,5 \mathrm{~kg}$, sendo mantida apenas 1 planta por vaso. As plantas foram adubadas com $2 \mathrm{~g}$ de sulfato de amònio por vaso a cada 15 dias.

\subsubsection{Aplicação das preparações de $L$. edodes e inoculação do vírus}

Quando as plantas apresentavam 5 folhas distendidas, foram feitas as aplicações dos elicitores em todas as folhas de fumo e em ambos os lados das mesmas, a um volume de $5,5 \mathrm{ml}$ do elicitor por folha. As preparações empregadas foram representadas por: filtrado de basidiocarpo e lentinan, na concentração de 20.000 ppm, além de água (controle).

Após 48 horas da aplicação das preparações, as folhas foram inoculadas com o vírus. Para isso, folhas de fumo Turkish contendo o vírus TMV, as quais apresentavam sintomas típicos da doença, foram maceradas em almofariz ( 1 grama de folha e $2 \mathrm{ml}$ de tampão fosfato $\mathrm{pH} 7,0$ e $0,02 \mathrm{M}$ ). Após este procedimento, foi feita a diluição da amostra inicial em tampão fosfato na proporção de 1: 5.000 .

O macerado de folhas diluído, contendo o vírus, foi aplicado na $5^{\mathrm{a}}$ e $6^{\mathrm{a}}$ folhas de todas as plantas dos cultivares TNN e Turkish, onde após o polvilhamento de carborundum sobre as folhas, procedeu-se umidecimento do dedo indicador no macerado de folhas contendo TMV e em seguida efetuou-se a passagem do mesmo por toda a extensão da folha de uma única vez. Após a inoculação, as plantas foram mantidas em casa de vegetação, bem espaçadas uma das outras. 


\subsubsection{Avaliação dos ensaios com TMV}

Para o fumo TNN procedeu-se a avaliação da incidência de lesões locais na $5^{\mathrm{a}}$ e $6^{\mathrm{a}}$ folhas de cada planta, pela contagem do número de lesões locais em cada uma das folhas avaliadas. Neste caso, efetuou-se uma única avaliação, 30 dias após a inoculação das plantas com o vírus

Para o fumo cv. Turkish, foram realizadas avaliações aos 15 e 30 dias após as inoculações, mediante a coleta de duas amostras de cada planta, representadas por folhas com sintomas do vírus e próximas ao ponteiro. Estas amostras foram identificadas e armazenadas em congelador à $-20^{\circ} \mathrm{C}$, até o momento do uso para a quantificação das partículas virais.

A quantificação das partículas virais presentes nas folhas foi feita através do teste de PTA-ELISA, descrito por (Mowat \& Dawson, 1987). O teste consistiu na maceração das amostras individualmente em almofariz, na presença de tampão carbonato $\left(0,015 \mathrm{M} \mathrm{Na}_{2} \mathrm{CO}_{3}\right.$ e $\left.0,035 \mathrm{M} \mathrm{NaHCO}_{3}, \mathrm{pH} 9,6\right)$ diluído em tampão fosfato na proporção de 1:20. Em seguida, foram colocados $100 \mu$ de cada amostra por "pocinho" de uma placa de poliestireno (marca Corning), onde para cada amostra foram preenchidos 2 "pocinhos", correspondendo à duas aferições por amostra, as quais eram compostas de 10 amostras por tratamento.

As placas foram incubadas por um período de 1,5 horas à $37^{\circ} \mathrm{C}$. Em seguida as placas foram lavadas 3 vezes consecutivamente com PBS Tween $(0,0015 \mathrm{M}$ $\mathrm{KH}_{2} \mathrm{PO}_{4}, 0,14 \mathrm{M} \mathrm{NaCl}, 0,004 \mathrm{M} \mathrm{NaHPO}_{4}$ e 0,003 $\mathrm{M} \mathrm{KCl}$ ). Após a lavagem, as placas foram batidas contra uma porção de toalhas de papel, a fim de se eliminar gotículas remanescente do PBS Tween. Nas placas secas, foram então colocados em cada "pocinho" $100 \mu \mathrm{l}$ de antissoro IgG de coelho ("goat anti rabbit") conjugado com fosfatase alcalina (Sigma A-8025), diluido na proporção de 1:20 em tampão Tris- $\mathrm{HCl}$, $\mathrm{pH} 7,2$. Após a adição do conjugado, as placas foram incubadas por 1,5 hora à $37^{\circ} \mathrm{C}$, sendo que decorrido este período, procedeu-se novamente a lavagem com PBS Tween e secagem das placas. 
Finalmente adicionou-se $100 \mu \mathrm{l}$ de $p$-fosfato de nitrofenil (Sigma $\mathrm{N}$ 9389) diluído em tampão fosfato à $10 \%(\mathrm{pH} 9,8)$ na proporção de $1 \mathrm{mg} / \mathrm{ml}$. As placas foram incubadas no escuro durante 2 horas. Após este período, foram efetuadas as leituras de absorbância do material contido em cada um dos "pocinhos", (leitor de Elisa Metertech $\Sigma 960)$, à $405 \mathrm{~nm}$.

\subsection{Análise estatística}

Para todos os ensaios empregou-se a análise de variância seguida de teste de Tukey a de $1 \%$ de significância sendo os dados analisados com o uso do programa Sanest. 


\section{RESULTADOS E DISCUSSÃO}

4.1. Efeito das preparações das diferentes partes do cogumelo $L$. edodes, secas ou congeladas, sobre o crescimento micelial e esporulação de $E$. turcicum

Inicialmente, foram realizados testes exploratórios visando verificar a existência de algum efeito do $L$. edodes sobre o crescimento micelial e esporulação de $E$. turcicum, bem como avaliação de diferentes concentrações dos extratos e método de armazenamento dos basidiocarpos, visto que os mesmos apresentam um curto período de conservação, por volta de 14 dias como produto fresco. Assim, para manter um padrão dos basidiocarpos utilizados durante os ensaios, foi necessário a escolha de um método de preservação dos mesmos, entre os quais o congelamento ou a secagem.

Deste modo, as Tabelas 1 e 2 apresentam os resultados obtidos nos testes de armazenamento dos basidiocarpos, bem como da avaliação do efeito da concentração dos filtrados obtidos das diferentes partes do basidiocarpo (pileo e estípe) sobre o $E$. turcicum. Pode-se observar que tanto o filtrado de píleo como de estípe em concentrações superiores a $10.000 \mathrm{ppm}$ apresentam efeito inibitório do crescimento micelial e esporulação de E. turcicum. O uso de basidiocarpos congelados ou secos não alterou a inibição do crescimento micelial ou esporulação do patógeno, porem ocorreu um aumento na esporulação, quando o mesmo foi submetido a concentrações de $100 \mathrm{e}$ $1.000 \mathrm{ppm}$ dos filtrados. 

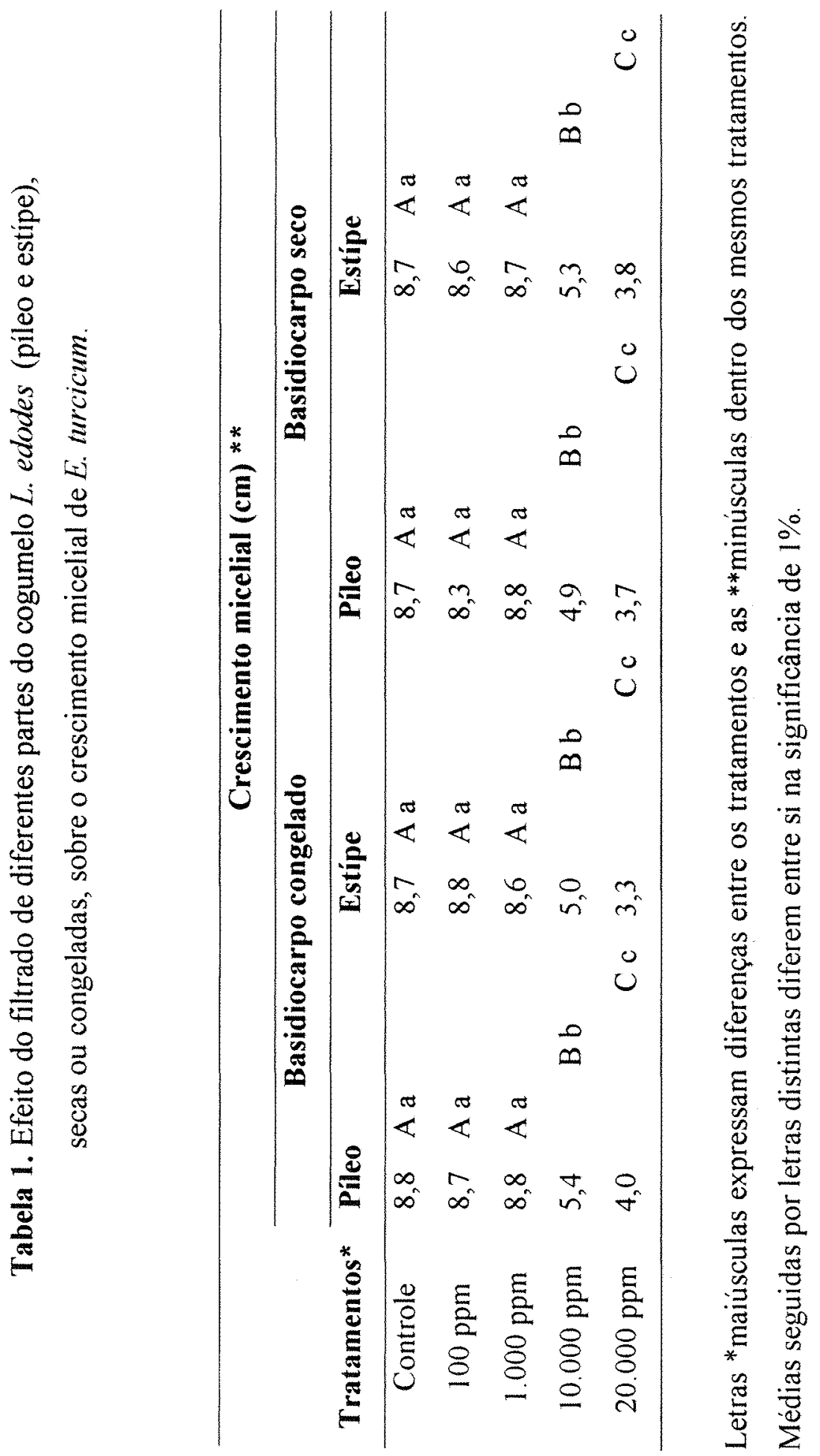


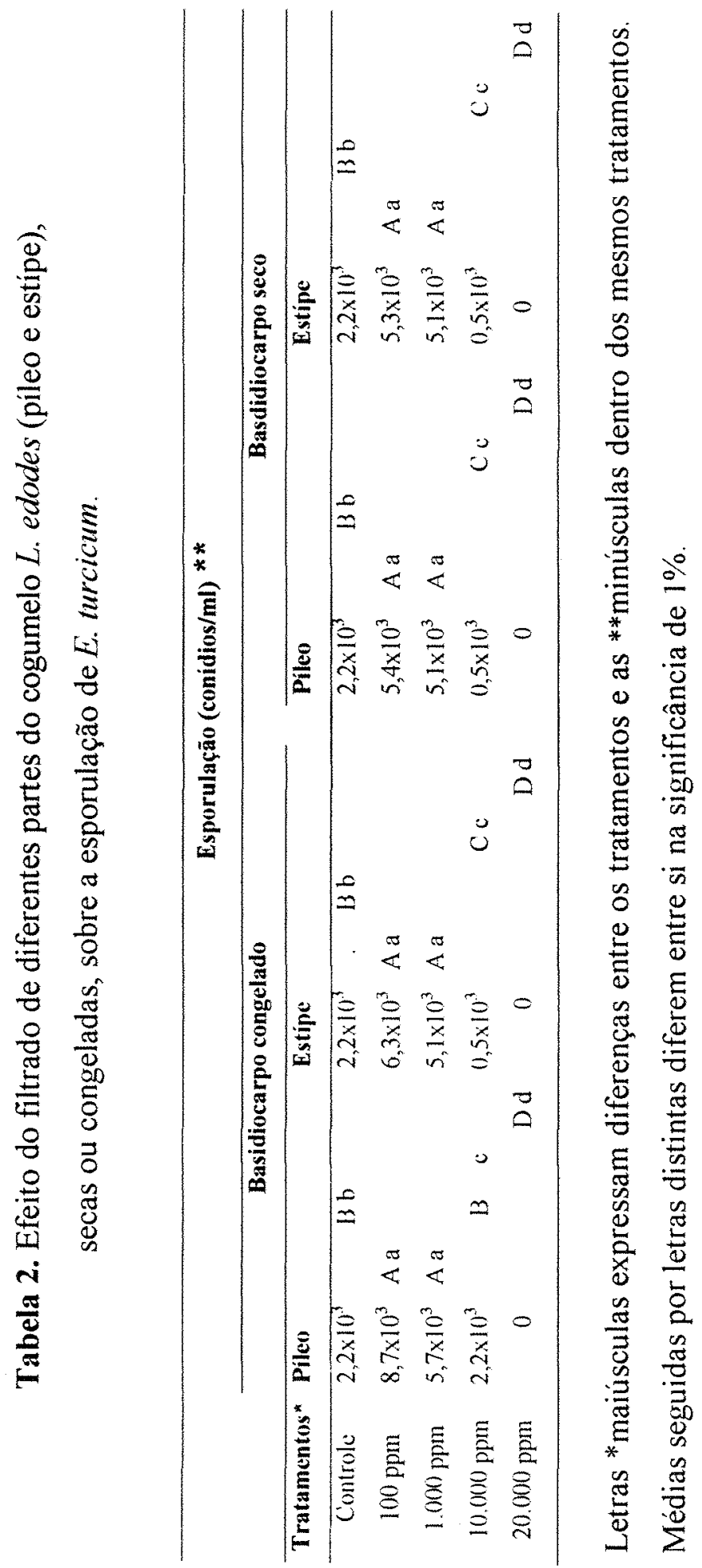


Este resultado pode ser atribuído ao possível efeito nutricional dos filtrados do basidiocarpo, visto que o cogumelo shiitake é rico em proteinas, açúcares, minerais como cálcio, ferro, fósforo e potássio, vitamina $\mathrm{D}$ e completo nas do vitaminas do complexo B (Pryzybylowics \& Donoghue, 1990). De acordo com Blakeman \& Fokonema (1982) a inibição da germinação e esporulação de microrganismos é diretamente influenciada pela competição por nutrientes, onde em ambientes com maior disponibilidade de nutrientes os processos de germinação e esporulação tendem a ser estímulados, suportando assim esta hipótese.

Para as concentrações de 10.000 e 20.000 ppm dos filtrados, apesar de ser observada uma redução do crescimento micelial de E. turcicum, não houve a morte do fungo, ocorrendo apenas um efeito de redução do crescimento micelial do $E$. turcicum (Tabela 1). Os resultados encontrados assemelham-se aos obtidos por Takazawa et al. (1982) onde os autores isolaram um potente inibidor de crescimento fúngico à partir de basidiocarpos desidratados do shiitake, porém de natureza fungistática. Na mesma linha, Paccola (1997) e Maki (1999) também demonstraram a presença de substâncias fungistáticas presentes em $L$. edodes quando aplicadas in vitro na presença de C. albicans.

Foi observada uma redução na esporulação, a partir da concentração de 10.000 ppm (Tabela 2), sendo que na concentração de 20.000 ppm observa-se a inibição total da esporulação. Esse fato provavelmente é devido ao aumento da concentração de substâncias inibidoras, suplantando um possivel efeito nutricional.

Com base nos resultados obtidos, não foi observada nenhuma diferença significativa no uso dos filtrados de pileo ou estipe, bem como de filtrados oriundos de cogumelo congelado ou seco. Desta forma, optou-se pelo uso do basidiocarpo seco nos demais ensaios, devido à maior facilidade no manuseio do mesmo em relação ao congelado. 


\subsection{Efeito das preparações do basidiocarpo seco de $L$. edodes sobre o crescimento micelial e esporulação de $E$. turcicum e $C$. sublineolum e sobre a multiplicação da bactéria $X$. campestris pv. passiflora}

Podemos observar pelas Tabelas 3, 4, 5, 6 e 7 e Figura 5, os ensaios realizados com os filtrados de basidiocarpo, píleo e estípe de $L$. edodes, onde foram analisados os efeitos dos mesmos em diferentes concentrações, sobre o crescimento micelial e esporulação de E. turcicum e C. sublineolum, e multiplicação de $X$. campestris pv. passiflora.

Nas Tabela 3 e 4 podemos observar que tanto para o crescimento micelial quanto para a esporulação, de E. turcicum, não foram observadas diferenças entre os diferentes filtrados, além de que na concentração de 20.000 ppm foi obtida a inibição completa da esporulação do patógeno, como já observado anteriormente (Tabela 2). Nas Tabelas 5 e 6 , referentes ao $C$. sublineolum, observamos resultados um pouco diferentes dos obtidos para o E. turcicum.

$\mathrm{Na}$ Tabela 5, temos que para maiores concentrações dos filtrados, ocorreram reduções crescentes do desenvolvimento micelial de C. sublineolum, assim como o observado para E. turcicum, em concordância ao observado por Piccinin \& Pascholati (1997). Por sua vez, na Tabela 6 observamos um aumento da esporulação do fungo nos tratamentos com 100 e 1.000 pm dos filtrados e uma redução da esporulação nas concentrações de 10.000 e 20.000 ppm, porém não ocorrendo a inibição completa da mesma, como foi observado para o E. turcicum.

Estas diferenças entre E. turcicum e $C$ sublineolum no tocante à esporulação, talvez possam ser explicadas pela maior ou menor sensibilidade dos patógenos aos filtrados das diferentes preparações do basidiocarpo ou ainda devido a fatores, como a maior capacidade de esporulação do $C$. sublineolum em relação ao $E$. turcicum, semelhante ao que ocorre para a resistência a fungicidas, onde quanto maior a esporulação, maiores as chances de sobrevivência do patógeno, ou ainda devido a fatores naturais de resistência dos patógenos aos filtrados (Tokeshi, 1991). 


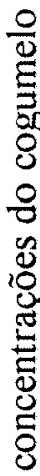

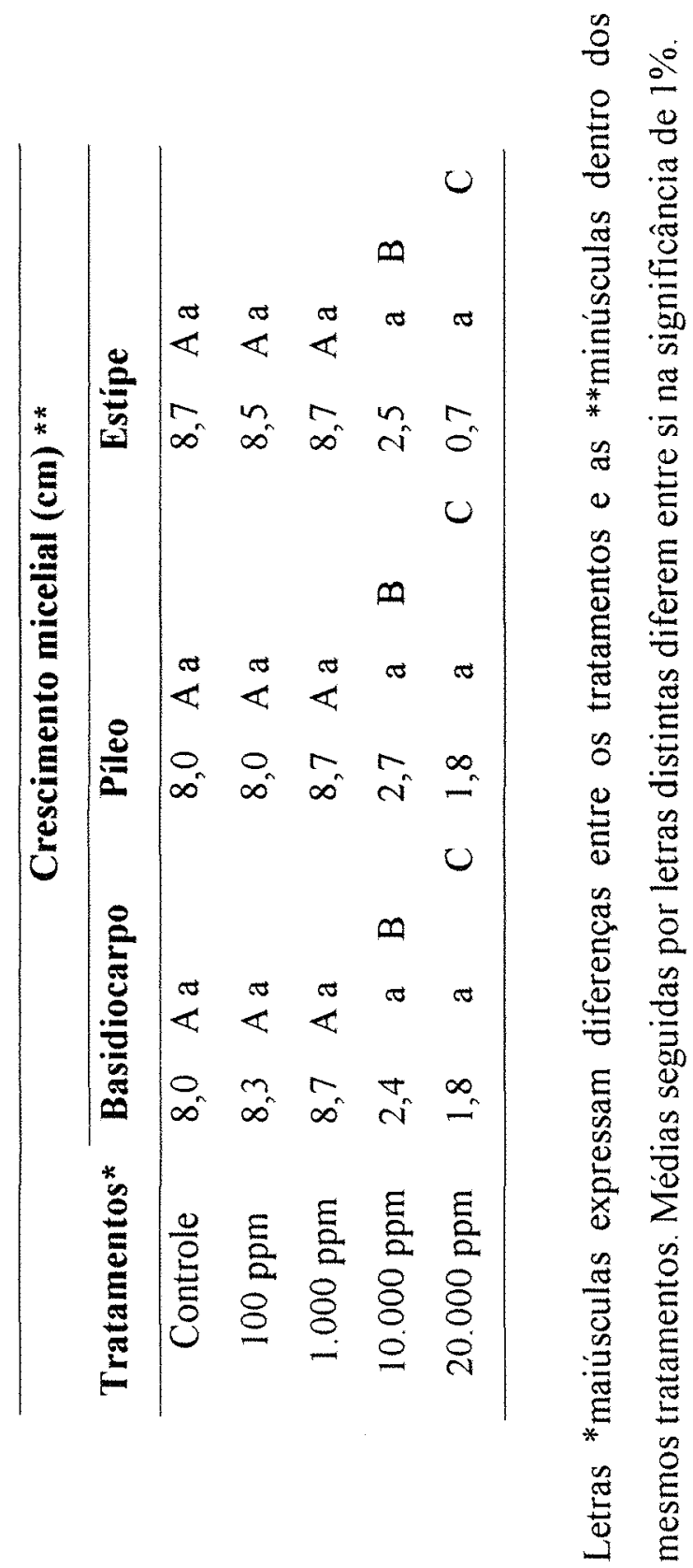



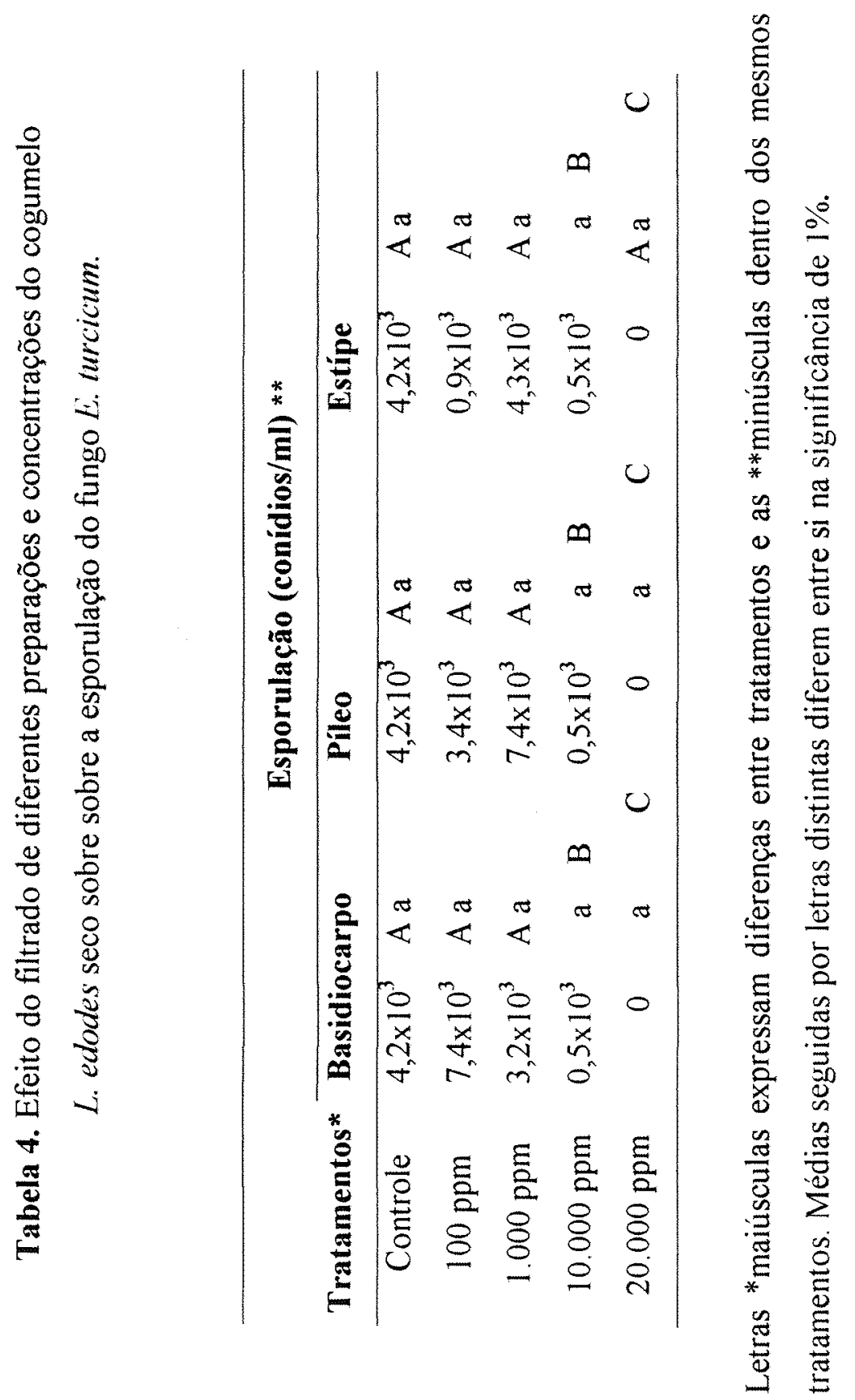


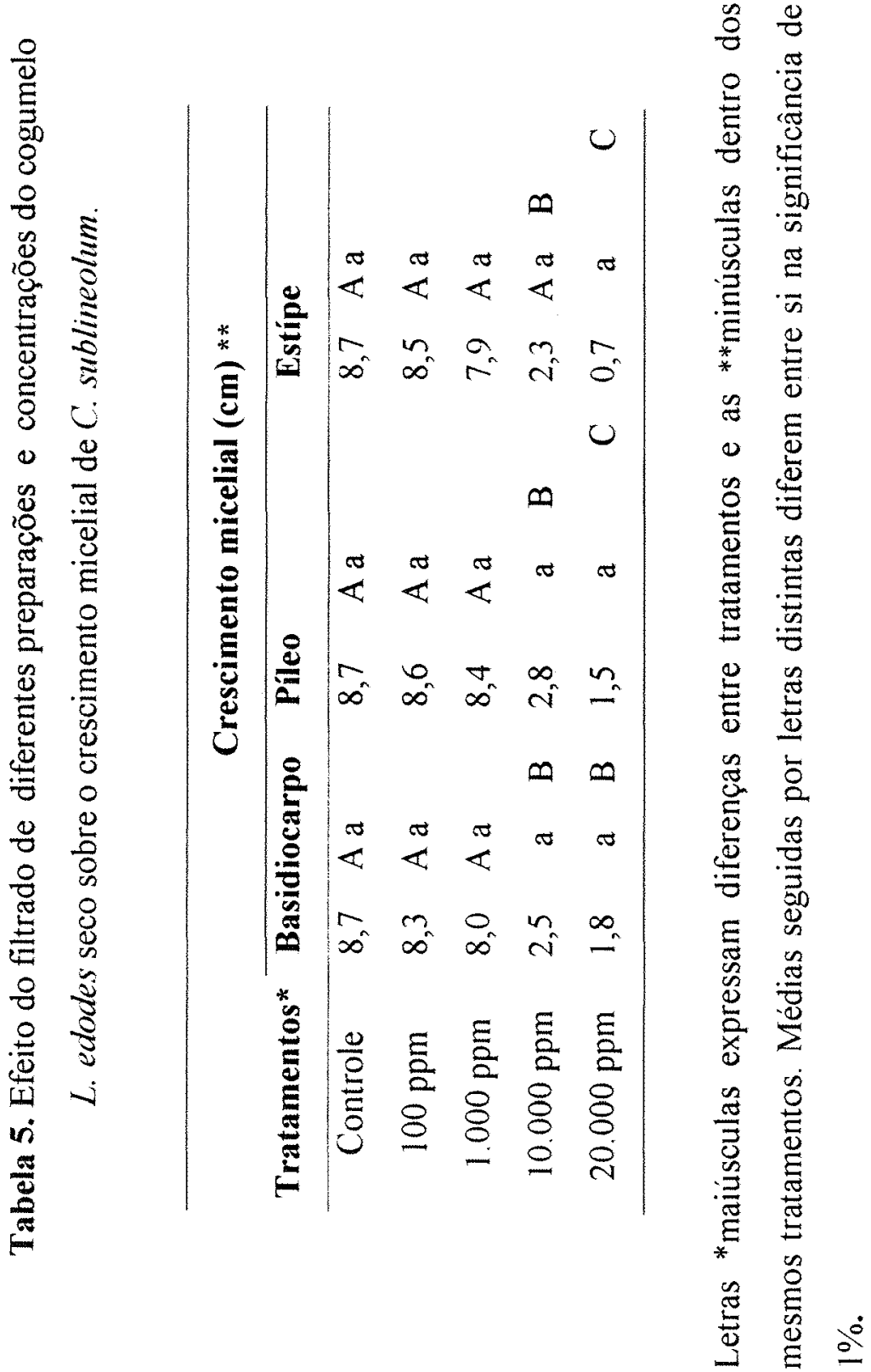



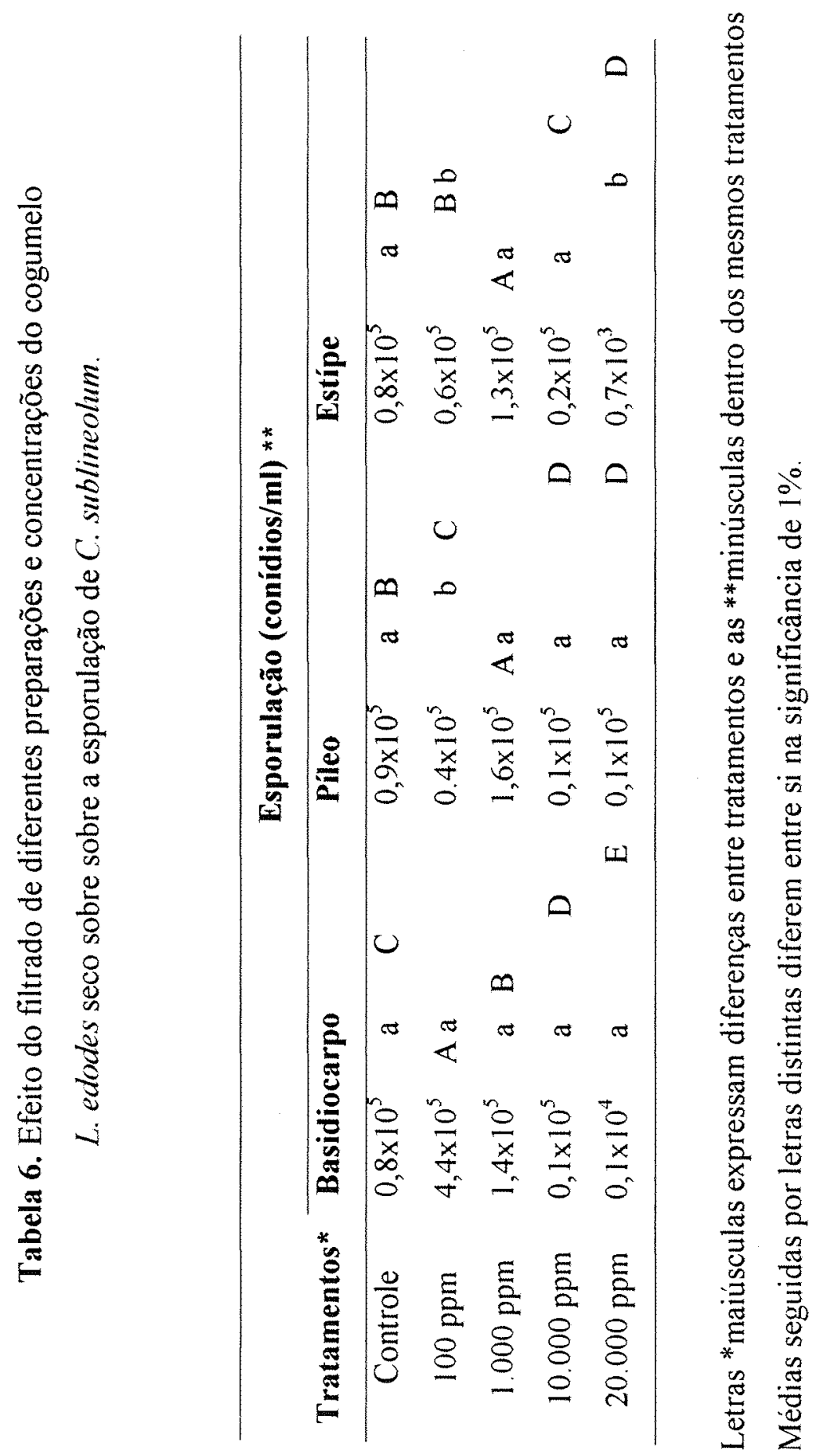


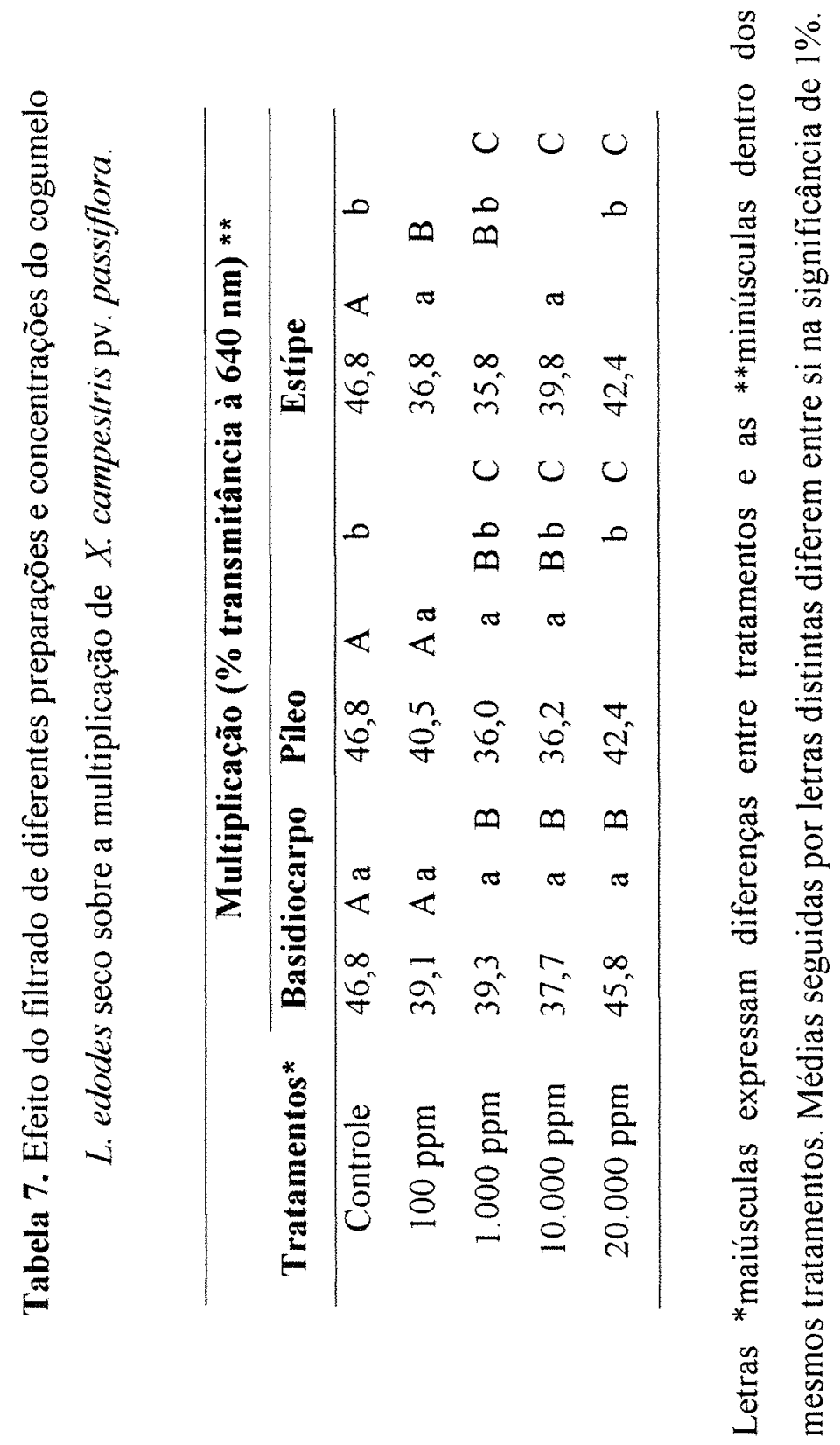


Pode-se observar pelas Tabelas 3, 4, 5 e 6 que não ocorreram diferenças significativas entre os diferentes filtrados (basidiocarpo, pileo e estípe). dentro do mesmo tratamento, para os fungos E. turcicum e C. sublineolum, tanto na redução do crescimento micelial e a esporulação, exceto na Tabela 6 onde a estípe apresentou maior redução da esporulação em relação aos demais filtrados, quando utilizada na concentração de 20.000 ppm.

Porém devido à pequena quantidade de estípe produzida pelo shiitake, em torno de $23,35 \%$ do total do basidiocarpo seco, e devido à pequena diferença numérica existente entre os resultados, apesar de os resultados serem estatisticamente diferentes, optou-se pelo uso de filtrados do basidiocarpo seco, nos ensaios com fitopatógenos fúngicos ao invés dos filtrados de estípe, ou píleo, visando facilitar o preparo de maiores volumes do filtrado para os experimentos com plantas.

$\mathrm{Na}$ Tabela 7 podemos observar que para a bactéria $X$. campestris $\mathrm{pv}$. passiflora, os filtrados das diferentes preparações de $L$. edodes atuaram estimulando o crescimento bacteriano (menores valores de transmitância), em desacordo aos resultados obtidos por Hirasawa et al. (1999).

Esse efeito estimulador do crescimento bacteriano, talvez possa ser explicado devido a concentração de vitaminas do complexo B e proteínas existentes no basidiocarpo e possivelmente nos diferentes filtrados (Pryzybylowics \& Donoghue, 1990) visto estas substâncias serem essenciais ao crescimento das bactérias e poderem atuar estimulando a multiplicação das mesmas (Blakeman \& Fokkema, 1982).

Uma outra hipótese é a possibilidade dos compostos presentes no extrato aquoso do basidiocarpo serem termolábeis, como já demonstrado por Hirasawa et al. (1999). Durante o processo de incorporação dos mesmos ao meio de cultura ainda quente, poderia ter ocorrido a perda da propriedade anti-bacteriana em função de calor. 


\subsection{Efeito da autoclavagem e congelamento das preparações de basidiocarpo seco} de $L$. edodes, na concentração de $20.000 \mathrm{ppm}$, sobre o crescimento micelial e esporulação de E. turcicum e C. sublineolum

Pelos resultados obtidos nas Tabelas 8 e 9 observamos que quando os filtrados de basidiocarpo foram autoclavados (filtrado autoclavado de basidiocarpo), os mesmos sofreram alteração na capacidade de redução do crescimento micelial e esporulação de E. turcicum e C. sublineolum, indicando assim a uma possível atividade antifúngica de natureza termolábil, de acordo com o observado por Maki (1999) utilizando de preparações de shiitake para o controle de Helminthosporium. Porém, apesar da perda de atividade deste filtrado após a autoclavagem, os resultados observados na redução do crescimento micelial e esporulação, dos patógenos de $E$. turcicum e C. sublineolum (Tabelas 8 e 9), são melhores estatisticamente que os resultados obtidos no controle. O que nos leva à hipótese de que a substância antimicrobiana presente no filtrado não foi totalmente inativada durante a autoclavagem, ou então, que a temperatura de inativação do mesmo está próxima a temperatura de autoclavagem. Considerando que a temperatura utilizada na autoclavagem estivesse próxima ao ponto de inativação térmica da substância antimicrobiana, seria possivel a ocorrência de uma destruição parcial da mesma, ocasionando um menor controle dos microrganismos testados, em comparação ao mesmo filtrado sem a autoclavagem (filtrado de basidiocarpo).

Entretanto a eficiência do filtrado de basidiocarpo autoclavado é questionável (Tabelas 8 e 9), visto que o referido filtrado apresentou melhor eficiência no controle do crescimento micelial de E. turcicum e C. sublineolum e melhor controle da esporulação de C. sublineolum, em relação aos demais tratamentos, em desacordo ao obtido para o filtrado autoclavado de basidiocarpo. Neste caso, deve-se lembrar que, o filtrado de basidiocarpo autoclavado, foi preparado autoclavando-se o basidiocarpo do shiitake, e o filtrado autoclavado de basidiocarpo, foi preparado mediante a autoclavagem do filtrado de basidiocarpo. Deste modo, o basidiocarpo poderia ter atuado como um isolante térmico da substância presente no cogumelo, protegendo-a de um aquecimento excessivo. 


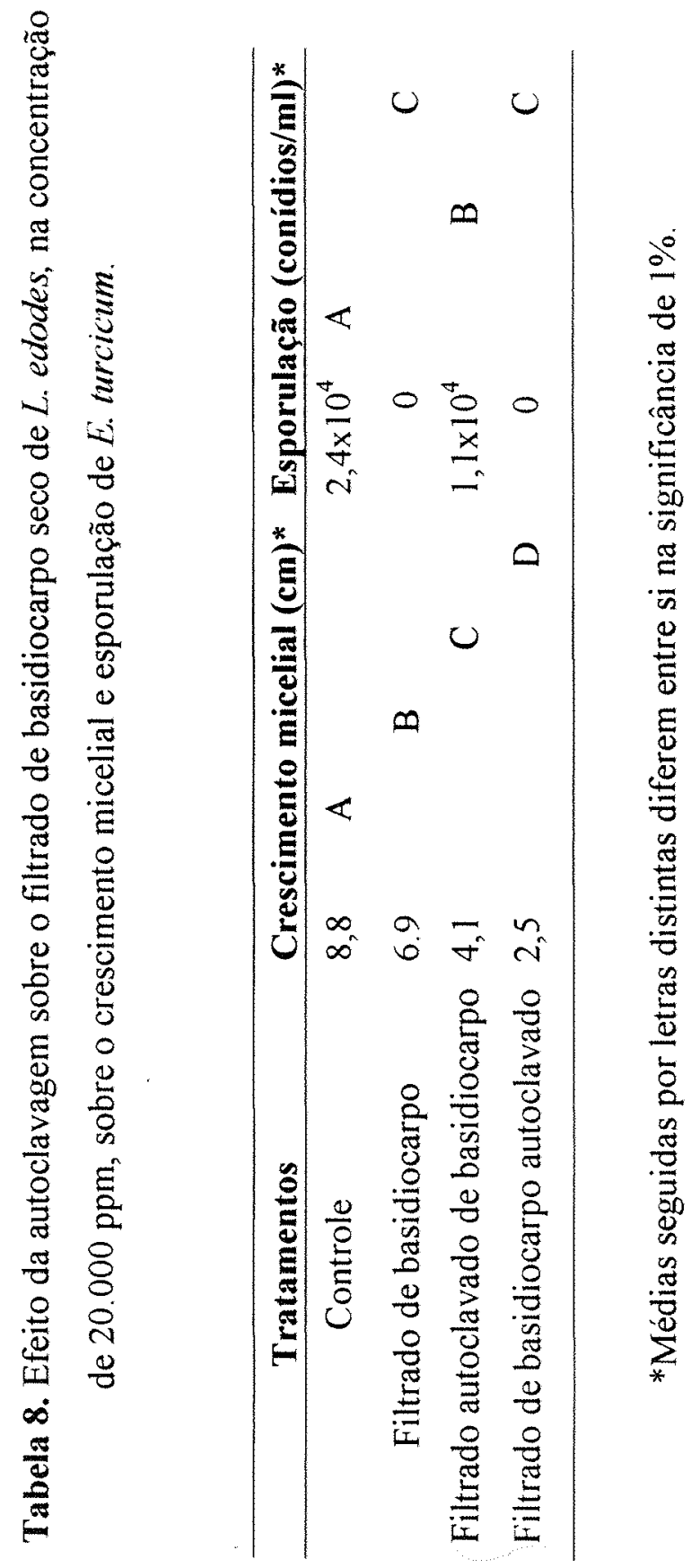




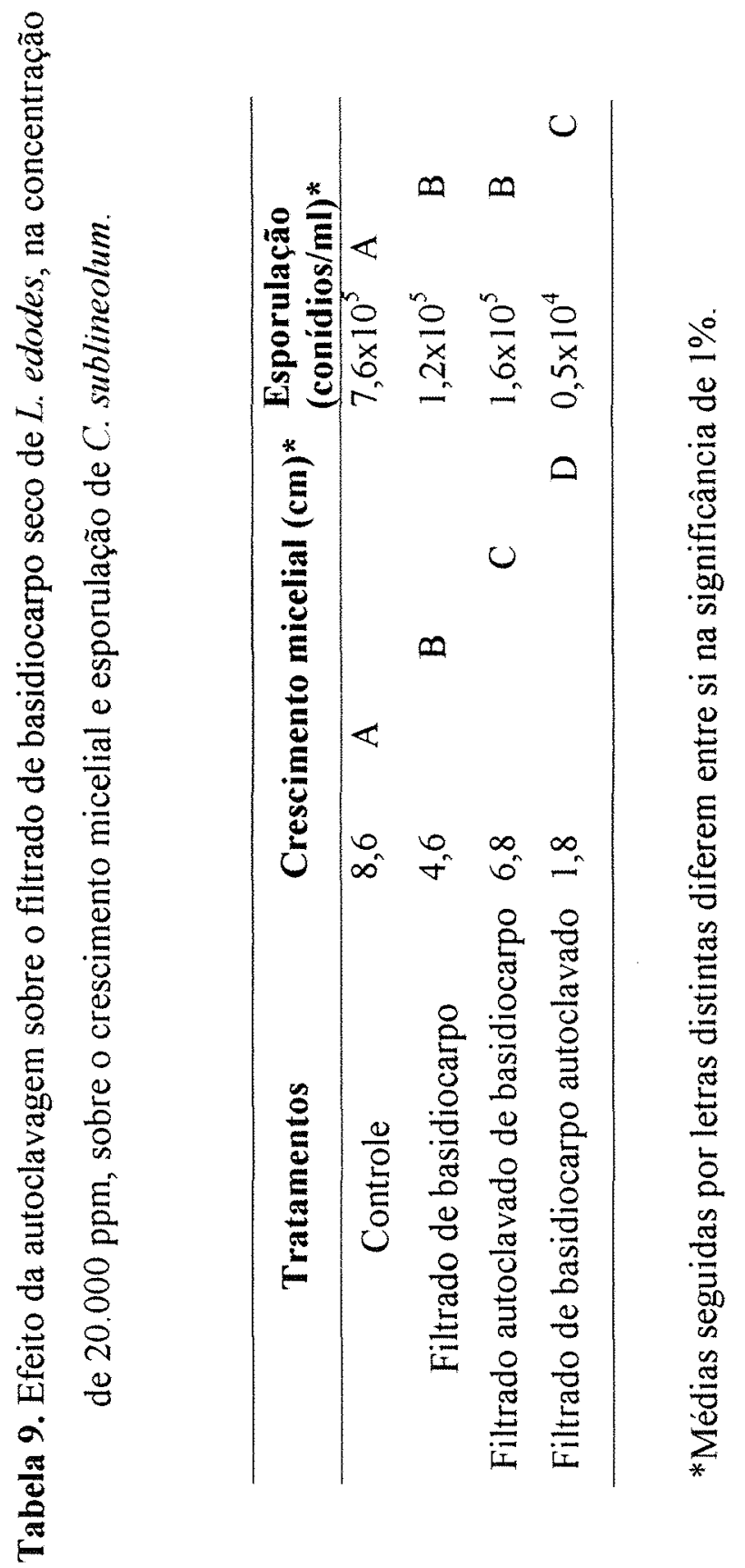


Esta hipótese pode ser confirmada pela Tabela 10, onde o filtrado de basidiocarpo autoclavado, quando submetido a nova autoclavagem perde parcialmente $o$ efeito no controle do crescimento micelial. E observando-se novamente a Tabela 2, temos que quando píleo e estípe foram submetidos ao congelamento, os mesmos preservaram o efeito antimicrobiano de seus filtrados. Porém, quando observamos a Tabela 10 , temos que o filtrado de basidiocarpo após o congelamento perde seu efeito na redução do crescimento micelial e esporulação de $E$. turcicum. Reforçando assim a hipótese de termo proteção conferida pelo basidiocarpo.

A a maior eficiência do filtrado de basidiocarpo autoclavado no controle do crescimento micelial, observado nas Tabelas 8,9 e 10 em relação aos demais tratamentos não está esclarecida, pois era esperado que o mesmo tivesse ação semelhante ao filtrado de basidiocarpo e não superior ao mesmo, caso não ocorresse inativação térmica das substâncias antimicrobianas. Uma das hipóteses para justificar esse fato seria o aumento da solubilidade da substância antimicrobiana presente no basidiocarpo, quando o mesmo é submetido à autoclavagem. Desta forma, essa substância estaria em concentração superior no filtrado de basidiocarpo autoclavado, em relação aos demais filtrados. Assim sendo, teríamos um maior controle do crescimento micelial e esporulação dos fitopatógenos testados, mesmo com a inativação térmica parcial da substância antimicrobiana do filtrado.

Observando-se a Tabela 10, encontramos que o filtrado de basidiocarpo autoclavado perde o efeito no controle do crescimento micelial de E. turcicum quando submetido à nova autoclavagem, indicando que a natureza do filtrado é do tipo termolábil. A esporulação do fungo para o mesmo tratamento, no entanto continua sendo zero, o que leva a hipótese da presença de 2 grupos de compostos, um termolábil atuando sobre o crescimento micelial e outro termoresistente, reduzindo a esporulação (Tabela 10). No entanto a hipótese apresentada não consegue explicar o porquê da diferença na esporulação entre o filtrado de basidiocarpo autoclavado e demais filtrados (Tabela 8). 


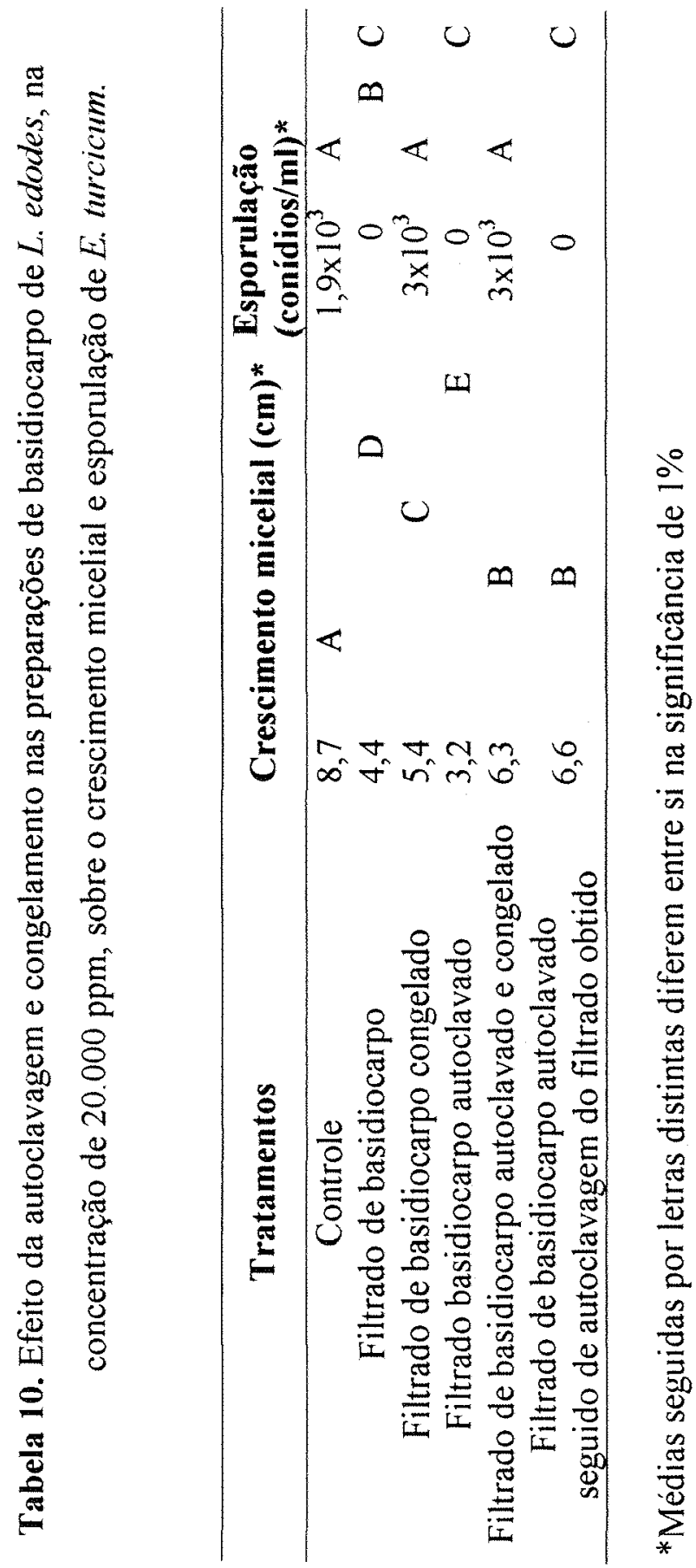


Deste modo voltamos à hipótese anteriormente levantada sobre um possível ponto de inativação térmica das substâncias antimicrobianas próximo à temperatura de autoclavagem, onde pode-se propor a hipótese de que a substància inibidora do crescimento micelial apresenta uma maior sensibilidade ao calor em relação à inibidora da esporulação.

Observando-se a Tabela 11, podemos levantar uma nova hipótese, a de que a autoclavagem do basidiocarpo seria responsável pela liberação de algum outro produto antibiótico, insolúvel em água. Porém no tratamento com a mistura dos filtrados de basidiocarpo e basidiocarpo autoclavado, eram esperadas diferenças significativas entre os demais tratamentos, pois esperava-se um resultado intermediário entre filtrado de basidiocarpo e filtrado de basidiocarpo autoclavado, contudo isto não foi observado. Descartando praticamente a hipótese de liberação de uma nova substância durante a autoclavagem.

Através da Tabela 11 pode-se observar também as substâncias presentes nos filtrados de basidiocarpo, apesar de serem termolábeisnão são destruídas a baixa temperatura de incorporação dos filtrados ao meio de cultura, que está por volta de $45^{\circ} \mathrm{C}$. Deste modo, reforça a hipótese de que as substâncias presentes no cogumelo comecem a ser inativadas em temperaturas mais elevadas. Além da hipótese da interferência do corpo de frutificação atuando como um termo protetor.

\subsection{Efeito das preparações de $L$. edodes e do aquecimento dos mesmos à $45^{\circ} \mathrm{C}$, sobre a multiplicação de $X$. campestris pv, passiflora}

Apesar dos resultados iniciais de incorporação dos filtrados de $L$. edodes em meio de cultura não apresentarem efeito acentuado sobre a multiplicação de $X$. campestris pv. passiflora (Tabela 7), novos ensaios foram conduzidos visando comprovar se a temperatura de incorporação dos filtrados do basidiocarpo ao meio fundente poderia estar atuando negativamente sobre o controle das bactérias, inativando os filtrados. 


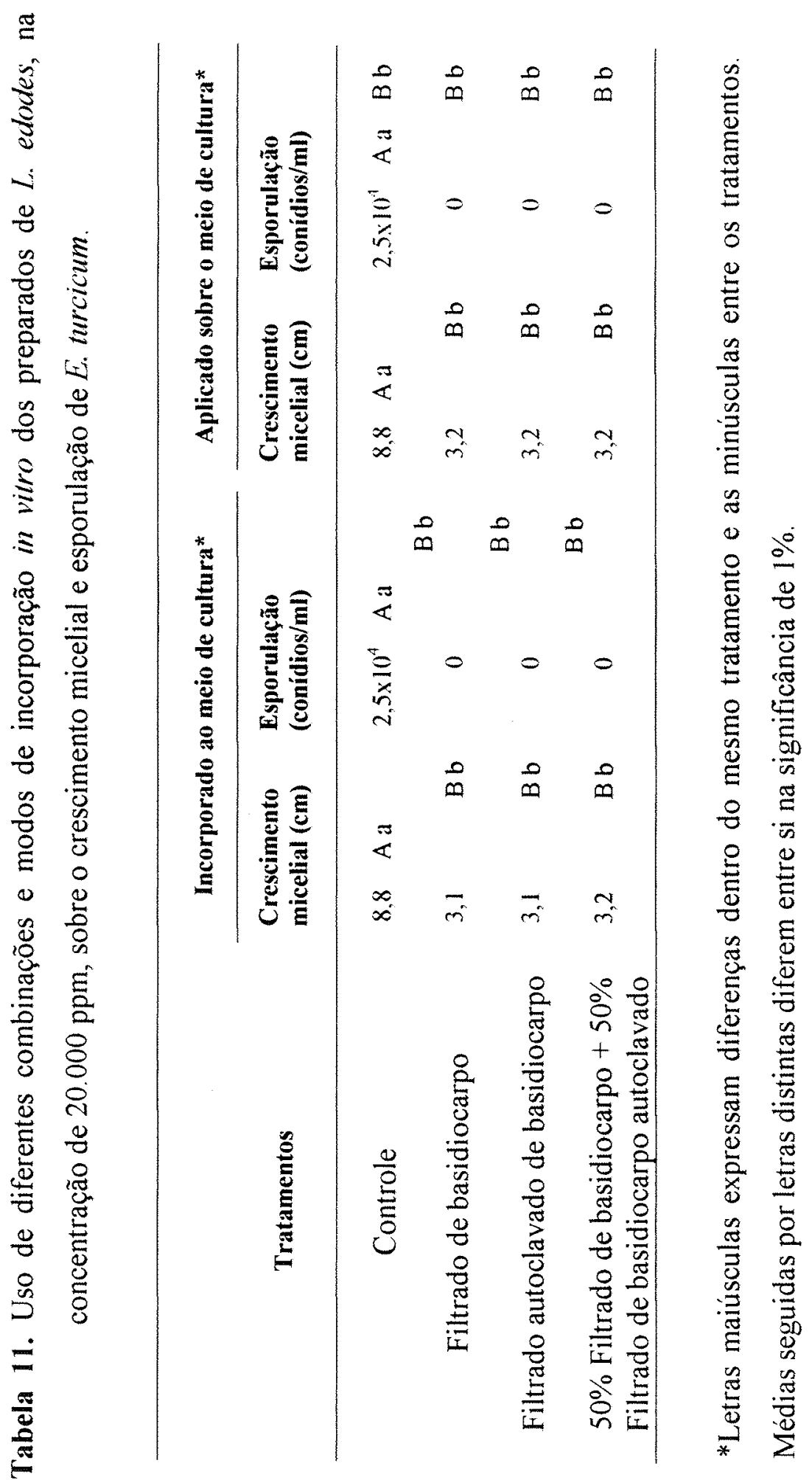


Os ensaios foram realizados em tubos de ensaio contendo as suspensões bacterianas mais os diferentes filtrados. Foram realizados ensaios preliminares visando 0 desenvolvimento de metodologia de incorporação a frio dos filtrados de $L$. edodes para o controle de $X$. campestris pv. passiflora. Para tanto, foram preparados tubos de ensaio contendo água ou meio líquido batata dextrose, mais suspensão bacteriana. Após 24 horas, foi observado que não existiam diferenças estatísticas entre os tratamentos água e $\mathrm{BD}$, mais suspensão bacteriana.

Porém, quando adicionou-se o filtrado de estípe nos tubos contendo água ou meio batata dextrose, mais suspensão bacteriana, observou-se que no tratamento com o filtrado de estípe mais o meio batata dextrose e suspensão bacteriana, a multiplicação bacteriana foi superior estatisticamente a todos os demais tratamentos, inclusive ao tratamento contendo meio batata dextrose e suspensão bacteriana. Deste modo, pode ser observada uma ação sinergística entre o meio de cultura, mais o filtrado de estípe do $L$. edodes, o que provavelmente pode ter ocasionada devido a uma complementação nutricional do meio de cultura com o preparado do basidiocarpo.

Com base no exposto, optou-se pela realização de todos estes ensaios em tubos de ensaio, utilizando-se da suspensão bacteriana preparada em água mais os preparados de $L$ edodes. Pela Tabela 12 e Figura 6 , podemos observar que os filtrados de basidiocarpo, píleo e estípe reduzem a multiplicação das bactérias quando incorporados em água e não aquecidos. Verificou-se, também, que o efeito dos filtrados de basidiocarpo e píleo são do tipo bacteriostáticos, pois as bactérias atrasavam o crescimento, porém voltavam a crescer no mesmo meio de cultura após algum tempo, e o filtrado de estípe bactericida, pois mesmo com o preparo de novas repicagens a partir deste tratamento para novo meio $\mathrm{BDA}$, não foi observado crescimento bacteriano, indicando a morte da bactérias.

Após um leve aquecimento à $45^{\circ} \mathrm{C}$, os filtrados perdem o efeito. $\mathrm{O}$ filtrado de estípe passou de bactericida a bacteriostático, enquanto que ocorreu a perda da eficiência no controle das bactérias para os filtrados de píleo e basidiocarpo (Tabela 12). 
Tabela 12. Efeito de diferentes filtrados de $L$. edodes, a concentração de $20.000 \mathrm{ppm}$, e do aquecimento dos mesmos à $45^{\circ} \mathrm{C}$, sobre a multiplicação de $X$. campestris pv passiflora.

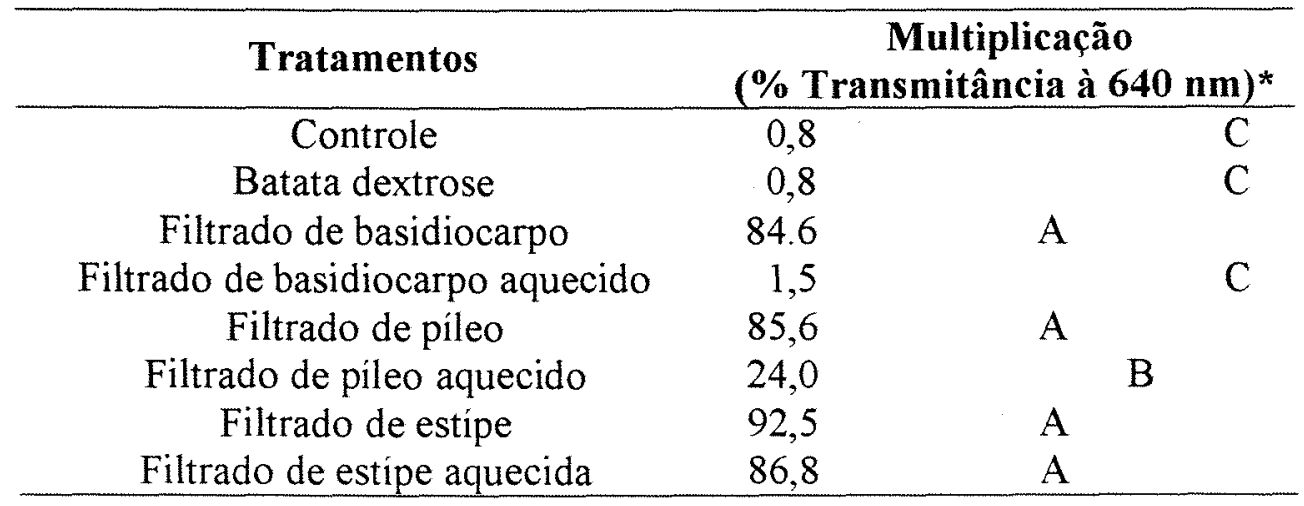

*Médias seguidas por letras distintas diferem entre si na significância de $1 \%$ 
Hirasawa et al. (1999) encontraram que os filtrados de L. edodes solúveis em água e com efeito antibacteriano eram termolábeis a partir de pequeno aquecimentos. Estes resultados demonstraram que a metodologia de incorporação de preparados de $L$. edodes em meio de cultura (Tabela 7) não são adequados para este tipo de ensaio.

\subsection{Efeito do tempo de armazenamento das preparações de basidiocarpo de $L$. edodes em geladeira, e seu efeito no crescimento micelial e esporulação de $E$. turcicum}

Com o objetivo de se armazenar os preparados de basidiocarpo, foi realizado um ensaio visando a manutenção do material em geladeira, durante um período de 120 dias. Embora o congelamento das preparações tenha sido inviável (Tabela 10), os resultados obtidos pelo armazenamento em geladeira, evidenciam que não existem diferenças no crescimento micelial e esporulação de E. turcicum, quando da utilização de filtrados de basidiocarpo de $L$. edodes recém preparados em comparação a aqueles mantidos sob refrigeração à $4{ }^{\circ} \mathrm{C}$ por um período de 120 dias (Tabela 13).

Deste modo, foi possivel o preparo de grandes volumes de filtrado, para cada uma das diferentes preparações, e padronização dos ensaios, bem a repetição dos mesmos com preparações semelhantes, reduzindo possíveis diferenças ou erros metodológicos.

4.6. Efeito dos filtrados de crescimento micelial de $L$. edodes sobre o crescimento e esporulação de $E$. turcicum e $C$. sublineolum e multiplicação de $X$. campestris pv. passiflora

O efeito dos filtrados obtidos do meio líquido de crescimento micelial do cogumelo shiitake foram testados contra os patógenos E. turcicum, C. sublineolum e $X$. campestris pv. passiflora, sendo os resultados podem ser observados nas Tabelas 14,15 , 16 e 17. 


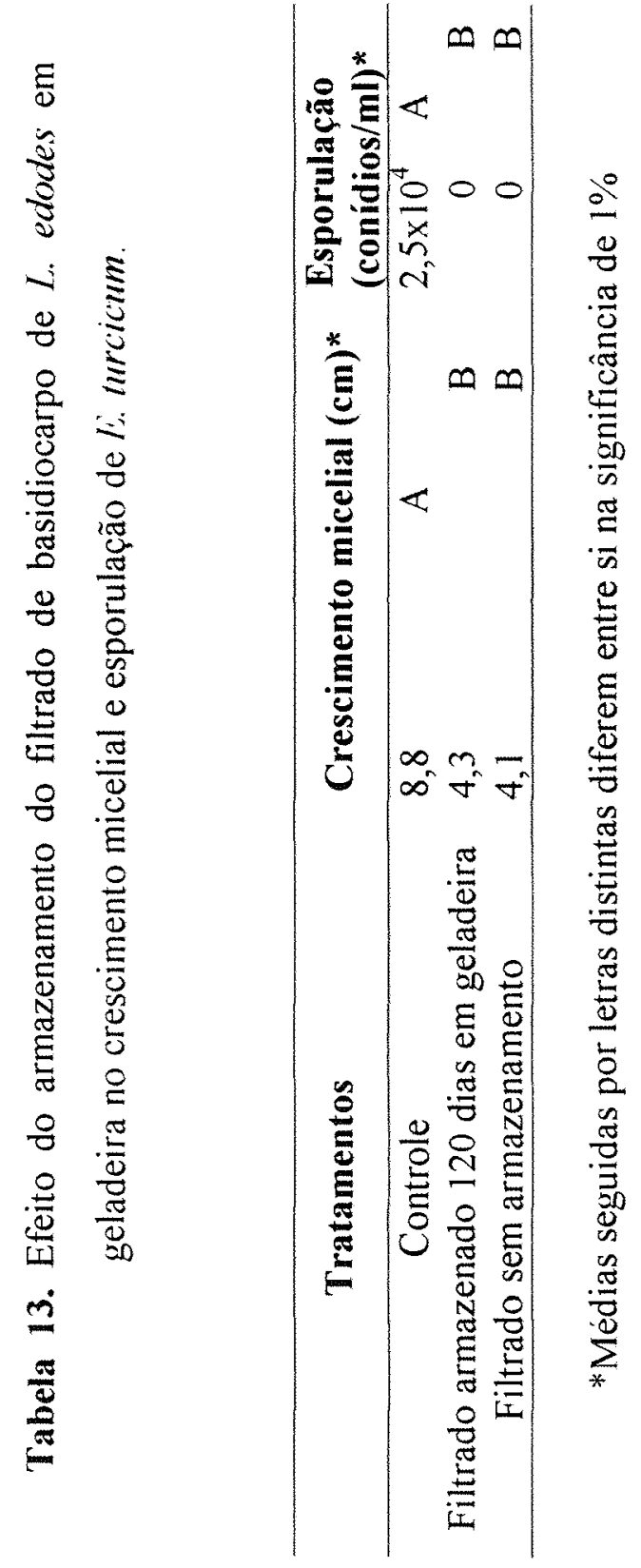



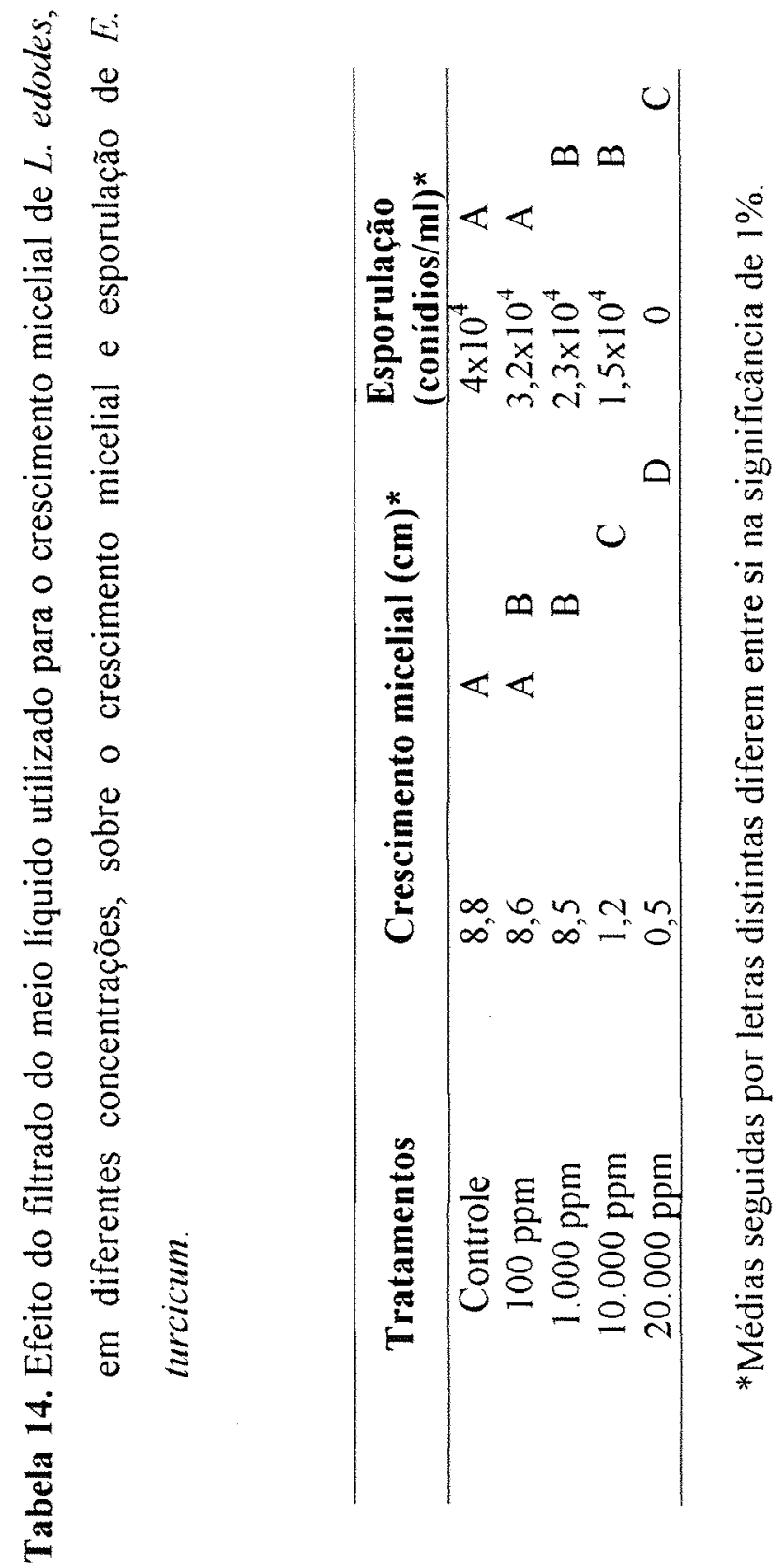


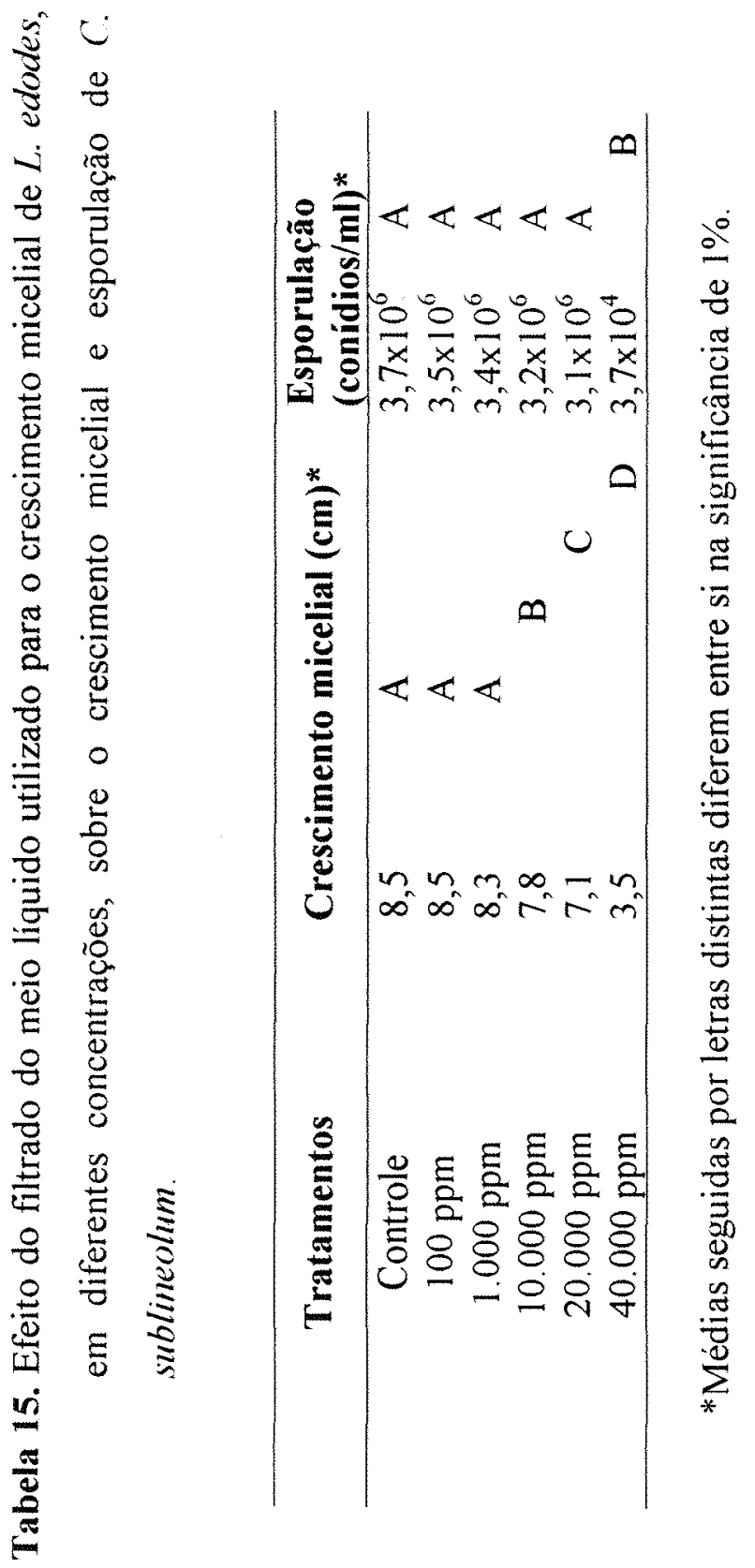




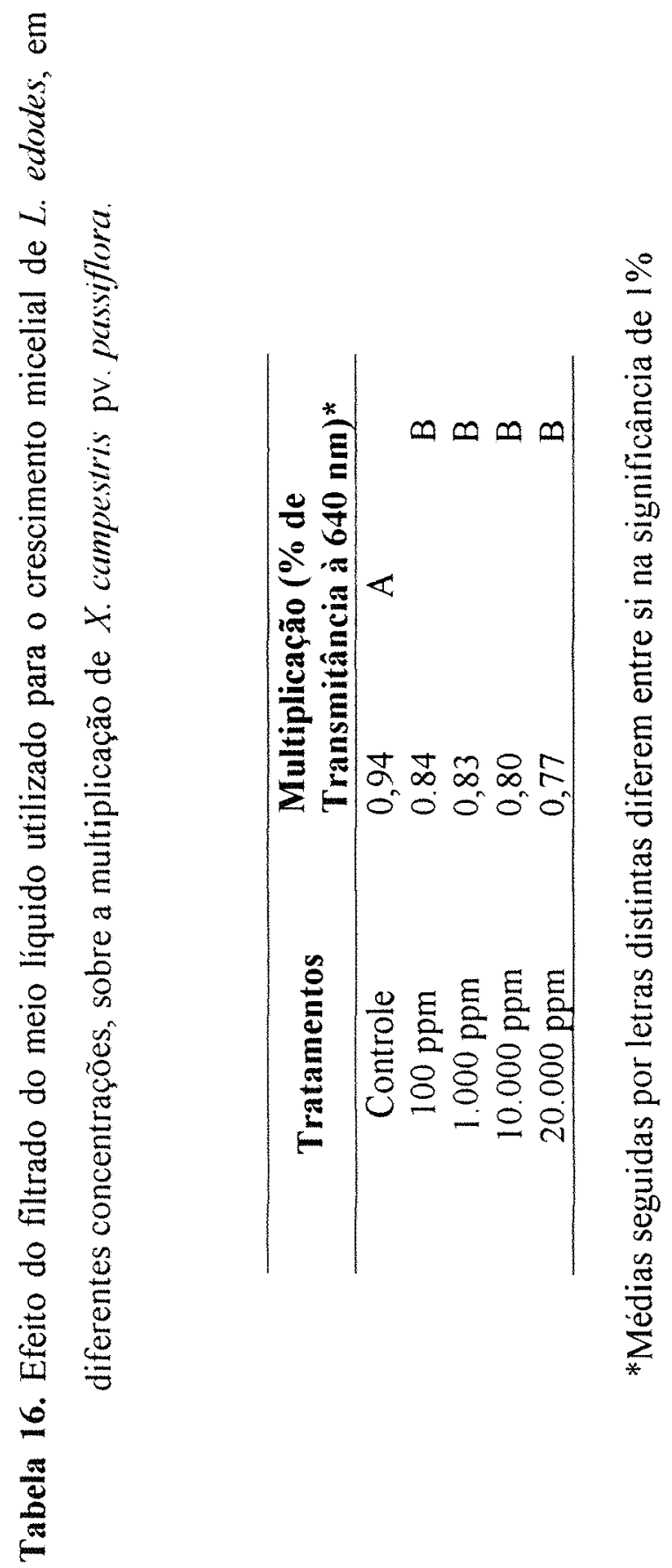



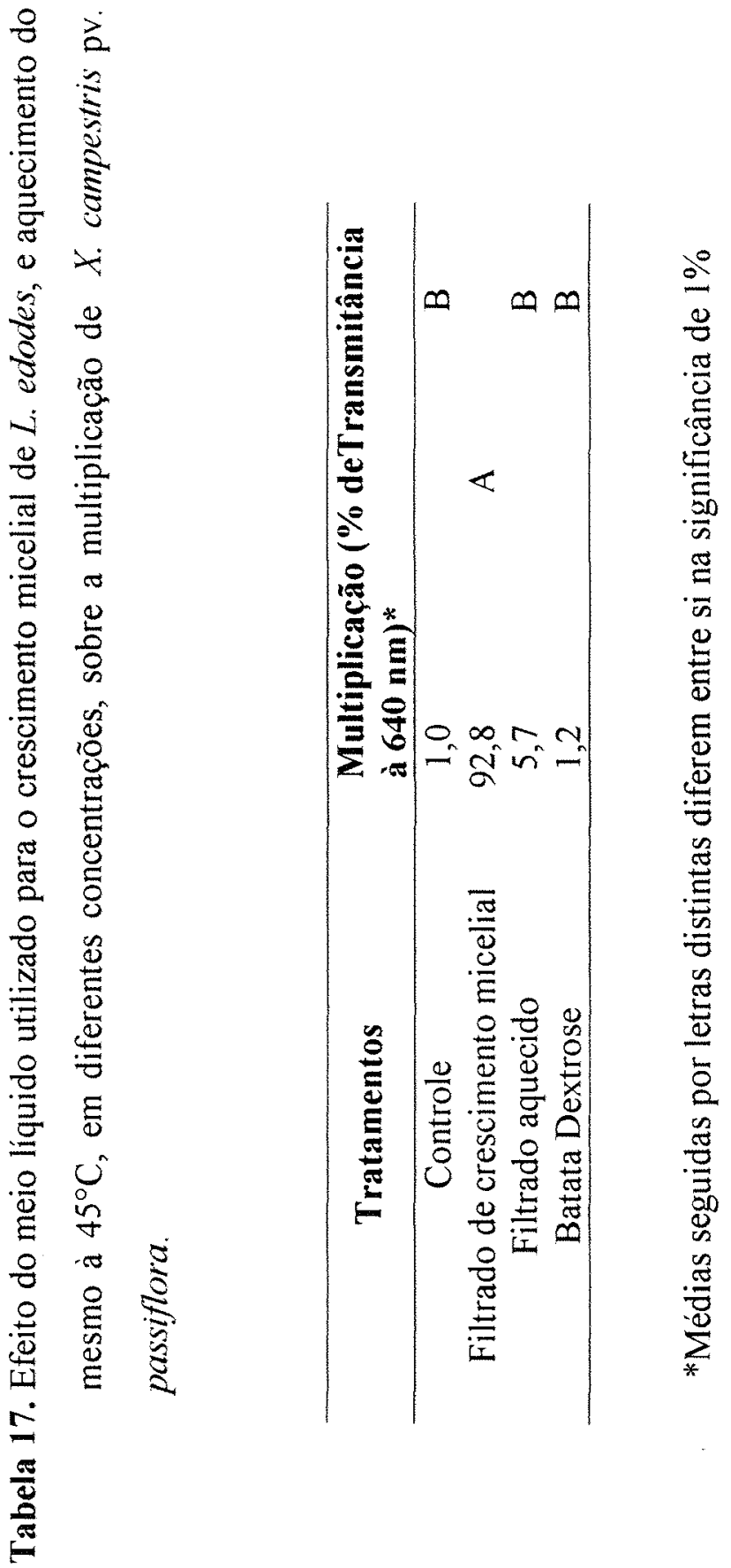
Observando-se a Tabela 14 , temos que o filtrado de crescimento micelial de $L$. edodes ocasionou uma redução do crescimento micelial e inibição completa da esporulação do patógeno E. turcicum, exercendo inclusive um efeito fungicida sobre o patógeno e não apenas fungistático como as demais preparações de L. edodes. Contudo, este mesmo filtrado de crescimento micelial quando utilizado com C. sublineolum, não apresentou redução do crescimento micelial e da esporulação fúngicas (Tabela 15). O efeito do filtrado somente foi possivel de ser observado em concentrações de 40.000 ppm (Tabela 15 e Figura 7), além de que o efeito exercido sobre o patógeno foi do tipo fungistático, (com redução do crescimento micelial e espoprulação e retomada do crescimento normal e esporulação quando colocado em meio BDA). Esses resultados demonstram que o filtrado de crescimento micelial tem efeito variável conforme o fungo utilizado, assim como já demonstrado para os demais filtrados obtidos de basidiocarpo de L. edodes.

$\mathrm{Na}$ Tabela 16 podemos observar que apesar de todas as concentrações do filtrado de crescimento micelial serem estatisticamente melhores que o controle, para a redução da multiplicação da bactéria $X$. campestris pv. passiflora, estes resultados são pouco expressivos visto que, estes valores de transmitância indicam a presença de muitas células bacterianas.

Porém, na Tabela 17 podemos observar que o filtrado de crescimento micelial quando adicionado sem aquecimento, apresentou efeito bactericida, concordando com os resultados obtidos por Pacumbaba (1999) usando filtrados de crescimento micelial, obtidos de substrato de cultivo do cogumelo shiitake, no controle das bactérias fitopatogènicas $P$. solanacearum e $X$. campestris pv. vesicatoria.

No entanto, com o aquecimento do filtrado de crescimento micelial à $45^{\circ} \mathrm{C}$, o efeito foi completamente perdido, indicando que o mesmo é termolábil, a baixas temperaturas de aquecimento. Esses resultados diferem em parte dos resultados obtidos por Hirasawa et al. (1999) que verificaram a presença de substâncias do tipo termolábil para os extratos aquosos do cogumelo, porém o efeito destes extratos foram apenas bacteriostáticos e não bactericidas como os encontrados (sem crescimento bacteriano após a repicagem para meio $\mathrm{BDA}$ ). 
Deve-se lembrar que Hirasawa et al. (1999) utilizaram bactérias causadoras de infecções bucais, o que pode gerar esta discrepâncias com relação ao efeito bactericida ou bacteriostático dos filtrados.

Bianco (1981) relatou que o L. edodes possui substâncias com elevada atividade antibiótica a bactérias gram positivas e negativas, e sugeriu que uma das principais substâncias antibacterianas produzidas pelo cogumelo é a cortinelina. Por sua vez, Hobbs (1996) e Komemushi (1996) na mesma linha, encontraram outra substância de efeito antibacteriano, a eritadenina ou lentinacin, que difere da cortinelina, pois a mesma é obtida através de extração etanólica.

\subsection{Efeito do lentinan sobre a multiplicação de $X$. campestris pv. passiflora.}

Devido à pequena quantidade de lentinan disponivel, foram realizados testes apenas com a dosagem de $20.000 \mathrm{ppm}$ do produto, a fim de se verificar a existência de efeito do mesmo sobre a multiplicação de $X$. campestris pv. passiflora.

Os resultados obtidos podem ser observados na Tabela 18, onde é evidente a inexistència de efeito do lentinan sobre a $X$. campestris $\mathrm{pv}$. passiflora. Com base na literatura, era esperado que o lentinan atuasse diretamente no controle bacteriano, conforme descrito por Jong \& Birminghan (1993) os quais citam que o lentinan exerceu controle sobre Pseudomonas aureaginosa, Klebsiella pneumonia e Escherichia coli.

Porém visto que as bactérias não serem fitopatogênicas, essa poderia ser a causa desta diferença nos resultados. Por outro lado, Kanai et al. (1980) e Suzuki et al (1994) citam o lentinan como um potencializador ou ativador do sistema de defesa em humanos, podendo-se pressupor que o mesmo não age diretamente sobre 0 microrganismo, mas induz a uma resposta imune (Suzuki et al., 1979). 
Tabela 18. Efeito do lentinan, na concentração de 20.000 ppm, sobre a multiplicação de $X$. campestris pv. passiflora.

\begin{tabular}{clc}
\hline Tratamentos & \multicolumn{2}{l}{$\begin{array}{l}\text { Multiplicação (\% de } \\
\text { Transmitância à } \mathbf{6 4 0} \mathbf{~ n m})^{*}\end{array}$} \\
\hline Controle & 0,92 & $\mathrm{~A}$ \\
Lentinan & 0,89 & $\mathrm{~A}$ \\
\hline
\end{tabular}

* Médias seguidas por letras distintas diferem entre si na significância de $1 \%$ 
Com base nestas informações, os resultados obtidos com X. c. campestris pv. passiflora, estariam dentro do esperado, ou seja o lentinan não atuaria diretamente sobre o microrganismo. E com relação à possibilidade do lentinan ser termolábil, podemos concluir que devido à natureza da molécula, esta hipótese pode ser descartada. $O$ lentinan trata-se de uma $\beta-1,6$ glucana helicoidal, com ramificações $\beta-1,6$ e $\beta-1,3$ piranosídeo, de alto peso molecular, onde apenas existem açúcares na molécula, o que a torna bastante tolerante ao aquecimento, sem a ocorrência de mudanças em sua estrutura (Ikekawa, 1969; Jones; Wasser \& Weiss, 1999).

\subsection{Efeito de diferentes preparações de $L$. edodes na germinação de conídios e formação de apressórios por $E$. turcicum e $C$. sublineolum em lâminas recobertas com poliestireno}

Podemos observar na Tabela 19, que as preparações do cogumelo $L$. edodes inibiram ou reduziram a formação de apressório, apesar da baixa taxa de formação dos mesmos no controle.

Porém é possivel verificar algumas diferenças em relação ao número de conídios germinados, sendo que as maiores reduções foram observadas nos tratamentos filtrado de basidiocarpo, filtrado de basidiocarpo autoclavado, filtrado de píleo e filtrado de estípe. Esses tratamentos também apresentaram um bom controle do crescimento micelial in vitro de E. turcicum, conforme já discutido (Tabelas 1, 2, 3, 4 e 8).

Para o lentinan, não era esperada a observação de efeitos sobre a germinação dos conídios de E. turcicum, pois como citado anteriormente, o lentinan é tido como um ativador do sistema de defesa humano (Kanai et al., 1980; Suzuki et al., 1994). Além disso, na literatura, inexistem citações sobre a ação do lentinan sobre fungos e em especial os fitopatogênicos. 

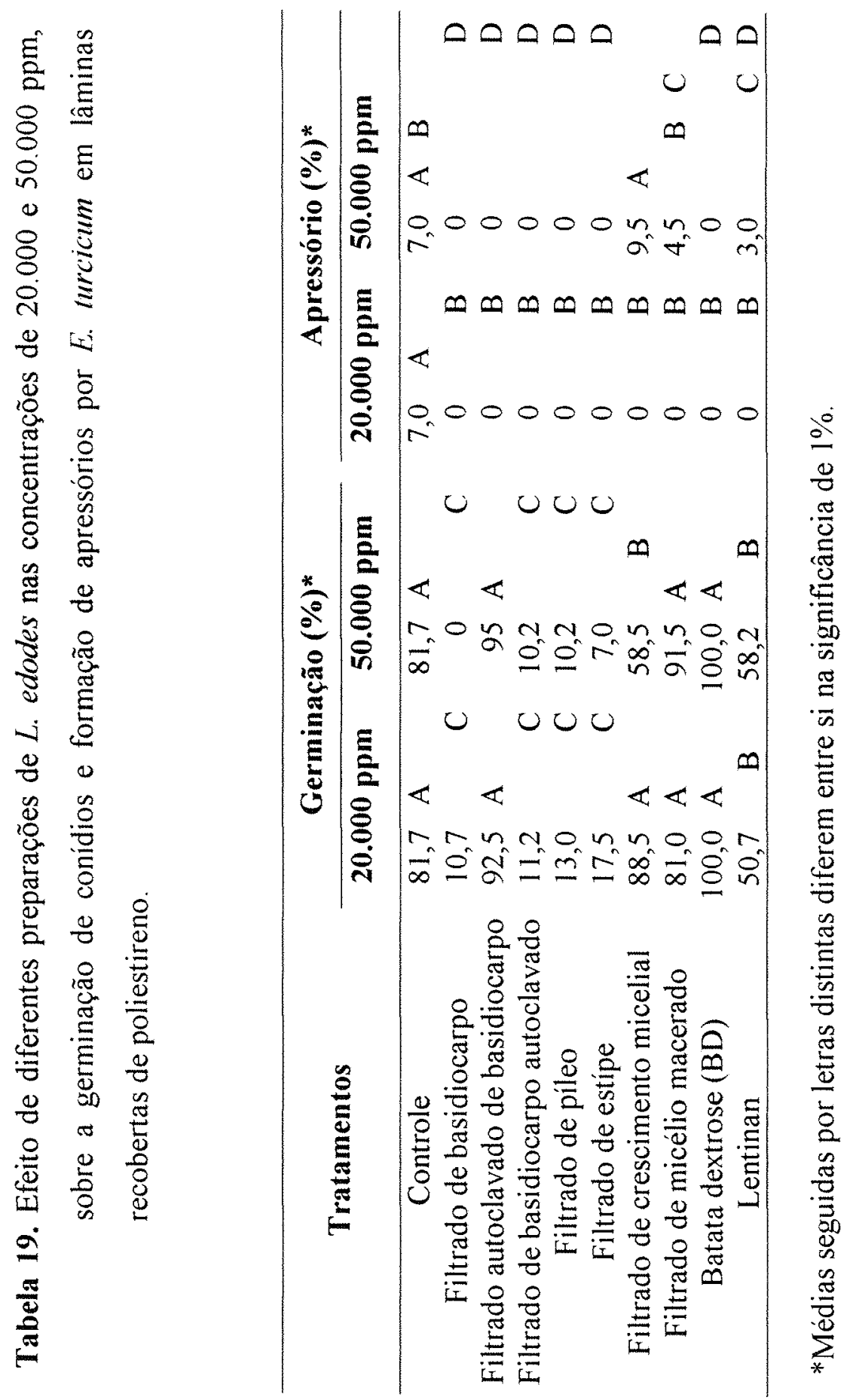
Com respeito ao filtrado de crescimento micelial, esperava-se que o mesmo tivesse algum efeito significativo no controle de E. turcicum, visto que os ensaios visando a redução do crescimento micelial foram bastante expressivos (Tabela 14). No entanto, as atividades de crescimento micelial e germinação de esporos são fatores independentes e portanto passiveis de exibirem essas diferenças.

Pela observação da Tabela 19, temos que o filtrado de crescimento micelial apresentou um pequeno efeito na redução da germinação de conídios de $E$. turcicum, quando do aumento da concentração do filtrado. Esse resultado indica a possibilidade de existir algum componente no filtrado de crescimento micelial capaz de alterar a germinação de esporos, porém o mesmo encontra-se em baixa concentração ou exibir baixa atividade inibitória.

$\mathrm{Na}$ Tabela 20 observa-se que a inibição da germinação de esporos foi total para o filtrado de basidiocarpo, do mesmo modo observado na Tabela 19, além dos tratamentos filtrado de pileo e estípe. Observa-se também na Tabela 20 que os tratamentos filtrado de crescimento micelial e lentinan apresentaram um bom efeito inibidor da germinação de conidios, porém ocasionaram um estímulo da formação de apressórios, limitando assim, o uso destas preparações para o controle de $C$. sublineolum.

A formação de apressórios de C. sublineolum (Tabela 20) foi inibida totalmente com os filtrados de basidiocarpo, filtrado de basidiocarpo autoclavado, filtrado de píleo, filtrado de estipe e filtrado de micélio macerado. No entanto para as preparações de filtrado de basidiocarpo autoclavado e filtrado de micélio macerado observa-se também um estímulo na germinação de esporos (Tabela 20). Porém, apesar destes resultados, é possível o aproveitamento destas preparações no controle de $C$. sublineolum, visto que a germinação de conídios deste patógeno apresenta-se desuniforme, e uma vez os conidios germinados, ocorre uma rápida formação de apressórios, os quais são bastante resistentes a variações do clima e a produtos quimicos como os fungicidas (Nicholson, 1992). 
Tabela 20. Efeito de diferentes preparações de L. edodes à concentração de 20.000 ppm, sobre a germinação de conídios e formação de apressórios por $C$. sublineolum em làminas recobertas de poliestireno.

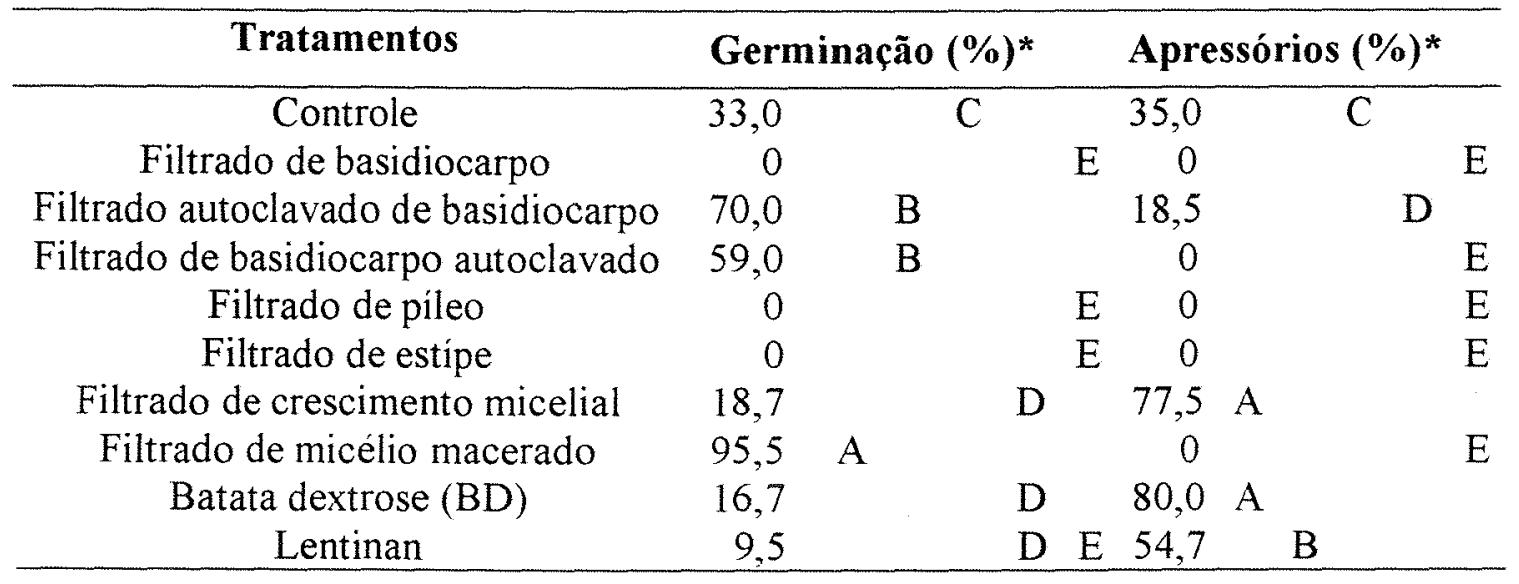

*Médias seguidas por letras distintas diferem entre si na significância de 1\%. 
Deste modo, se fosse encontrada alguma substância capaz de induzir uma germinação uniforme dos conídios, sem a formação de apressórios, teriamos maiores chances no controle do patógeno, e em sua fase mais vulnerável, que corresponde ao crescimento micelial. Assim sendo, o filtrado de basidiocarpo autoclavado e o filtrado de micélio macerado (Tabela 20) poderiam ser produtos potenciais para o estímulo da germinação de conídios de C. sublineolum e seu posterior controle.

\subsection{Dosagens de fitoalexinas em mesocótilos de sorgo e cotilédones de soja}

Na Tabela 21 pode-se observar que o acúmulo de fitoalexinas foi pouco expressivo em relação ao controle positivo, embora os filtrados de basidiocarpo, píleo e estípe terem elicitado uma quantidade razoável de fitoalexinas em relação ao controle (água). Porém, os resultados obtidos com os filtrados de crescimento micelial e micélio macerado ficam sob suspeita, devido ao efeito do meio de cultura batata dextrose (BD). Apesar das sucessivas lavagens em água destilada do micélio, ainda resta a dúvida se o efeito elicitor não foi devido a algum componente remanescente do meio de cultura. $O$ C. sublineolum presente neste ensaio serviu como controle positivo, indicando que o experimento foi conduzido de maneira adequada e as baixas concentrações obtidas não foram devidas a problemas experimentais.

Por sua, vez as dosagens de gliceolina podem ser observadas na Tabela 22 , os diferentes preparados induziram o acúmulo de gliceolina, porém em menor escala quando comparados ao tratamento com $S$. cereviseae, o qual serviu como um controle positivo. Os tratamentos filtrado de basidiocarpo, filtrado autoclavado de basidiocarpo, filtrado de basidiocarpo autoclavado e filtrado de estipe foram os que induziram o maior acúmulo de gliceolina. Porém, para os tratamentos filtrado de crescimento micelial e filtrado de micélio macerado, temos as mesmas dúvidas ocorridas com as fitoalexinas de sorgo, onde podemos ter uma possivel interferência do BD nas preparações. 
Tabela 21. Dosagem de fitoalexinas em mesocótilos de sorgo Brandes após o tratamento com diferentes preparações de $L$. edodes medidos à $480 \mathrm{~nm}$ de absorbância.

\begin{tabular}{|c|c|c|c|}
\hline Tratamentos* & $\begin{array}{l}\mathrm{Abs}_{4} \\
\text { tecid }\end{array}$ & ma de & \\
\hline Controle & 0,7 & & $\mathrm{~B}$ \\
\hline Filtrado de basidiocarpo & 1,1 & A & $\mathrm{B}$ \\
\hline Filtrado autoclavado de basidiocarpo & 0,6 & & B \\
\hline Filtrado de basidiocarpo autoclavado & 0,5 & & $\mathrm{~B}$ \\
\hline Filtrado de píleo & 1,4 & A & $\mathrm{B}$ \\
\hline Filtrado de estípe & 1 & A & $\mathrm{B}$ \\
\hline Filtrado de crescimento micelial & 1,4 & A & B \\
\hline Filtrado de micélio macerado & 2 & A & $\mathrm{B}$ \\
\hline Batata dextrose & 2,7 & A & \\
\hline Lentinan & 0,6 & & $\mathrm{~B}$ \\
\hline
\end{tabular}


Tabela 22. Efeito de diferentes preparações de $L$. edodes no acúmulo de gliceolina em cotilédones de soja var. IAC-8.

\begin{tabular}{cllllll}
\hline Tratamentos* $^{*}$ & \multicolumn{3}{l}{ Gliceolina $\left(\mathbf{A b s}_{\mathbf{2 8 5} \mathbf{~ n m}}\right)^{* *}$} & \\
\hline Controle (água) & 0,27 & & & & D \\
Filtrado de basidiocarpo & 0,99 & A & & & \\
Filtrado autoclavado de basidiocarpo & 0,91 & A & B & & \\
Filtrado de basidiocarpo autoclavado & 0,96 & A & B & & \\
Filtrado de píleo & 0,48 & & & C & D \\
Filtrado de estípe & 0,95 & A & B & & \\
Filtrado de crescimento micelial & 0,67 & A & B & C & \\
Filtrado de micélio macerado & 0,73 & A & B & C & \\
Batata dextrose & 0.98 & A & & & & \\
Lentinan & 0,22 & & & & D \\
\hline
\end{tabular}

${ }^{*}$ Controle positivo representado por Saccharomyces cereviseae, $\operatorname{Abs}_{285 \mathrm{~nm}}=2,07$

**Médias seguidas por letras distintas diferem entre si na significância de $1 \%$ 
Podemos observar que existe alguma correlação entre as Tabelas 21 e 22 , onde os melhores tratamentos elicitores para as fitoalexinas de sorgo e soja foram filtrado de basidiocarpo, filtrado de estipe, filtrado de micélio e filtrado de micélio macerado. Esses resultados eram esperados, visto que em diversos trabalhos são relatados que os componentes da parede fúngica constituem-se em potentes elicitores de mecanismos de defesa em plantas (Leite et al,, 1997).

Com base na informação acima, era esperado que o tratamento com lentinan apresentasse também algum efeito elicitor mais pronunciado no acúmulo de fitoalexinas, visto que o mesmo é um componente da parede celular do cogumelo $L$ edodes (Ikekawa, 1969). Porém, os resultados encontrados não significam que o lentinan não tenha potencial para a indução de proteção, visto que a expressão da resistência é devida à ativação de diversos mecanismos (Pascholati \& Leite, 1994). Nestes ensaios foi avaliado apenas um dos possiveis mecanismos de defesa induzidos, que são as fitoalexinas, restando ainda outros componentes tais como proteínas-RP, quitinase, glucanase, fenil alanina amônia-liase, peroxidases, etc, que inclusive podem atuar de maneira mais eficiente ou mesmo complementando o conjunto de mecanismos de proteção envolvidos durante a patogênese (Aist, 1983; Isaac, 1992; Pascholati \& Leite, 1994).

Finalmente, os resultados obtidos servem como um dado complementar demonstrando que nas preparações de $L$. edodes, existem substàncias elicitoras de fitoalexinas em sorgo e soja.

\subsection{Dosagens de carboidratos, proteínas e $\beta$ 1,3-glucanas}

As dosagens de carboidratos, proteinas e $\beta$ 1,3-glucanas podem ser observadas nas Tabelas 23,24 e 25 , onde foram obtidas dosagens bastante elevadas tanto de proteinas como de carboidratos para quase todas as amostras avaliadas, bem como altas concentrações de $\beta$ 1,3-glucanas em relação ao meio batata dextrose. 
Tabela 23. Conteúdo de carboidratos (açúcares solúveis) em diferentes preparações de $L$. edodes.

\begin{tabular}{|c|c|c|c|c|}
\hline Tratamentos & \multicolumn{4}{|c|}{ mg de glicose $/ \mathbf{m l}^{*}$} \\
\hline Filtrado de basidiocarpo & 2,06 & $\mathrm{C}$ & & \\
\hline Filtrado autoclavado de basidiocarpo & 0,97 & & & $\mathrm{~F}$ \\
\hline Filtrado de basidiocarpo autoclavado & 1,58 & & $\mathrm{E}$ & \\
\hline Filtrado de pileo & 0,82 & & & $\mathrm{~F} \mathrm{C}$ \\
\hline Filtrado de estípe & 0,72 & & & $\mathrm{C}$ \\
\hline Filtrado de crescimento micelial & 12,73 & A & & \\
\hline Filtrado de micélio macerado & 1,75 & & D & \\
\hline Batata dextrose & 2,96 & B & & \\
\hline Lentinan & 0,87 & & & $\mathrm{FC}$ \\
\hline
\end{tabular}

*Médias seguidas por letras distintas diferem entre si na significância de 1\%. 
Tabela 24. Conteúdo de proteínas em diferentes preparações de $L$. edodes.

\begin{tabular}{|c|c|c|c|}
\hline Tratamentos & \multicolumn{3}{|c|}{$\mu \mathrm{g}$ de proteína $/ \mathrm{ml}^{*}$} \\
\hline Filtrado de basidiocarpo & 136,5 & & \\
\hline Filtrado autoclavado de basidiocarpo & 29,0 & $\mathrm{E}$ & \\
\hline Filtrado de basidiocarpo autoclavado & 130,6 & $\mathrm{C}$ & \\
\hline Filtrado de pileo & $152,9 \mathrm{~A}$ & & \\
\hline Filtrado de estipe & 83,8 & $\mathrm{D}$ & \\
\hline Filtrado de crescimento micelial & 2,8 & & $\mathrm{~F}$ \\
\hline Filtrado de micélio macerado & 2,8 & & $\mathrm{~F}$ \\
\hline Batata dextrose & 2,8 & & $F$ \\
\hline Lentinan & 0,4 & & $\mathrm{G}$ \\
\hline
\end{tabular}

* Médias seguidas por letras distintas diferem entre si na significância de $1 \%$. 
Tabela 25. Conteúdo de $\beta$-glucana em diferentes preparações de $L$. edodes.

\begin{tabular}{|c|c|c|c|c|c|}
\hline Tratamentos & \multicolumn{4}{|c|}{ mg $\beta$ glucana/ml* } & \\
\hline Filtrado de basidiocarpo & 7,2 & & & $\mathrm{D}$ & \\
\hline Filtrado autoclavado de basidiocarpo & 7,1 & & & D & \\
\hline Filtrado de basidiocarpo autoclavado & 7,4 & & & $\mathrm{D}$ & \\
\hline Filtrado de píleo & 5,3 & & & & E \\
\hline Filtrado de estípe & 9,8 & & $\mathrm{C}$ & & \\
\hline Filtrado de crescimento micelial & 32,8 & A & & & \\
\hline Filtrado de micélio macerado & 17,1 & B & & & \\
\hline Batata dextrose & 0,0 & & & & $\mathrm{C}$ \\
\hline Lentinan $(1 \mathrm{~g} / \mathrm{ml})$ & 1,25 & & & & $\mathrm{~F}$ \\
\hline
\end{tabular}

*Médias seguidas por letras distintas diferem entre si na significância de $1 \%$. 
Pelos resultados encontrados. torna-se dificil o estabelecimento de uma correlação entre as elicitações de fitoalexinas em sorgo e soja, com as dosagens de carboidratos, proteínas e $\beta$ 1,3-glucanas realizadas. No entanto, se observarmos os menores resultados das Tabela 24 e 25 , poderemos levantar algumas hipóteses. Pela Tabela 24, podemos observar que a quantidade de proteínas presentes no filtrado de crescimento micelial, micélio macerado, $\mathrm{BD}$ e lentinan são muito baixas.

Por sua vez, se considerarmos que os elicitores das fitoalexinas em sorgo e soja são de natureza proteica, os dados disponiveis ficariam ilógicos quando comparássemos com as Tabelas 21 e 22 , pois tanto o $\mathrm{BD}$ como os filtrados de crescimento micelial e o filtrado de micélio macerado, elicitaram as maiores quantidades de fitoalexinas, indicando que provavelmente o elicitor envolvido não seja uma proteína. Além disso, observando-se também a Tabela 25 , eliminamos a possibilidade destes compostos estarem entre as $\beta$ 1,3-glucanas, visto que o $\mathrm{BD}$ não apresentou $\beta$ 1,3glucanas e foi uma das preparações que mais elicitou o acúmulo de fitoalexinas em sorgo e soja.

Dessa maneira, por eliminação restam apenas os carboidratos, embora não possamos afirmar com certeza de que esta seja a natureza do elicitor das fitoalexinas. Devemos, também, levar em consideração que estes são estudos preliminares, sendo necessária a caracterização com maior precisão das moléculas com atividade elicitora. Visto que podemos ter envolvimento não apenas de açúcares, mas também de lipídeos ou ainda açúcares ligados a proteínas.

É importante lembrar que os elicitores atuam de forma especifica, podendo ser reconhecidos ou não pela planta. Assim, a não elicitação de defesa em determinadas plantas não significa obrigatoriamente que o produto utilizado não apresente atividade elicitora, pois dentro de uma mesma espécie podemos ter diferenças quanto à resposta elicitora pelo simples fato da mudança do cultivar utilizado nos ensaios (Pascholati \& Leite, 1984; Leite et al, 1997). 
Leite et al. (1997) citam o fato de glicopeptídeos isolados por fracionamento de componentes da parede celular de leveduras, exibirem a capacidade de elicitar etileno e a atividade da fenil alanina amônia-liase em células de tomate. No entanto, foi demonstrado que este elicitor era dependente de sua fração proteica e, quando separado por hidrólise o mesmo tornava-se inativo como elicitor. A manose resultante do processo de hidrólise, competia de maneira específica pelos sítios de ligação dos receptores na membrana plasmática vegetal, impedindo a elicitação de defesa na planta. Esta é uma possibilidade não descartada para os elicitores obtidos a partir das preparações do shiitake.

\subsection{Uso das diferentes preparações de $L$. edodes no controle de $E$. turcicum e $C$.} sublineolum em sorgo, $X$. campestris pv. passiflora em maracujá e TMV em fumo

Através dos ensaios de laboratório, foi efetuada a seleção prévia das diferentes preparações de $L$. edodes. Com base nos resultados sumarizados na Tabela 26 , foram selecionados os filtrados de basidiocapo para os fitopatógenos fúngicos e TMV, além do filtrado de estípe e filtrado de crescimento micelial para o ensaio com a bactéria. O lentinan também foi selecionado, visto que o mesmo tratar-se de uma uma amostra purificada, de $\beta-1 ; 3$ glucana, obtida da parede celular do cogumelo shiitake (lkekawa, 1969). Além disso, com base em citações da literatura que relatam os componentes da parede celular fúngica como bons elicitores de proteção (Ayers et al., 1976; Isaac, 1992; .Leite et al., 1997) decidiu-se pelo uso da amostra de lentinan nos ensaios com plantas.

Os resultados dos ensaios utilizando os fungos fitopatogènicos (Figura 8) estão nas Tabelas 27 e 28 , onde pode-se observar que o filtrado de basidiocarpo e o lentinan reduziram a severidade das doenças causadas por E. turcicum e C. sublineolum (Tabelas 27 e 28), em plantas de sorgo Brandes e Tx-398B, respectivamente. 


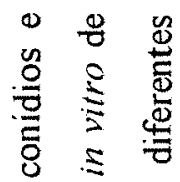

용 :

芯

焉 吾 品

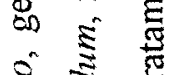

इ

-

유 :

芯

르용

0 응

可 0

惫焉 总

율 융

总 总

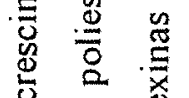

잉

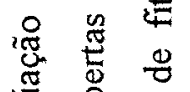

尝 $\frac{8}{8} \frac{0}{0}$

-

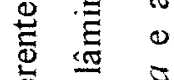

岕 跑

告

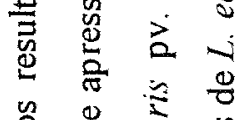

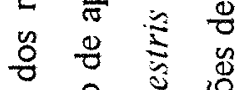

号

요

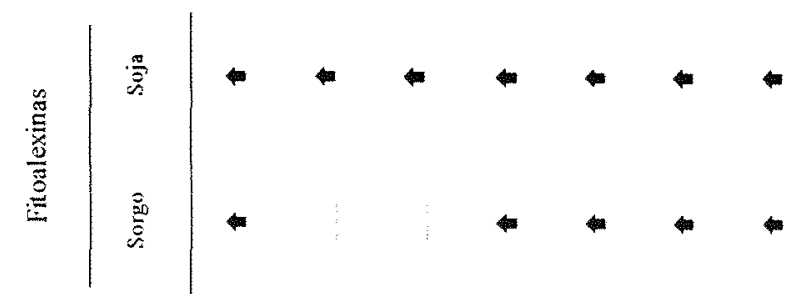

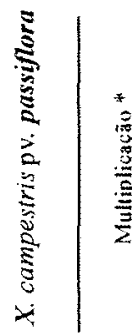

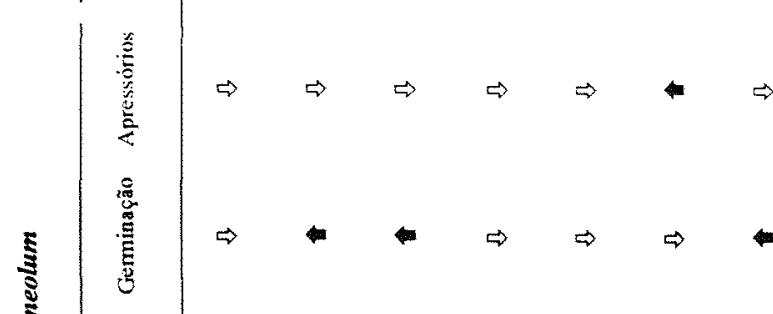

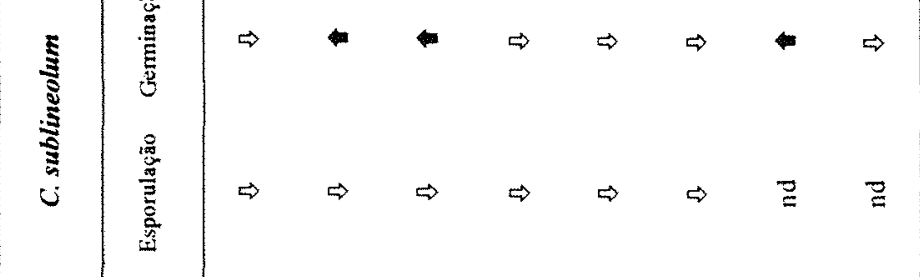

$\frac{\pi}{5}$

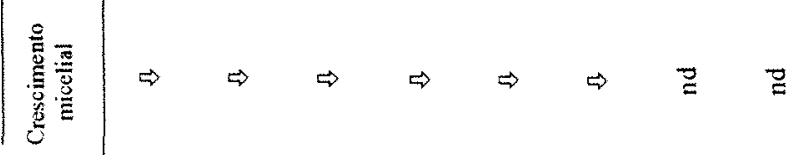

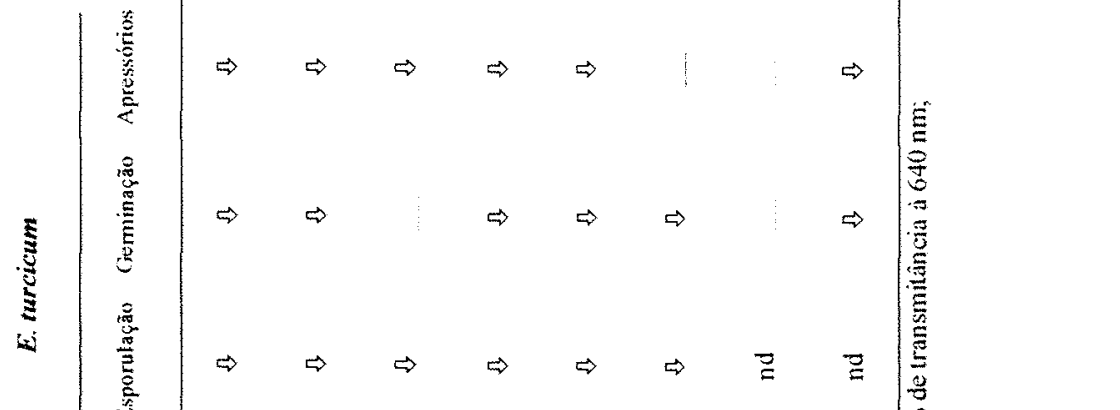


Tabela 27. Efeito de diferentes preparações de L. edodes sobre a severidade de E. turcicum em folhas de sorgo (cv. Brandes)

\begin{tabular}{clc}
\hline Tratamentos $^{* * *}$ & \multicolumn{3}{l}{ severidade média $(\%)^{*}$} \\
\hline Controle (água) & $27,8 \%$ & $\mathrm{~A}$ \\
Lentinan & $20,8 \%$ & $\mathrm{~B}$ \\
Filtrado de basidiocarpo & $18,2 \%$ & $\mathrm{~B}$ \\
\hline
\end{tabular}

*Médias seguidas por letras distintas diferem entre si na significância de $1 \%$.

** Severidade avaliada na $5^{\text {a }}$ folha.

***Preparações aplicadas $48 \mathrm{~h}$ antes da inoculação do patógeno. 
Tabela 28. Efeito de diferentes preparações de $L$. edodes sobre a severidade de C. sublineolum em folhas de sorgo (cv. Tx 398-B).

\begin{tabular}{clc}
\hline Tratamentos & \multicolumn{3}{c}{ severidade média $(\%)^{*}$} \\
\hline Controle (água) & $25,4 \%$ & $\mathrm{~A}$ \\
Lentinan & $10,6 \%$ & $\mathrm{~B}$ \\
Filtrado de basidiocarpo & $7,0 \%$ & $\mathrm{~B}$ \\
\hline
\end{tabular}

* Médias seguidas por letras distintas diferem entre si na significância de 1\%.

** Severidade avaliada na 5 folha.

***Preparações aplicadas $48 \mathrm{~h}$ antes da inoculação do patógeno. 
As amostras de lentinan apesar de não apresentarem nenhum efeito biológico sobre os patógenos em condições de laboratório, ocasionou um controle dos referidos fungos equivalente a um dos filtrados de $L$. edodes. Contrariando inclusive, os resultados obtidos para o acúmulos de fitoalexinas em sorgo e soja (Tabelas 21 e 22), visto não ter induzido o acúmulo dessas substâncias. Porém, em virtude das fitoalexinas não serem os únicos mecanismos envolvidos na proteção durante o processo de elicitação e defesa das plantas (Aist, 1983; Isaac, 1992; Madamanchi \& Kuc; Pascholati $\&$ Leite, 1994) os resultados obtidos são possiveis de serem encontrados.

Deste modo, pode-se sugerir que o modo de ação do lentinan, deve envolver a elicitação de algum outro mecanismo de resistência, visto que o mesmo não apresenta atividade biológica in vitro, além de baixa elicitação de fitoalexinas.

Ayres et al (1976) demonstraram que fragmentos da parede celular de fungos fitopatogênicos são potentes elicitores de defesa de plantas, sendo estes elicitores associados a polissacarídeos do tipo $\beta$ glucana. Em função da natureza do lentinan era esperado que o mesmo tivesse algum efeito protetor sobre as plantas tratadas, visto que o mesmo é uma $\beta$ glucana (Tabela 26) (Ikekawa, 1969).

A pequena diferença numérica entre o tratamento lentinan e filtrado de basidiocarpo pode ser devido a outros mecanismos de ação deste filtrado, como por exemplo a antibiose e substància inibidoras da germinação de esporos e formação de apressórios ou outros elicitores presentes no filtrado.

Para a bactéria $X$. campestris pv. passiflora, podemos observar através da Tabela 29, que o lentinan e os filtrados de estípe e crescimento micelial reduziram o número de infecções locais e sistêmicas (Figura 9).

Embora as preparações filtrado de estípe e lentinan não serem estatísticamente diferentes quanto ao número de infecções locais, existe uma pequena diferença numérica ocorrida entre as amostras, e que pode ser discutida levando-se em consideração o forte efeito inibidor do filtrado de estipe sobre a multiplicação bacteriana, matando-as inclusive, onde para o lentinan isto não ocorre. 
Tabela 29. Efeito de diferentes preparações de L. edodes sobre a incidência média de infecções locais e sistêmicas de $X$. campestris $\mathrm{pv}$. passiflorae em folhas de maracujá amarelo azedo.

\begin{tabular}{|c|c|c|c|c|c|}
\hline \multirow{2}{*}{ Tratamentos } & \multicolumn{5}{|c|}{ Incidência média* } \\
\hline & \multicolumn{2}{|c|}{ Infeccões locais } & \multicolumn{3}{|c|}{ Infeccões sistêmicas } \\
\hline Controle (água) ${ }^{* *}$ & 55,6 & $\mathrm{~A}$ & 4,1 & A & \\
\hline Filtrado de crescimento micelial & 19,5 & B & 2,0 & & B \\
\hline Lentinan & 16,8 & B & 2,0 & & B \\
\hline Filtrado de estípe & 13,4 & B & 0,6 & & $\mathrm{C}$ \\
\hline
\end{tabular}

* Médias seguidas por letras distintas diferem entre si na significância de $1 \%$. **Preparações aplicadas $48 \mathrm{~h}$ antes da inoculação do patógeno. 
Por outro lado, visto que o lentinan não exerceu nenhum efeito inibitório sobre a multiplicação da bactéria in vitro (Tabela 18 ), a redução nos sintomas da doença indicam a possivel ocorrência da indução de proteção, a qual foi demonstrada por Piccinin (1995) no mesmo patossistema, utilizando-se de suspensões de células de $S$. cereviseae.

Com relação aos resultados obtidos para o filtrado de crescimento micelial, os mesmos encontram-se dentro do esperado, visto que esta preparação atua diretamente sobre a bactéria, inibindo seu crescimento (Tabela 17), assim como o filtrado de estípe (Tabela 12).

Porém o filtrado de estípe apresentou um controle e estatisticamente melhor, que o filtrado de crescimento micelial, além de ter menor número de lesões locais que os demais tratamentos. Essas diferenças apesar de pequenas para preparações com efeito biológico semelhante, podem ser devido à elicitação de proteção ou ainda a problemas de estabilidade das moléculas das diferentes preparações.

Para os ensaios com vírus, podemos observar através da Tabela 30 , que a aplicação dos preparados inibiu o surgimento de lesões locais em fumo cv. TNN (Figura 10), sendo provável a existência de algum efeito indutor das preparações utilizadas. A não observação de proteção das plantas com relação às infecções sistêmicas do TMV (Figura 10), tanto em 15 ou 30 dias após as inoculações, poderia ser explicado pelo fato da utilização de 2 diferentes cultivares de fumo. Os elicitores poderiam ser reconhecidos e ativarem os mecanismos de defesa latentes para o $\mathrm{cv}$. TNN, e para o cv. Turkish, este reconhecimento pode nem sequer ter ocorrido (Pascholati \& Leite, 1984; Leite et al, 1997).

Uma segunda hipótese seria a de que a elicitação dos mecanismos de defesa apesar de ocorrerem em ambas as cultivares, apresenta-se ineficiente ou lenta para o fumo Turkish, onde apesar dos mecanismos de proteção estarem presentes e serem ativados, o patógeno colonizaria mais rapidamente os tecidos do hospedeiro que a velocidade de resposta dos mecanismos de defesa da planta (Marley \& Hillochs, 1993). 
Tabela 30. Efeito de diferentes preparações de $L$. edodes sobre a incidência média de lesões locais em fumo TNN e sistêmicas em fumo Turkish, avaliadas aos 15 e 30 dias após a inoculação com TMV.

\begin{tabular}{|c|c|c|c|c|c|c|}
\hline \multirow{2}{*}{ Tratamentos } & \multirow{2}{*}{\multicolumn{2}{|c|}{ Lesões locais* }} & \multicolumn{4}{|c|}{ Infecções sistêmicas* } \\
\hline & & & $15 \mathrm{di}$ & & 30d & \\
\hline Controle (água)** & 334,0 & A & 0,5 & A & 0,53 & A \\
\hline Lentinan & 158,6 & B & 0,42 & A & 0,42 & A \\
\hline Filtrado de basidiocarpo & 103,8 & & 0,40 & A & 0,41 & A \\
\hline
\end{tabular}

*Médias seguidas por letras distintas diferem entre si na significância de $1 \%$. **Preparações aplicadas $48 \mathrm{~h}$ antes da inoculação do patógeno. 
O fumo cv. Turkish pode também apresentar uma baixa resposta à elicitação de seus mecanismos de proteção, quando comparado ao fumo cv. TNN. Esta hipótese é reforçada pelo fato do fumo cv. TNN não apresentar infecção de vírus TMV de forma sistêmica, devido a reação de hipersensibilidade conferida pelos de genes $\mathrm{NN}$, (Tokeshi \& Salgado, 1980). E levando-se em consideração que a indução de proteção somente é possivel caso exista um minimo de resistência a ser induzida, essa diferença de proteção entre os diferentes cultivares de fumo, poderia ser explicada, devido à baixa resistência elicitada em fumo cv. Turkish. Onde apesar dos mecanismos latentes de proteção serem induzidos eficientemente, a expressão da resistência seria insuficiente para conter a infecção e colonização do virus do TMV. (Hammerschmidt and Kuc, 1995 e Saindrenan \& Guest, 1995). Com base nos resultados observados na Tabela 30, temos que as diferentes preparações do shiitake, reduziram o número de lesões infecções locais do virus $\mathrm{TMV}$, no fumo $\mathrm{cv}$. TNN, porém qual seria o modo de ação destas preparações ?. Um dos possiveis mecanismos envolvidos, seria a indução de proteção, pela elicitação de inibidores de protease (Mitra, 1995; Bel \& Linthorst, 1995). Outra hipótese seria pela ação de PR-proteínas (Mitra, 1995). No entanto ainda são hipóteses, e que devem ser comprovadas em estudos posteriores e complementares a este.

\subsection{Comentário final}

Pelos resultados obtidos podemos observar que um dos principais efeitos in vitro das preparações do cogumelo shiitake, foi sobre a redução ou inibição da esporulação dos fungos E. turcicum e C. graminicola (Tabela 26), e efeitos inibitórios sobre germinação e formação de apressórios. 
As diferentes preparações também apresentaram um bom efeito no controle da bactéria $X$. campestris pv. passiflora (Tabela 26). As preparações do shiitake que apresentaram um bom efeito inibitório in vitro, também mostraram-se eficientes quando aplicadas em plantas, no controle de fitopatógenos fúngicos, bacterianos e virais (Tabelas 27, 28, 29 e 30). Sendo o provável modo de ação no controle dos fitopatógenos, devido à antibiose e/ou à indução de proteção. O que torna as preparações de filtrado de basidiocarpo, filtrado de estipe, filtrado de crescimento micelial e lentinan potenciais elicitores de proteção em plantas.

Com base nos resultados obtidos, sugere-se a condução de ensaios visando a obtenção de outros filtrados a partir de $L$. edodes, porém com solventes orgânicos por exemplo, além de ensaios com outros isolados do cogumelo shiitake. Assim como o estudo de outros cogumelos, visto que existem muitos outros cogumelos comestíveis ou não, e que podem apresentar bons resultados, entre os quais: Oudemanciella canari, Pholiota nameko, Pleurotus spp., Flammulina velutipes, Ganoderma lucidum, Coprinus spp., Grifola frondosa, Agaricus blazei, Suilus (Boletus) edodes, e muitos outros. 


\section{CONCLUSÕES}

Os filtrados de basidiocarpo, píleo, estípe e do crescimento micelial do cogumelo $L$. edodes apresentam substâncias com atividade antibiótica in vitro para os fitopatógenos fúngicos E. turcicum, C. sublineolum e para a bactéria $X$. campestris pv. passiflora.

A natureza inibitória dos compostos encontrados nos filtrados de $L$. edodes são do tipo fúngistática, bacteriostática e bactericida, sendo que todos os filtrados com atividade antimicrobiana mostraram-se termolábeis

Os filtrados de basidiocarpo, píleo, estípe, filtrado autoclavado de basidiocarpo, filtrado de badiocarpo autoclavado, filtrado de crescimento micelial e filtrado de micélio macerado elicitaram a produção de fitoalexinas do complexo das deoxiantocianidinas em sorgo e gliceolinas em soja.

O lentinan, apesar de não exibir efeito antibiótico in vitro e nem mesmo elicitar fitoalexinas em sorgo e em soja, apresentou juntamente com o filtrado de basidiocarpo redução da severidade dos sintomas causados por E. turcicum e $C$. sublineolum em sorgo, diminuição da incidência de infecções locais e sistêmicas de $X$. campestris pv. passiflora em maracujá, bem como a redução da incidência de lesões locais em fumo $\mathrm{cv}$. TNN, porem não foram eficientes no controle de infecções sistêmicas em fumo cv. Turkish. 
Os filtrados de crescimento micelial e estipe de $L$. edodes foram efetivos na redução da incidência de infecções locais e sistêmicas de $X$ campestris pv. passiflora em maracujá.

Finalmente, o filtrado de estípe mostrou-se superior ao filtrado de píleo no controle in vitro do crescimento micelial e da esporulação de E. turcicum e $C$. graminicola, bem como da multiplicação de $X$. campestris pv. passiflora.

Com base nestas conclusões, evidencia-se o uso potêncial do shiitake no controle de doenças de plantas. 
Anexo 


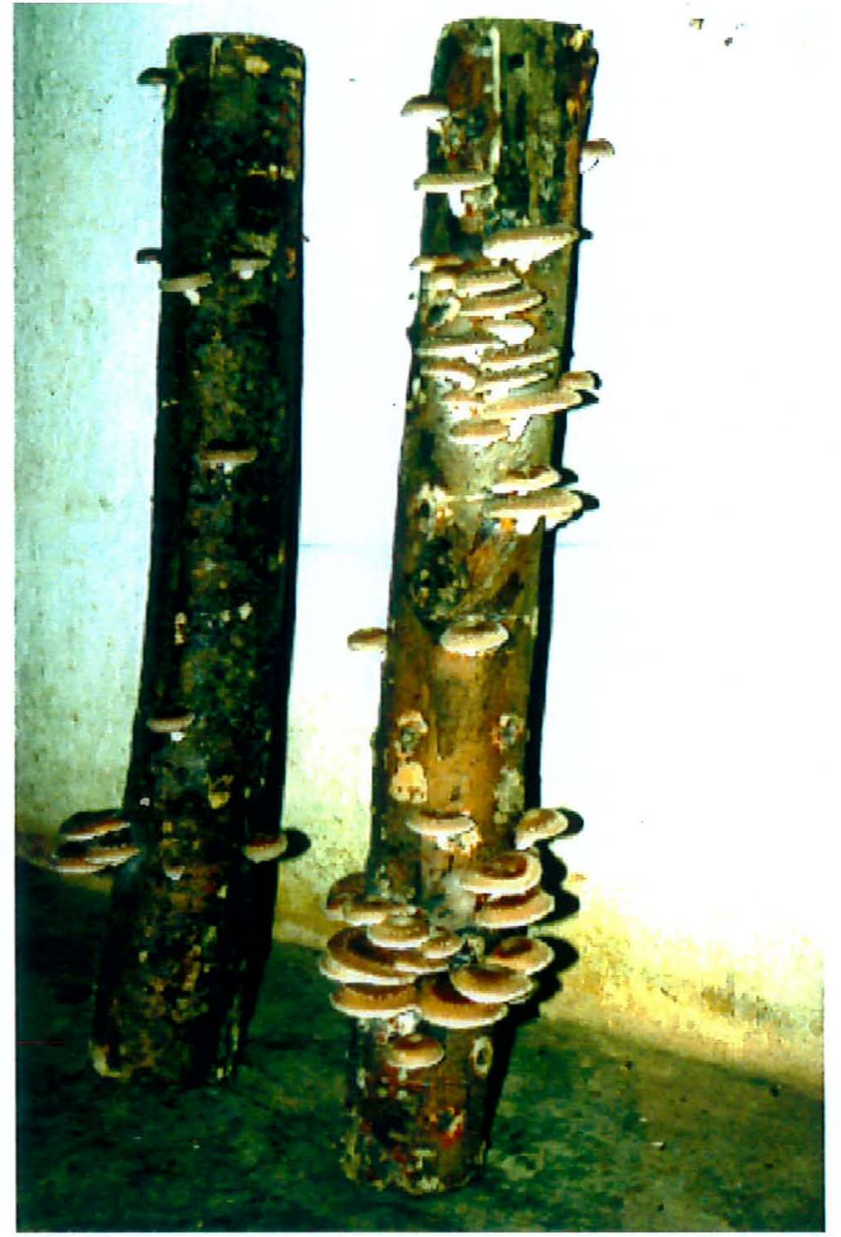

Figura 1. Basidiocapos do cogumelo comestível Lentinula edodes (shiitake) em toras de eucalipto. 


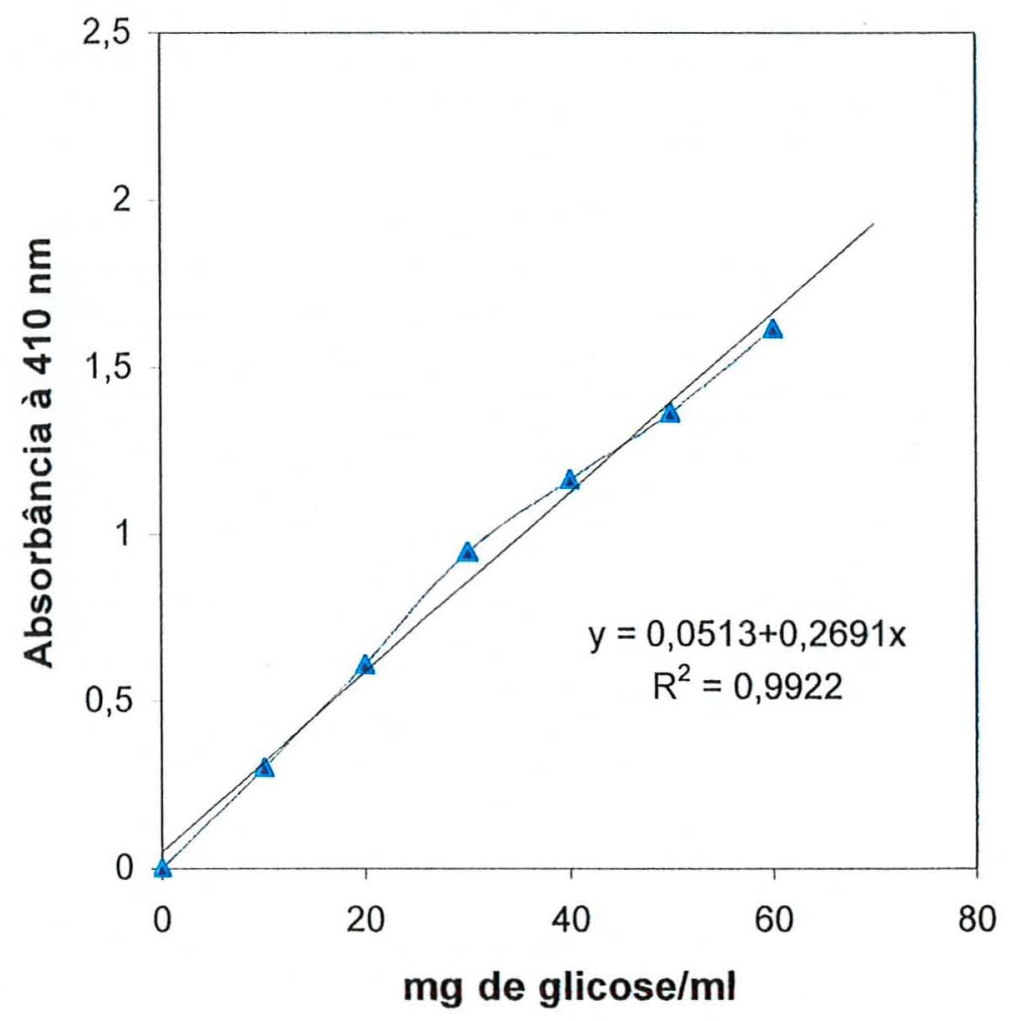

Figura 2. Curva padrão para a determinação do teor de açúcares totais pelo método de Lever. 


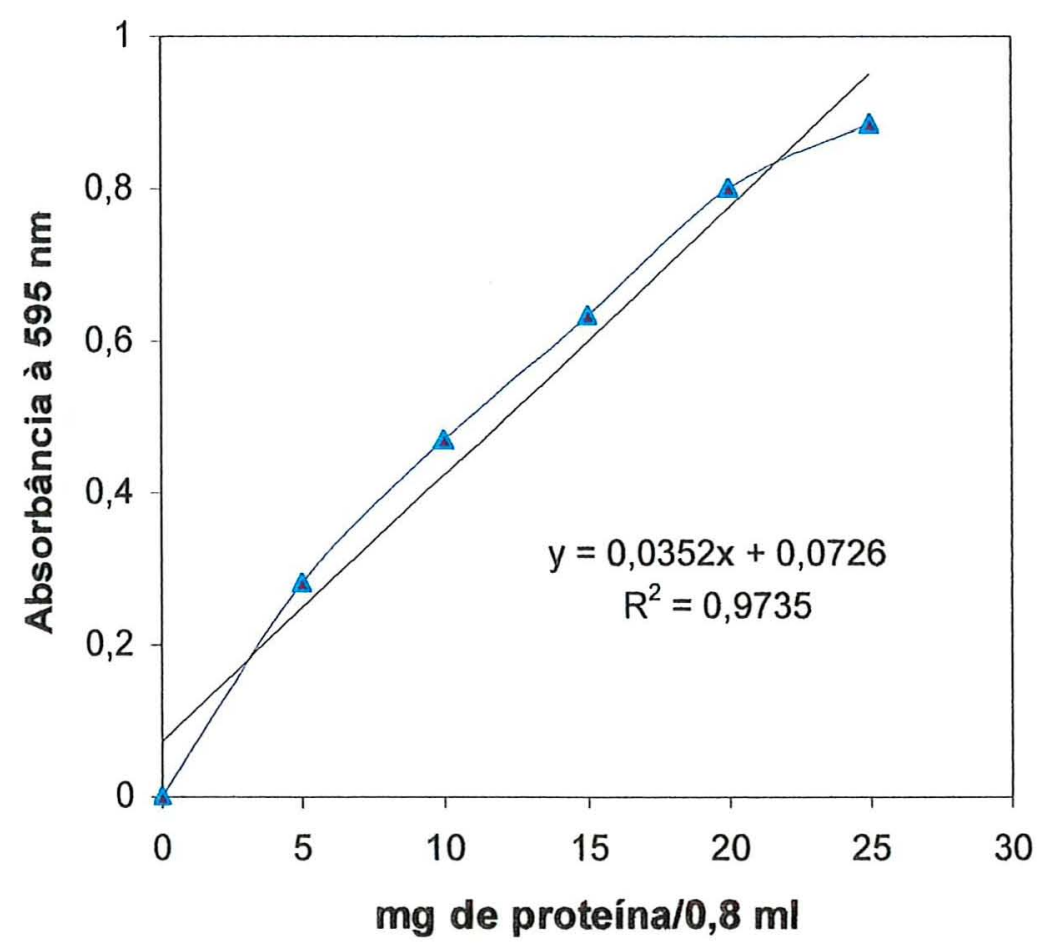

Figura 3. Curva padrão para a dosagem de proteínas pelo método de Bradford. 


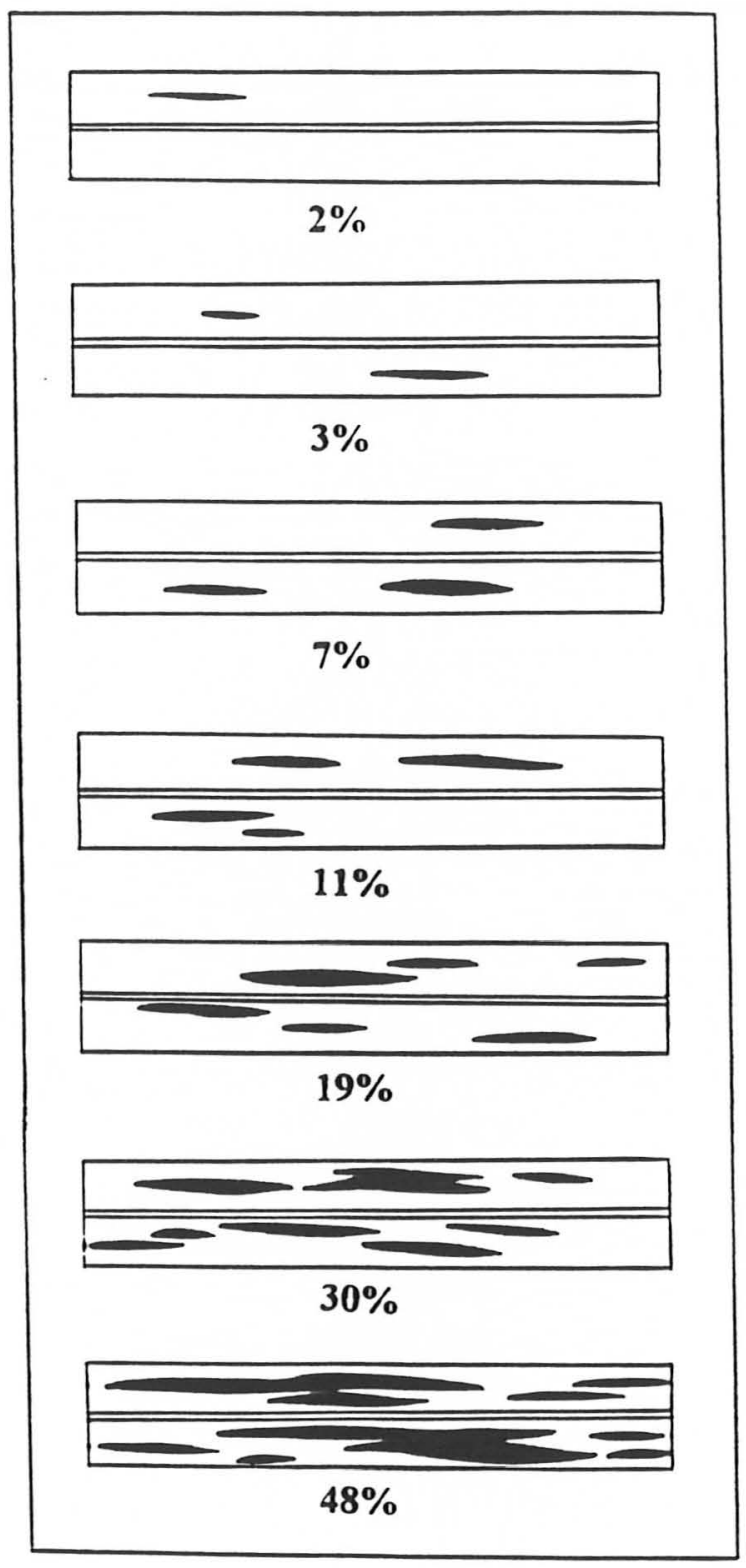

Figura 4. Escala diagramática para a avaliação da severidade de E. turcicum em folhas de sorgo. 

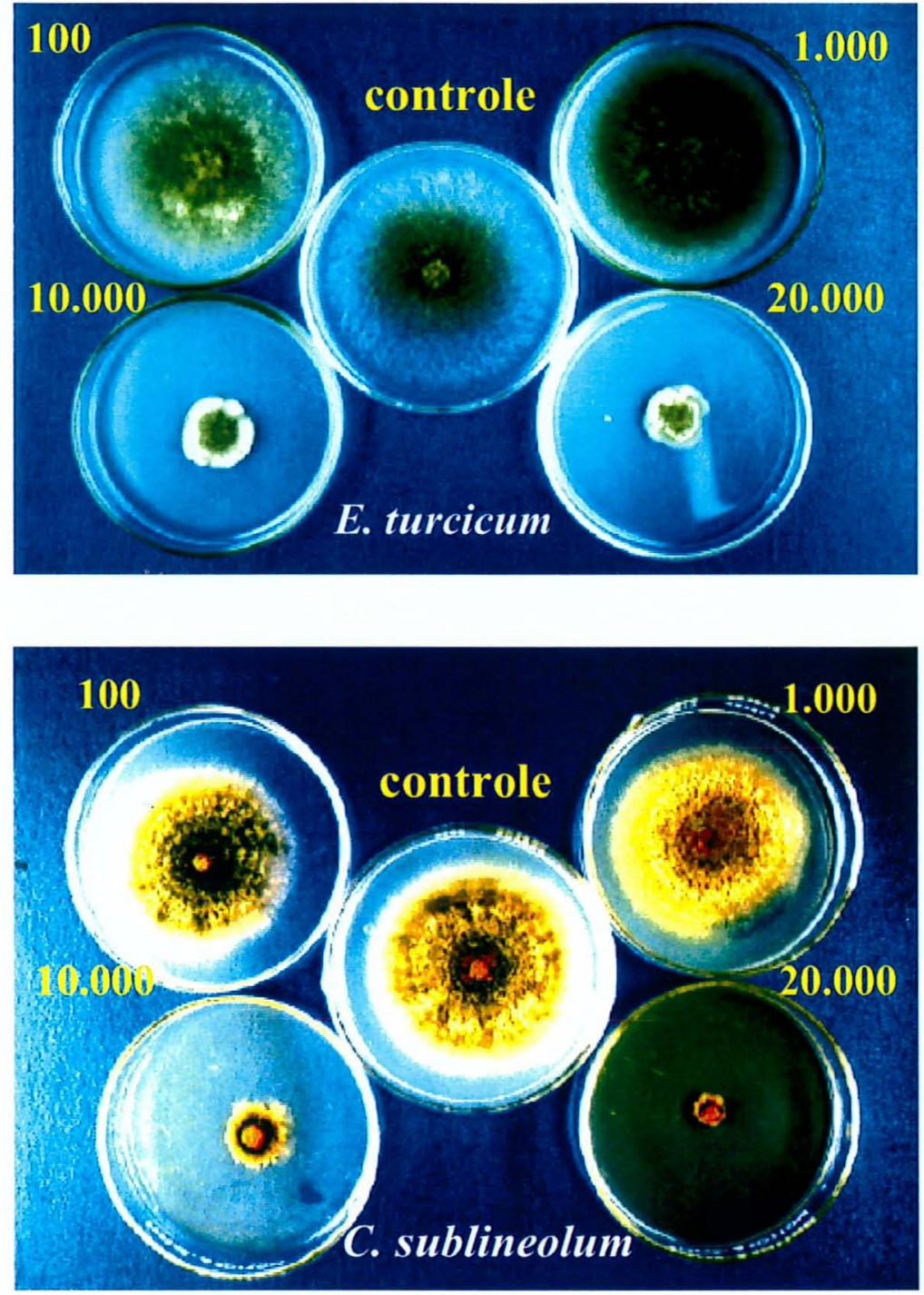

Figura 5. Efeito do filtrado de basidiocarpo seco, em diferentes concentrações, sobre o crescimento micelial de $E$. turcicum e C. sublineolum. 

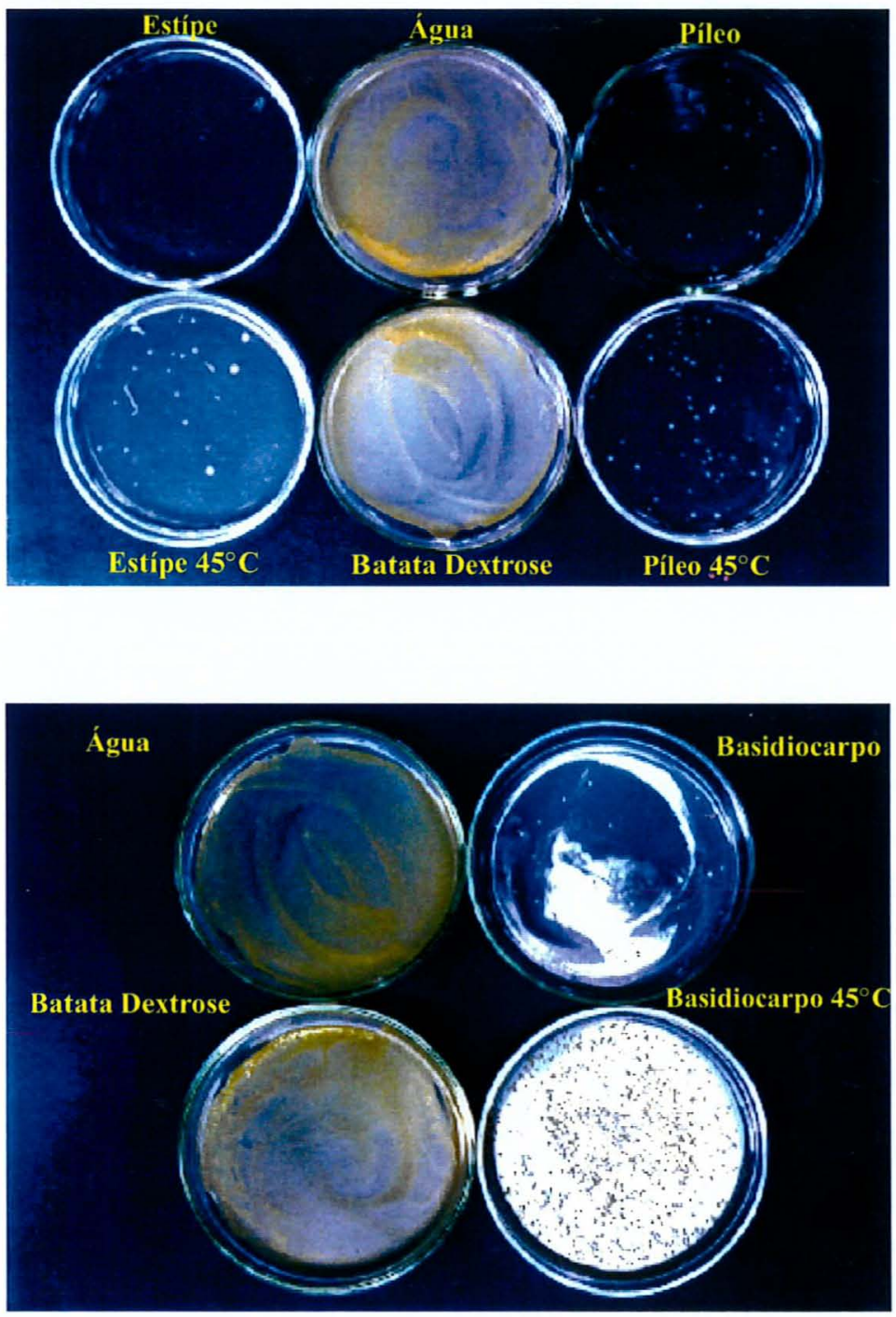

Figura 6. Efeito dos filtrado de basidiocarpo, píleo e estípe secos, na concentração de 20.000 ppm, incorporados em água, com ou sem aquecimento à $45^{\circ} \mathrm{C}$, sobre o crescimento de $X$. campestris pv. passiflora. 

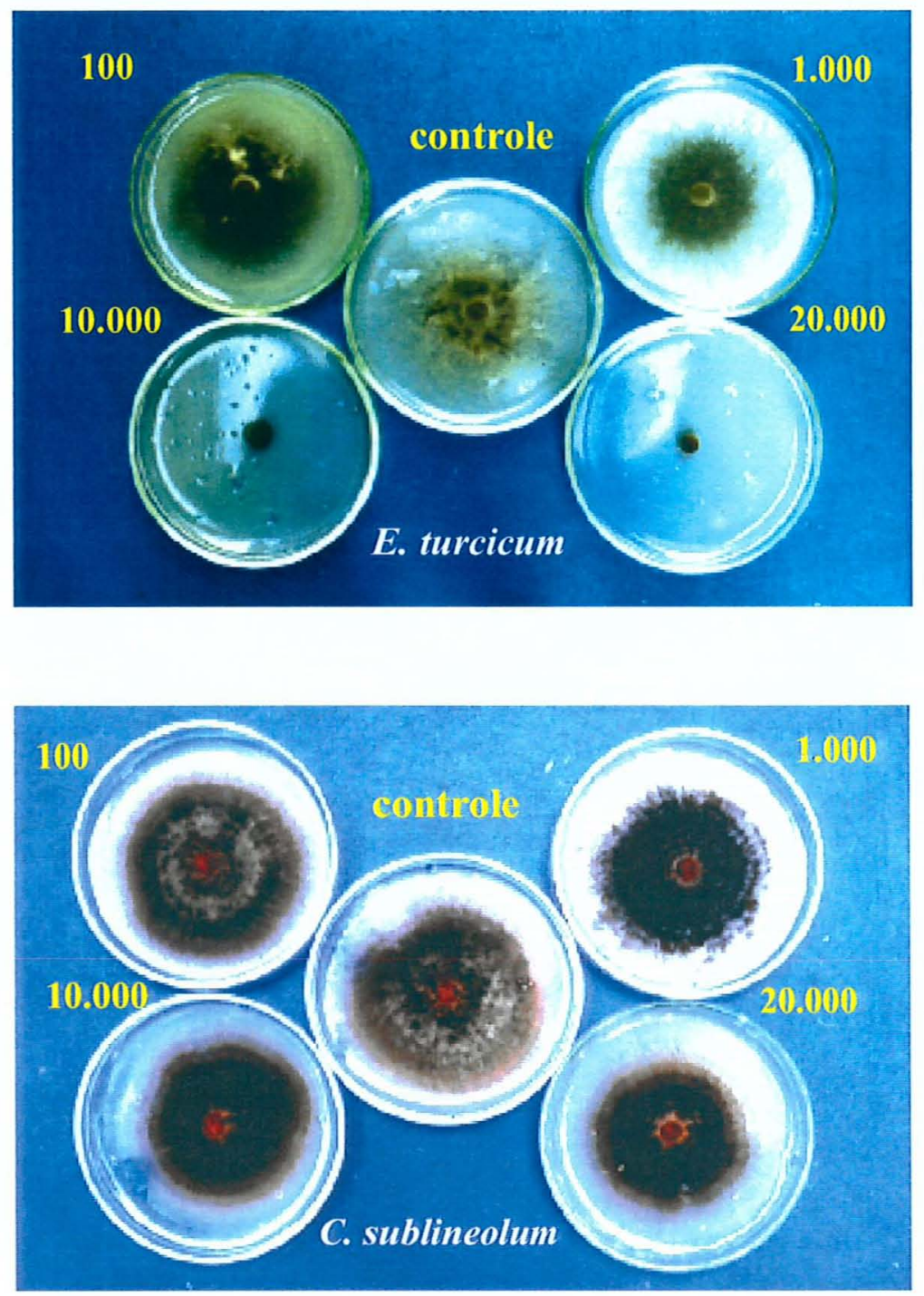

Figura 7. Efeito do filtrado de crescimento micelial de $L$. edodes em diferentes concentrações, sobre o crescimento micelial de E. turcicum e $C$. sublineolum. 

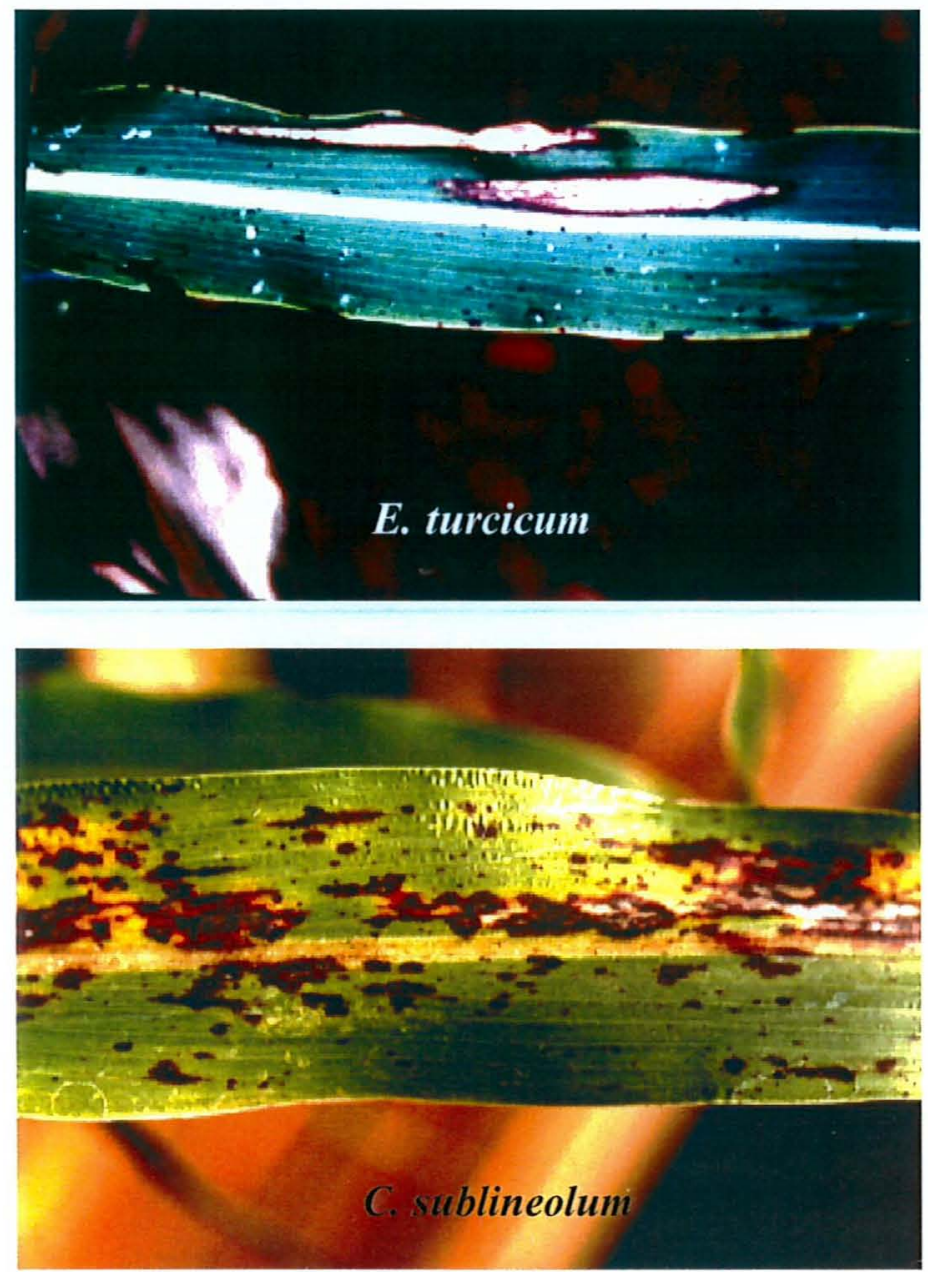

Figura 8. Sintomas de E. turcicum (queima das folhas) e C. sublineolum (antracnose) em folhas de sorgo cvs. Brandes e Tx-398B, respectivamente. 

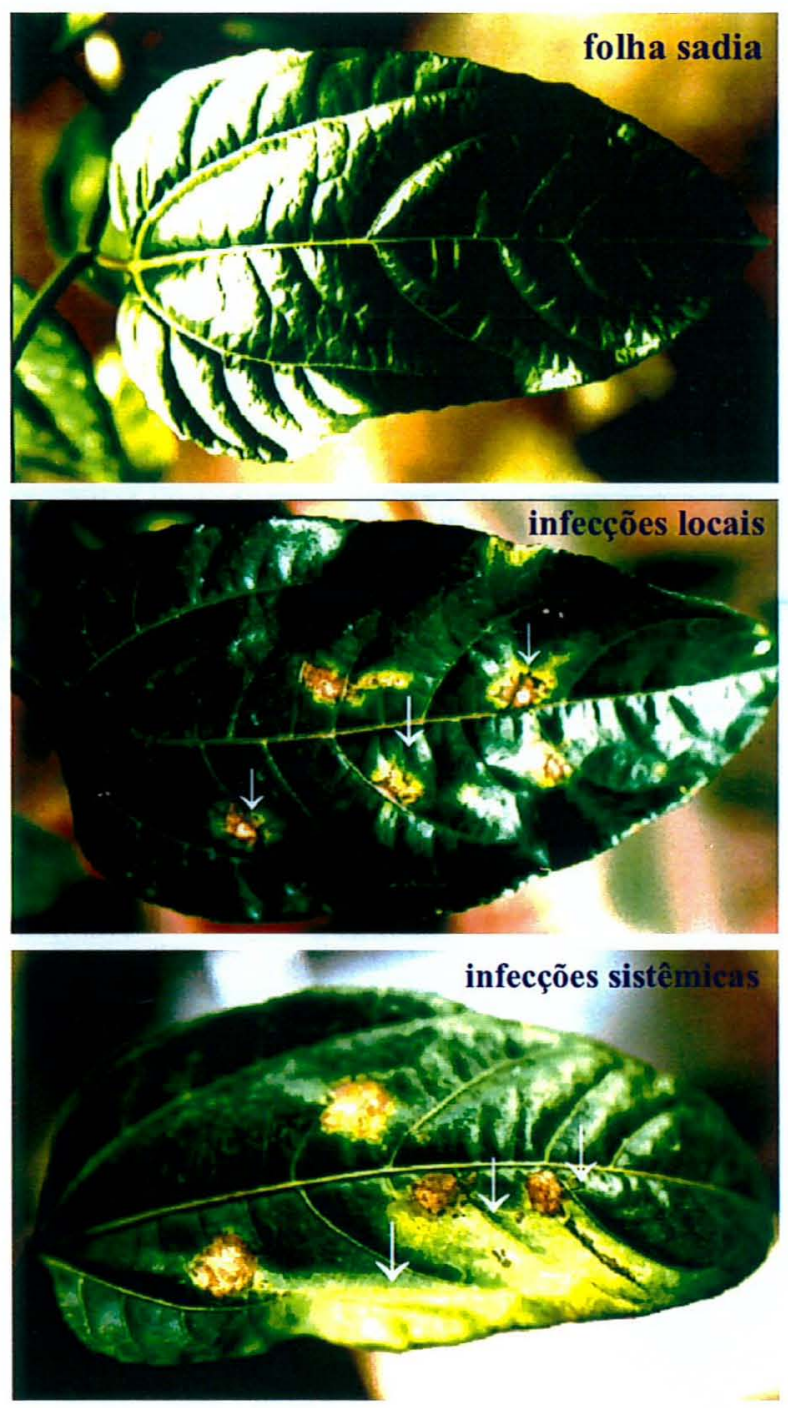

Figura 9. Sintomas de infecções locais e sistêmicas de $X$. campestris pv. passiflora (mancha oleosa do maracujazeiro), em folhas de maracujá azedo amarelo. 

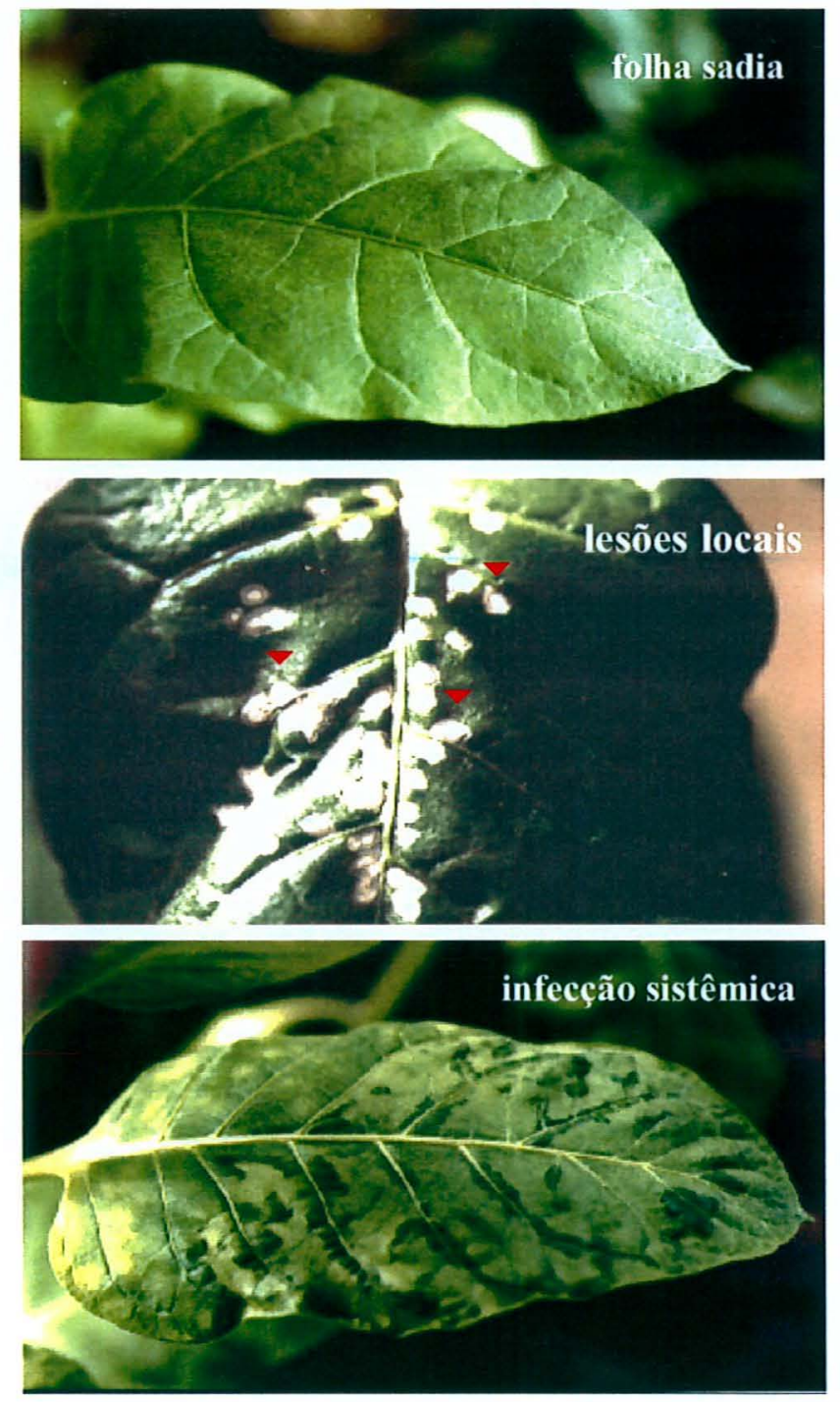

Figura 10. Sintomas de lesões locais e infecções sistêmicas do vírus do mosaico do fumo em folhas de fumo cvs. TNN e Turkish. 


\section{REFERÊNCIAS BIBLIOGRÁFICAS}

AIST, J.R. Structural responses as resistance mechanisms. In: BAYLEY, J.A.; DEVERAL, B.J. (Ed.) The Dynamics of Host Defense. Sydney: Academic Press, 1983. p.33-70.

ALCORN, J.L. The taxonomy of "Helminthosporium" species. Annual Review of Phytopathology, v.26, p.37-56, 1988.

ALI, M.E.K. Physiological races of Colletotrichum graminicola on sorghum. Plant Disease, v.71, n.5, p.402-404, 1987.

ALI, M.E.K.; WARREN, H.L. Relationship between anthracnose leaf bligth and losses in grain yield of sorghum. Plant Disease, v.71, n.9, p.803-806, 1987.

AMORIM, L. Avaliação de doenças. In: BERGAMIN FILHO, A.; KIMATI, H.; AMORIM, L. (Ed.) Manual de Fitopatologia. 3.ed. São Paulo: Editora Agronômica Ceres Ltda, 1995. v.1. cap.32, p.674-671.

AYRES, A.R.; EBEL, J.; VALENT, B.S.; ALBERSHEIM, P. Host-pathogen interactions: fractionation and biological activity of an elicitor isolated from the mycelial walls of Phytophthora megasperma var. sojae. Plant Physiology, v.57, p. $760-765,1976$. 
BACH, E.E. Distinção morfológica e isoenzimática de Bipolaris spp. e Dreschelera tritici-repentis do trigo; aspectos bioquímicos das interações e indução de resistência. Piracicaba, 1997. 150p. Tese (Doutorado) - Escola Superior de Agricultura "Luiz de Queiroz", Universidade de São Paulo.

BAILlIEUl, F.; GENETET, I.; KOOP, M.; SAINDRENAN, P.; FRITIG, B.; KAUFFMANN, S. A new elicitor of the hypersensitive response in tobacco: A fungal glycoprotein elicits cell death, expression of defense genes, production of salicylic acid, and induction of systemic acquired resistance. The Plant Journal, v. 8, n. 4, p. $551-560,1995$.

BAKER, R. Diversity in biological control. Crop Protection, v.10, p.85-94, 1994.

BALASS, M.; LEVY, Y. Antagonistic relationships between Helminthosporium maydis and Exserohilum turcicum in corn plants and in artificial media. Canadian Journal of Plant Pathology, v.6, p.313-3176, 1984.

BALMER, E. Doenças do milho. In: GALLI, F.; CARVALHO, P.C.T.; TOKESHI, H. et al. (Ed.) Manual de Fitopatologia - Doenças das Plantas Cultivadas. São Paulo: Editora Agronòmica Ceres Ltda, 1980. v.2. cap.27, p.371-391.

BARBOSA, L.S. Resistência de Passiflora sp. a Xanthomonas campestris pv. e detecção do patógeno em sementes. Viçosa, 1995. 66p. Dissertação (M.S.) Universidade Federal de Viçosa.

BASSE.C.W.; BOLLER, T. Glycopeptide elicitors stress responses in tomato cells. $N$ Linked glycans are essential for activity but act as supressors of the same activity when released from the glycopeptides. Plant Physiology, v.98, n.4, p. 1239-1247, 1992. 
BELL, A. A. Biochemical mechanisms of disease resistance. Annual Review of Plant Physiology, v. 32, p.21-81, 1981.

BENHAMOU, N.; BÉLANGER, R.R. Benzothiadiazole - mediated induced resistance to Fusarium oxysporum f.sp. radicis-lycopersici in tomato. Plant Physiology, v. 118, p.1203-1212, 1998.

BENHAMOU, N.; KLOEPPER, J.W; TUZUN, S. Induction of resistance against Fusarium wild of tomato by combination of chitosan with an endophytic bacterial strain: ultrastructure and cytochemistry of the host response. Planta, v.204, p.153$168,1998$.

BENHAMOU, N.; LAFONTAINE, P.J.; NICOLE, M. Induction of systemic resistance to Fusarium crown and root rot in tomato plants by seed treatment with chitosan. Phytopathology, v.84, n.12, p.1432-1444, 1994.

BERNARD, N. L'evolution dans la symbiose, des orchideés et leurs champignons commensaux. Annales dans Sciences Naturales, v.9, p.1-196, 1909.

BHATTACHARYYA, A.; ROY, A.K. Induction of resistance in rice plant against sheath blight with non-conventional chemicals. Indian Phytopathology, v. 51, p.8186,1998 .

BIANCO-COLLETO, M.A. Basidiomiceti in relazione all'antibiosi note II. Ativitá antibiotica dei miceli e dei liquidi di coltura. Giornale di Bactteriologia Virologia e Immunologia, v. 75, p. 267-274, 1981.

BLAKEMAN, J.P.; FOKKEMA, N.J. Potential for biological control of plant diseases on the phylloplane. Annual Review of Phytopathology, v.20, p. 167-192, 1982. 
BLEICHER, J.; BALMER, E.; ZINSLY, J.R. Resistência horizontal a Exserohilum turcicum em milho, cultivar pirapoca amarela. Fitopatologia Brasileira, v.18, p.187-193, 1993.

BOL, J.F.; LINTHORST, H.J.M. Putative role of pathogenesis-related proteins in the antiviral responses of plants. In: CHESSIN, M.; DeBORDE, D.; ZIPF, A. (Ed.) Antiviral proteins in higher plants. Boca Raton: CRC Press Inc, 1995. cap. 9, p. $147-160$.

BOLAND, G.L. Biological control of plant diseases with fungal antagonists: challenges and opportunities. Canadian Journal of Plant Pathology, v. 12, p.295-299, 1990.

BOLLER, T. Hydrolytic enzymes in plant disease resistance. In: KOSUGE, T.; NESTER, E.W. (Ed.) Plant-Microbe Interactions, Molecular and Genetic Perspectives. New York: MacMillan, 1987. v.2. p.385-413.

BRADFORD, M.M. A rapid and sensitive method for the quantification of microgram quanties of protein utilizing the principles of protein-dye binding. Analytical Biochemistry, v. 72, p. 248-254, 1976.

BREENE, W.M. Nutritional and medicinal value of specialty mushrooms. Journal of Food Protection, v.53, n.10, p.883-894, 1990.

BROWN, N.A. Experiments with Paris daisy and rose to produce resistance to crown gall. Phytopathology, v.13, p.87-89, 1923.

CAMARGO, L.E.A.; BERGAMIN FILHO, A. Controle genético. In: BERGAMIN FILHO, A.; KIMATI, H.; AMORIM, L. (Ed.) Manual de Fitopatologia. 3.ed. São Paulo: Editora Agronômica Ceres Ltda, 1995. v.1. cap.37, p.729-760. 
CAMPBELL, R. Biological control of soil borne diseases: some present problems and different approaches. Crop Protection, v.13, n.1, p.4-13, 1994.

CARDWELL, K.F. Pathotypes of Colletotrichum graminicola and seed transmission of sorghum anthracnose. Plant Disease, v.73, n.3, p.255-257, 1989.

CARROL, R.B.; LUKEZIC, F.L. Induced resistance in alfafa to Corynebacterium insidiosum by prior treatment with avirulent cells. Phytopathology, v.62, p.555-563, 1972.

CARUSO, F.; KUC, J. Protection of watermelon and muskmelon against Colletotrichum lagenarium. Physiological and Plant Pathology, v.14, p.191-201, 1979.

CASELA, C.R.; FERREIRA, A.S. Proposta de um sistema de classificação de raças de Colletotrichum graminicola, agente casual de antracnose em sorgo (Sorghum bicolor). Fitopatologia Brasileira, v.12, n.4, p.337-344, 1987a.

CASELA, C.R.; FERREIRA, A.S. Reação de genótipos de sorgo a sete patótipos de Colletotrichum graminicola, agente casual de antracnose. Fitopatologia Brasileira, v. 12, n. 1, p. $60-62,1987 \mathrm{~b}$.

CASELA, C.R.; FERREIRA, A.S. Identificação de fontes de resistència a Colletotrichum graminicola, agente casual de antracnose em sorgo. Fitopatologia Brasileira, v. 13, n.4, p.351-353, 1988a.

CASELA, C.R.; FERREIRA, A.S. Resistència de cultivares de sorgo a Colletotrichum graminicola, agente casual de antracnose. Fitopatologia Brasileira, v.13, n.1, p.7$10,1988 \mathrm{~b}$. 
CASELA, C.R.; FREDERIKSEN, R.A. Evidence for dilatory resistance to anthracnose in sorghum. Plant Disease, v.77, n.9, p.908-911, 1993a.

CASELA, C.R.; FREDERIKSEN, R.A. Survival of Colletotrichum graminicola sclerotia in sorghum stalk residues. Plant Disease, v.77, n.8, p.825-827, 1993 b.

CASELA, C.R.; FREDERIKSEN, R.A. Pathogenic variability in monoconidial isolates of the sorghum anthracnose fungus Collethotrichum graminicola, from single lesions and from monoconidial cultures. Fitopatologia Brasileira, v.19, n.2, p.149-153, 1994.

CHANG, S.T. Mushrooms and food. BioScience, v.30, p.399-401, 1980.

CHANG, S.T.; MILES, P.G. A new look at cultivated mushrooms. BioScience, v.34, n.6, p.358-362, 1984.

CHAUDHARY, K.C.B.; MATHUR, S.B. Infection of sorghum seeds by Colletotrichum graminicola. Survey, location in seed and transmission of the pathogen. Seed Science \& Technology, v.7, p. 87-92, 1979.

CHET, I. Trichoderma - application, mode of action, and potential as a biocontrol agent of soil-borne plant pathogenic fungi. In: CHET, I. (Ed.) Innovative Approaches to Plant Disease Control. New York: John Wiley and Sons, 1987. p.137-160.

CHET, I.; ORDENLICH, A.; SHAPIRA, R.; OPPENHEIM, A. Mechanisms of biocontrol of soil borne plant pathogens by rhizobacteria. Plant Soil, v.129, p.85-92, 1990. 
CHIBATA, L; OKUMURA, K.; TAKEYAMA, S.; KOTERA, K. Lentinacin: a new hypocholesterolemic substance in Lentinus edodes. Specialia Experentia, v.25, p. $1237-1238,1969$.

CHIHARA, G.; MAEDA, Y.; HAMURO, J.; SASAKI, T.; FUKUOKA, W. Inhibition of mouse sarcoma 180 by polysaccharides from Lentimus edodes (Berk) Singer. Nature, v.222, n.194, p.687-688, 1969.

COCHRAM, K.W. Medical effects. In: CHANG, S.T.; HAYES, W.A. The Biology and cultivation of edible mushrooms. New York: Academic Press, 1978. p.169187.

COELHO, A.M. A cultura do sorgo no norte de Minas: resultados experimentais. Belo Horizonte: EPAMIG, 1983. 48p. (Série 2).

COOK, R.J.; BAKER, K.F. The Nature and Practice of Biological Control of Plant Pathogens. Saint Paul: The American Phytopathological Society, 1983. 539p.

COOK, D.W.M.; LONG, P.G.; GANESH, S. The combined effect of delayed application of yeast biocontrol agents and fruit curing for the inhibition of the postharvest pathogen Botrytis cinerea in kiwifruit. Postharvest Biology and Technology, v.16, p.233-243, 1999.

CRISAN, E.V.; SANDS, A. Nutritional value. In: CHANG, S.T.; HAYES, W.A. The Biology and cultivation of edible mushrooms. New York: Academic Press, 1978. p.137-168.

DANN, E.K.; DEVERALL, B.J. Effectiveness of systemic resistance in bean against foliar and soilborne pathogens as induced by biological and chemical means. Plant Pathology, v.44, p.458-466, 1995. 
DEAN, R.A.; KUC, J. Induced systemic protection in cucumber: effects of inoculum density and symptom development caused by Colletotrichum lagenarium in previously infected and uninfected plants. Phytopathology, v.76, n.2, p.186-189, $1986 \mathrm{a}$.

DEAN, R.A.; KUC J. Induced systemic protection in cucumbers: the source of the "signal". Physiological and Molecular Plant Pathology, v.28, p.227-233, 1986b.

DIETRICH，R.A.; DELANEY, T.P.; UKNES, S.J.; WARD, E.J.; RYALS, J.A.; DANGL, J.L. Arabidopsis mutants simulating disease resistance response. Cell, v.77, p. 567-577, 1994.

DUIJFF, B.J.; MEIJER, J.W.; BAKKER, P.A.H.M.; SCHIPPERS, B. Siderophoremediated competition for iron and induced resistance in the suppression of Fusarium wilt of carnation by fluorescent Pseudomonas spp. Netherland Journal of Plant Pathology, v.99, p. 277-289, 1993.

DUKE, N.; RAMIREZ, A.V.; TOMIYAMA, K. Systemic induction of resistance in potato plants against Phytophthora infestans by local treatment with hyphal wall components of the fungus. Journal of Phytopathology, v.119, p.232-239, 1987.

DUNLEAVY, J. Control of damping-off of sugar beet by Bacillus subtilis. Phytopathology, v.45, p.252-258, 1955.

ELAD, Y.; CHET, I.; HENIS, Y. Degradation of plant pathogenic fungi by Trichoderma harziamum. Canadian Journal of Microbiology, v.28, p.719-725, 1982. 
ELAD, Y.; KÖHL, J.; FOKKEMA, N.J. Control of infection and sporulation of Botrytis cinerea on bean and tomato by saprophytic bacteria and fungi. European Journal of Plant Pathology, v. 100, p.315-336, 1994a.

ELAD, Y.; KÖHL, J.; FOKKEMA, N.J. Control of infection and sporulation of Botrytis cinerea on bean and tomato by saprophytic yeasts. Phytopathology, v.84, n.10, p.1193-1200, 1994b.

ELLISTON, J.; KUC, J.; WILLIAMS, E.; RAHE, J. Relation of phytoalexin accumulation to local and systemic protection of bean against anthracnose. Phytopathologische Zeitschrift, v.88, p.114-130, 1977.

ESTEVES, A. Incidência de doenças sob condições de campo, em cultivares de milho (Zea mays), em Dourados. Fitopatologia Brasileira, v.9, p.155-160, 1984.

FERNANDES, F.T.; SCHAFFERT, R.E. Anthracnose of sorghum in Brazil. In: INTERNATIONAL WORKSHOP ON SORGHUM DISEASE, Hyderabad, 1978. Proceedings Andhra Pradesh. Hyderabad: ICRISAT, 1978. p.295-296.

FERNÁNDEZ, E.; HERNÁNDEZ, S.; SOLÓRZANO, E.; FERNÁNDEZ, A.; LORENZO, M. Concentraciones de $\mathrm{NaH}_{2} \mathrm{PO}_{4}$ en la induccion de resistencia en tomate frente al hongo Alternaria solani. Revista de Proteccióne Vegetal, v. 18, n.2, p. $113-115,1996$.

FERrEIRA, A.S. A Cultura do Sorgo. Campinas: CATI, 1984. 16p. (Boletim Técnico, $\mathrm{n}^{\circ} 187$ )

FERREIRA, A.S.; CASELA, C.R. Raças patogènicas de Colletotrichum graminicola, agente causal de antracnose em sorgo (Sorghum bicolor). Fitopatologia Brasileira, v. 11, n. 3, p. 84-87, 1986. 
FERREIRA, A.S.; WARREN, H.L. Resistance of sorghum to Colletotrichum graminicola. Plant Disease, v.66. n.9, p.773-775, 1982.

FORCELINI, C.A. Fungicidas inibidores da síntese de esteróis. I-Triazóles. In: LUZ, W.C.; FERNANDES, J.M.C.; PRESTES, A.M.; PICININI, E.C. (Ed) Revisão Anual de Patologia de Plantas. Passo Fundo: Revisão Anual de Patologia de Plantas, 1994. v.2. p. 335-355.

FOUGHT, L.; KUC, J.A. Lack of specificity in plant extracts and chemicals as inducers of systemic resistance in cucumber plants to anthracnose. Journal of Phytopathology, v.144, p.1-6, 1996.

FRANCISCO NETO, E; NAKAMURA, K.; OLIVEIRA, J.C. Influência de alguns fatores na germinação de conídios, no crescimento micelial e na esporulação de alguns isolados de Colletotrichum gloeosporioides, obtidos de Passiflora. Summa Phytopathologica, v.20, n.2, p.96-100, 1994.

FRAVEL, D.R. Role of antibiosis in the biocontrol of plant diseases. Annual Review of Phytopathology, v.26, p.75-91, 1988.

FREDERIKSEN, R.A. Compendium of Sorghum Disease. 2ed. Saint Paul: The American Phytopathological Society, 1991. 82p.

FREITAS, J.C.; ZARAMELA, G.S.; PASCHOLATI, S.F. Efeito de agentes bióticos e abióticos no acúmulo de um complexo de pigmentos e fitoalexinas em mesocótilos de sorgo. Fitopatologia Brasileira, v.18, n.349, 1993. (Resumo) 
FUJII, T.; MAEDA, H.; SUZUKI, F.; ISHIDA, N. Isolation and characterization of a new anti-tumor polysaccharide, KS-2, extracted from culture mycelia of Lentimus edodes. Jounal of antibiotics, v. 31, p. 1079-1090, 1978.

FUCHS, J.G.; MOËNNE-LOCCOZ, Y.; DÉFARO, G. Nonpathogenic Fusarium oxysporum strain Fo47 induces resistance to fusarium wilt in tomato. Plant Disease, v.81, n.5, p.492-496, 1997.

GODOY, C.V.; SALGADO, C.L. Doenças do fumo (Nicotiana tabacum L.). In: KIMATI, H.; AMORIM, L.; BERGAMIN FILHO, A.; CAMARGO, L.E.A.; REZENDE, J.A.M. (Ed.) Manual de Fitopatologia. São Paulo: Editora Agronômica Ceres Ltda, 1997. v.2. p.411-420.

GREENBERG, J.T.; GUO, A.; KLESSIG, D.F.; AUSUBEL, F.M. Programmed cell death in plants: a pathogen-triggered response activated coordinately with multiple defense reactions. Cell, v.77, p.551-563, 1994.

GUEDES, M.E.; RICHMOND, S.; KUC, J. Induced systemic resistance to anthracnose in cucumber as influenced by the location of the inducer inoculated with Colletotrichum lagenarium and onset of flowering and fruiting. Physiological and Molecular Plant Pathology, v.17, p.229-233, 1980.

GUZZO, S.D.; MARTINS, E.M.F. Local and systemic induction of $\beta-1,3$ glucanase and chitinase in coffee leaves protected against Hemileia vastatrix by Bacillus thuringiensis. Journal of Phytopathology, v. 144, p.449-454, 1996.

HADWIGER, L.A.; OGAWA, T.; KUYAMA, H. Chitosan polymer sizes effective in inducing phytoalexin accumulation and fungal suppression are verified with synthesized oligomers. Molecular Plant Microbe Interactions, v. 7, n.4, p.531-533, 1994. 
HADWIGER, L.A.; CHIANG, C.; VICTORY, S.; HOROVITZ, D. The molecular biology of chitosan in plant-pathogen interactions and its application to agriculture. In: SKJÂK, G.; ANTHONSEN, B.; SANDFORD, P. (Ed.) Chitin and chitosan: sources, chemistry, biochemistry, physical properties and applications. Amsterdam: Elsever Applied Sciences, 1988. p.119-138.

HAMMERSCHMIDT, R.; KUC, J. Induced resistance to disease in plants. Dordrecht: Kluwer Academic Publishers, 1995. 182p.

HIJWEGEN, T.; VERHAAR, M.A. Effects to cucumber genotype on the induction of resistance to powdery mildew, Sphaerotheca fuliginea, by 2,6 dichloroisonicotinic acid. Plant Pathology, v.44, p.756-762, 1994.

HIRASAWA, M.; SHOUJ, N.; NETA, T.; FUKUSHIMA, K.; TAKADA, K. Three kinds of antibacterial substances from Lentinus edodes (Berk.) Sing. (Shiitake, an edible mushroom). International Journal of Antimicrobial Agents, v.11, p.151157, 1999.

HOBBS, C. Medicinal mushrooms : an exploration of the tradition, healing and culture. 3.ed. Louveland: Interweare Press, 1996. 251p.

HOFFLAND, E.; HAKULINEN, J.; VAN PELT, J.A. Comparison of systemic resistance induced by avirulent and nonpathogenic Pseudomonas species. Phytopathology, v.86, n. 7, p.757-762, 1996.

HOOS, G.; BLAICH, R. Influence of resveratrol on germination of conidia and mycelial growth of Botrytis cinerea and Phomopsis viticola. Journal of Phytopathology, v.129, p.102-110, 1990. 
IKEKAWA, T.; UEHARA, N.; MAEDA, Y.; NAKANISHI, M.; FUKUOKA, F. Antitumor activity of aqueous extracts of edible mushrooms. Canadian Research, v.29, p.734-735, 1969.

IRINODA, K.; MASIHI, K.N.; CHIHARA, G.; KANEKO, Y.; KATORI, T. Stimulation of microbicidal host defense mechanisms against aerosol influenza virus infection by Lentinan. International Journal of Immunopharmacology, v. 14, n.6, p. $971-977,1992$.

ISAAC, S. Fungal plant interactions. London: Chapman \& Hall, 1992. 418p.

ISHIKAWA, N.K. Avaliação da atividade antagonista de Lentimula edodes. Viçosa, 1997. 114p. Dissertação (M.S.) - Universidade Federal de Viçosa.

ITO, T. Cultivation of Lentimus edodes. In: CHANG, S.T.; HAYES, W.A. The Biology and Cultivation of Edible Mushrooms. London: Academic Press, 1978. p. $461-473$.

JEANDET, P.; BESSIS, R.; SBAGHI, M.; MEUNIER, P. Production of the phytoalexin resveratrol by grapes as a response to Botrytis attack under natural conditions. Journal of Phytopathology, v. 143, p.135-139, 1995.

JENNS, A.E.; KUC, J. Graft transmission of systemic resistance of cucumber to anthracnose induced by Colletotrichum lagenarium and tobacco necrosis virus. Phytopathology, v.69, p.753-756, 1979.

JONES, K. Shiitake: The healing mushroom. Rochester: Healing Arts Press, 1995. $120 \mathrm{p}$. 
JONG, S.C.; BIRMINGHAM, J.M. Medicinal and therapeutic value of the shiitake mushroom. In: NEIDLEMAN, S.; LASKIN, A.I. Advances in Applied Microbiology. London: Academic Press, 1993. v.39 p.153-184.

KANAI, K.; KONDO, E.; JACQUES, P.J. Immunopotentiating effect of fungal glucans as revealed by frequency limitation of post chemotherapy relapse in experimental mouse tuberculosis. Japanese Journal of Medicin Science Biology, v.33, p.283293,1980

KANEDA, T.; TOKUDA, S. Effect of various mushrooms preparation on cholesterol levels in rats. The Journal of Nutrition, v.90, p.371-376, 1966.

KAREL, L.; ROACH, E.S. A Dictionary of Antibiotics. New York: Columbia University Press, 1951. 253p.

KATARIA, H.R.; WILMSMEIER, B.; BUCHENAUER, H. Efficacy of resistance inducers, free-radical scavengers and an antagonistic strain of Pseudomonas fluorecens for control of Rhizoctonia solani AG-4 in bean and cucumber. Plant Pathology, v.46, p.897-909, 1997.

KERR, A. Biological control of crown gall through production of agrocin 84. Plant Disease, v.64, p.25-30, 1980.

KIMATI, $H$. Controle químico. In: BERGAMIN FILHO, A.; KIMATI, H.; AMORIM, L. (Ed.) Manual de Fitopatologia. 3.ed. São Paulo: Editora Agronômica Ceres Ltda, 1995. v.1. cap.38, p.761-785.

KLEMENT, Z.; GOODMAN, R.N. The hypersensitive reaction to infection by bacterial plant pathogens. Annual Review of Phytopathology, v.5, p. 17-44, 1968. 
KLESSING, D.F. Salicylic acid active oxygen species and systemic acquired resistance in plants. Trends in Cell Biology, v.4, p.334-338, 1994.

KLOEPPER, J.W. Host specificity in microbe-microbe interactions: Biological control agents vary in specificity for hosts, pathogen control, ecological habitat, and environmental conditions. BioScience, v.46, n. 6, p.406-409, 1996.

KLOEPPER, J.W.; TUZUNS, S.; ZEHNDER, G.W.; WEI, G. Multiple disease protection by rhizobacteria that induce systemic resistance - historical precedence. Phytopathology, v.87, n.2, p.136-137, 1997.

KOBAYASHI, N.; HIRAMATSU, A.; AKASUKA, T. Purification and chemical properties of an inhibitor of plant virus infection from fruiting bodies of Lentinus edodes. Agriculture and Biological Chemistry, v.51, n.3, p.883-890, 1987.

KOMEMUSHI, S.; YAMAMOTO, Y; FUJTA, T. Purification and identification of antimicrobial substances produced by Lentinus edodes. Journal of Antibacterial and Antifungal Agents, v.24, n.1, p.21-25, 1996.

KRISHNAMURTHY, K.; GNANAMANICKAM, S.S. Biological control of sheath blight of rice: induction of systemic resistance in rice by plant-associated Pseudomonas spp. Current Science, v.72, n.5, p.331-334, 1997.

KUC, J. Induced systemic resistance to plant disease and phytointerferons - Are they compatible?. Fitopatologia Brasileira, v. 10, p.17-40, 1985.

KUC, J.; RICHMOND, S. Aspects of the protection of cucumber against Colletotrichum lagenarium by Colletotrichum lagenarium. Phytopathology, v.67, p.533-536, 1977. 
KUC, J.; RUSH, C. Phytoalexins. Archives of Biochemistry and Biophysics, v.26, n.2, p.455-472, 1985.

LAMPORT, D.T.A. Roles for peroxidases in cell wall genesis. In: GRIPPEN, H; PANEL, C.; GASPAR, T. (Ed) Molecular and Physiological Aspects of Plant Peroxidases. Genova: University of Genova Press, 1986. p.199-207.

LASCA, C.C.; VECCHIATO, M.H.; VALARINI, P.J. Deteç̧ão e identificação de fungos em sementes de sorgo (Sorghım sp.) produzidas no estado de São Paulo. Arquivos do Instituto Biológico de São Paulo, v.53, n. 1/4, p.47-54, 1986.

LEEMAN, M.; DEN OUDEN, F.M.; VAN PELT, J.A.; CORNELISSEN, C.; MATAMALA-GARROS, A. Suppression of fusarium wilt of radish by coinoculation of fluorescent Pseudomonas spp. and root-colonizing fungi. European Journal of Plant Pathology, v. 102, p. 21-31, 1996a.

LEEMAN, M.; DEN OUDEN, F.M.; VAN PELT, J.A.; DIRKX, F.P.M.; STEIJL, H.; BAKKER, P.A.H.M; SCHIPPERS, B. Iron availability affects induction of systemic resistance to fusarium wilt of radish by Pseudomonas fluorecens. Phytopathology, v. 86, n.2, p. $149-155,1996$ b.

LEITE, B.; PASCHOLATI, S.F. Hospedeiro: alterações fisiológicas induzidas por fitopatógenos. In: BERGAMIN FILHO, A.; KIMATI, H; AMORIM, L. (Ed.) Manual de Fitopatologia. 3.ed. São Paulo: Editora Agronômica Ceres Ltda, 1995. v.1. cap. 21, p. 393-416. 
LEITE, B.; RONCATO, L.D.; PASCHOLATI, S.F.; LAMBAIS, M.R. Reconhecimento e transdução de sinais moleculares em interações planta-fungos patogênicos. In: LUZ, C.W.; FERNANDES, J.M.C.; PRESTES, A.M.; PICININI, E.C. (Ed.) Revisão Anual de Patologia de Plantas. Passo Fundo: Revisão Anual de Patologia de Plantas, 1997. p.235-280.

LEITE, B.; SANDER, P.C.; SUGUI, J.A. O papel de compostos voláteis na germinação de esporos fúngicos e na expressão de doenças em plantas. Summa Phytopathologica, v.21, n.2, p.109-116, 1995.

LEONARD, K.J.; THOMPSON, D.L. Effects of temperature and host maturity on lesion development of Colletotrichum graminicola on corn. Phytopathology, v.66, p.635-639, 1976.

LEONG, J. Siderophores: their biochemistry and possible role in the biocontrol of plant pathogens. Annual Review Phytopathology, v.24, p.187-209, 1986.

LEUBA, J.L.; STOSSEL, P. Chitosan and other polyamines: Antifungal activity and interaction with biological membranes. In: MUZZARELLI, R.; JEAUNIAUX, C; GOODAY, G.W. (Ed.) Chitin in Nature and Technology. New York: Plenum Press, 1986. p.215-222.

LEVER, M. A new reaction for colorimetric determination of carbohydrates. Analytical Biochemistry, v.47, p. 273-279, 1972.

LEVY, Y. The overwintering of Exserohilum turcicum in Israel. Phytoparasitica, v.12, n. 3-4, p.177-182, 1984.

LEVY, Y.; COHEN, Y. Sporulation of Helminthosporium turcicum on sweet corn: effects of light and sugars. Physiological Plant Pathology, v. 18, p. 17-25, 1981. 
LEVY, Y.; COHEN, Y. A negative association between leaf sugar content and the development of northen leaf blight lesions in sweet corn. Physiological Plant Pathology, v.24, p.247-252, 1984.

LEVY, Y.; TAL, K. The effects of water deficiency in corn plants on the development of three corn diseases. Phytoparasitica, v.13, n.2, p.141-144, 1985.

LIPPS, P.E. Survival of Colletotrichum graminicola in infected corn residues in Ohio. Plant Disease, v.67, p.102-104, 1983.

LIU, L.; KLOEPPER, J.W.; TUZUN, S. Induction of systemic resistance in cucumber against bacterial angular leaf spot by plat growth-promoting rhizobacteria. Phytopathology, v.85, n.8, p.843-847, 1995a.

LIU, L.; KLOEPPER, J.W.; TUZUN, S. Induction of systemic resistance in cucumber by plant growth-promoting rhizobacteria: duration of protection and effect of host resistance on protection and root colonization. Phytopathology, v.85, n.10, p.1064$1068,1995 b$.

LOCKWOOD, J.L. The role of microbial energy stress in biological control. In: REUNIÃO BRASILEIRA SOBRE CONTROLE BIOLÓGICO DE DOENÇAS DE PLANTAS, 3., Piracicaba, 1989. Anais. Piracicaba: Reunião Brasileira sobre o Controle Biológico de Doenças de Plantas, 1989, p.3.

LOEFFLER, W.; TSCHEN, J.S.M.; VANITTANAKOM, N.; KUGLER, M; KNORPP, E; HSIEN, T.F.; WU, T.G. Antifungal effects of basilysin and fungymycin from Bacillus subtilis F-93-3: A comparison with activities of other Bacillus antibiotics. Journal of Phytopathology, v.115, p.204-206, 1986. 
LOPEZ, A.M.Q. Controle alternativo da antracnose causada por Colletotrichum graminicola (CES) Wills em sorgo (Sorghum bicolor L. (MOENCH)). Rio Claro, 1991. 203p. Dissertação (M.S.) - Universidade Estadual Paulista "Júlio de Mesquita Filho".

LOPEZ, A.M.Q. Fitoalexinas em sorgo - papel na interação com fungos fitopatogênicos. Summa Phytopathologica, v. 19, n. 1, p.59-61, 1993.

LOPEZ, A.M.Q.; PASCHOLATI, S.F. Accumulation of a complex of pigments in sorghum mesocotyls in response to wounding. Journal of Phytopathology, v.135, p.63-70, 1992.

LOUVET, J.; ALABOUVETTE, C.; ROUXEL, F. Microbiological supressiveness of some soils to Fusarium wilts. In: NELSON, P.E.; TOUSSUN, T.A.; COOK, R.J. (Ed.) Fusarium: Diseases, Biology, and Taxonomy. Pennsylvania: University Park - The Pennsylvania State University, 1981. cap.25, p.261-275.

LOZANO, J.C.; SEQUEIRA, L. Prevention of the hypersensitive reaction in tobacco leaves by heat-killed cells of Pseudomonas solanacearum. Phytopathology, v.60, p. $875-877,1970$.

LUZ, W.C. Microbiolização de sementes para o controle de doenças das plantas. In: LUZ, W.C. (Ed.) Revisão Anual de Patologia de Plantas. Passo Fundo: Revisão Anual de Patologia de Plantas, 1993. p.33-77.

MADAMANCHI, N.R.; KUC, J. Induced systemic resistance in plants. In: COLE, G.T.; HOCH, H.C (Ed.) The Fungal Spore and Disease Initiation in Plants and Animals. New York: Plenum Press, 1991. p.347-362. 
MAKI, C.S. Respostas fungistáticas de Lentinula edodes (Berkeley) Pelgler sobre Candida albicans e análise variabilidade intraespecífica. Londrina, 1999. 116p. Dissertação (M.S.) - Universidade Estadual de Londrina.

MANSFIELD, J.W. Antimicrobial compounds. In: CALLOW, J.A. (Ed.). Biochemical Plant Pathology. London: Chichester, John Wiley \& Sons, 1983. p.237-265.

MARLEY, P.S.; HILLOCKS, R.J. The role of phytoalexins in resistance to Fusarium udum wilt in pigeon pea (Cajamıs cajar). Plant Pathology, v.42, p.212-218, 1993.

MARTINELLI, J.A. Aspects of induced resistance of barley (Hordeum vulgare) to powdery mildew (Erysiphe graminis f. sp. hordei). Summa Phytopathologica, v.18, p.207-219, 1992.

MARTINS, E.M.F. Controle da ferrugem do cafeeiro (Hemileia vastatrix) através da indução de resistência. In: BETTIOL, W. (Ed.) Controle Biológico de Doenças de Plantas. Brasília: Empresa Brasileira de Pesquisa Agropecuária, 1991. cap. 24, p.345-363.

MATTA, E.F. Doenças de maracujazeiro no Estado da Bahia. Salvador: EPABA, 1982. 17p. (Circular Técnica, 2)

MELLO, I.S. Trichoderma e Gliocladium como bioprotetores de plantas. In: LUZ, W.C. (Ed.) Revisão Anual de Patologia de Plantas. Passo Fundo: Revisão Anual de Patologia de Plantas, 1996. p.261-295

MISRA, A.P. Recent trends of researches in graminicolous Helminthosporia. Indian Phytopathology, v.42, n.2, p.209-220, 1989. 
MIZOGUCHI, Y.; KATOH, H.; KOBAYASHI, K.; YAMAMOTO, S.; MORISAWA, S. Effects of extract of cultured Lentimus edodes (LEM) on polyclonal antibody response induced by pokeweed. Gastroenterology Japanese, v.22, n.5, p.627-632, 1987.

MIZUNO, T. Shiitake, Lentinus edodes: funcional properties for medicinal and food purposes. Food Review International, v.11, n.1, p.111-128, 1995.

MOLINA, A.; HUNT, M.D.; RYALS, J.A. Impaired fungicide activity in plants blocked in disease resistance signal transduction. The Plant Cell, v.10, p.1903-1914, 1998.

MOLINA, F.I.; SHEN, P.; JONG, S.C.; ORIKONO, K. Molecular evidence supports the separation of Lentinula edodes from Lentinus and related genera. Canadian Journal of Botany, v.70, p.2446-2452, 1992.

MORAES, W.B.C. Controle alternativo aplicado a cultura de café. In: REUNIÃO BRASILEIRA SOBRE CONTROLE BIOLÓGICO DE DOENÇAS DE PLANTAS, 3., Piracicaba, 1989. Anais. Piracicaba: Reunião Brasileira sobre o Controle de Doenças de Plantas, 1989. p. 36-44p.

MORAES, W.B.C. Indução de resistência em plantas. In: SIMPÓSIO INTERNACIONAL DE CONTROLE BIOLÓGICO, 2, Brasilia: Anais. Brasilia: Simpósio Internacional de Controle Biológico, 1990. p.60-61.

MORAES, W.B.C. Indução de resistência em plantas contra fitopatógenos. In: BETTIOL, W. (Ed.) Controle Biológico de Doenças de Plantas. Brasília: Empresa Brasileira de Pesquisa Agropecuária, 1991. cap.10, p. 157-179. 
MORITA, K.; KOBAYASHI, S. Isolation, struture, and synthesis of Lenthionine and its analogs. Chemical Pharmacological Bulletin, v.15, p.988-993, 1967.

MOURA, C.B.; SILVA, W.J. Efeitos genéticos da resistência de linhagens de milho ao Helminthosporium turcicum Pass. Pesquisa Agropecuária Brasileira, v.16, n.3, p.319-323, 1981.

MOWAT, W.P.; DAWSON, S. Detection and identification of plant viruses by ELISA using crude sap extracts and unfractionated antisera. Journal of Virological Methods, v.15, p.233-247, 1987.

MUCHOVEJ, J.J.; MUCHOVEJ, R.M.C.; RIBEIRO-NESIO, M.L. Taxonomia de Drechslera, Bipolaris e Exserohilum. Fitopatologia Brasileira, v.13, n.3, p.211$223,1988$.

MÜLLER, K.O. Einige einfache Versuche zum Nachweis von Phytoalexinen. Phytopathologische Zeitschrift, v.27, p.237-254, 1956.

MÜLLER, K.O. The phytoalexin concept and its methodological significance. Recent Advances in Botany, v. 1, p.396-400, 1961.

MÜLLER, K.O.; BÖRGER, H. Experimentelle Untersuchungen über die Phytophtora resistenz der Kartoffel. Arbeit Biologische Reichsanstal für Land und Forstwirtschaft, v.23, p.189-231, 1940.

NAMBA, H.; KURODA, $\mathrm{H}$. Antitumor mechanisms of orally administred shiitake fruit bodies. Chemical Pharmacological Bulletin, v. 32, p. 2459-2464, 1997.

NAKAMURA, K.; FERNANDES, N.G. Avaliação da severidade da antracnose em alguns genótipos comerciais de sorgo. Científica, v.10, n. 1, p.135-139, 1982. 
NEWELL, L.; WIDDERS, I.; HAMMERSCHMIDT, R. Acquired disease resistance: A viable strategy for disease managemente in pickling cucumbers. In: PICKLING CUCUMBER IMPROVEMENT COMMITEE MEETING. Chicago: Pickling Cucumber Improvement Commitee Meeting, 1993, p.101-102.

NICHOLSON, R.L. Colletotrichum graminicola and the anthracnose disease of maize and sorghum. In: BAILEY,. J.A; JEGER, M.L. Colletotrichum: Biology, Pathology and Control. Wallingford: CAB International, 1992. cap.9, p.186-202.

NICHOLSON, R.L.; JAMIL, F.F.; SYNDER, B.A.; LUE, W.L.; HIPSKIND, J. Phytoalexin synthesis in the juvenile sorghum leaf. Physiology Molecular Plant Pathology, v.33, p.271-278, 1988.

NICHOLSON, R.L.; MORAES, W.B.C. Survival of Colletotrichum graminicola: importance of the spore matrix. Phytopathology, v.70, n.3, p.255-261, 1980.

NICHOLSON, R.L.; WARREN, H.L. Criteria for evaluation of resistance to maize anthracnose. Phytopathology, v.66, p.86-90, 1976.

OUCHI, S. Induction of resistance or susceptibility. Annual Review of Phytopathology, v.21, p.289-315, 1983.

OUCHI, S.; OKU, H.; HIBINO, C. Localization of induced resistance and susceptibility in barley leaves inoculated with the powdery mildew fungus. Phytopathology, v.66, p.901-905, 1976.

PACCOLA, E.A.S. Estudo do efeito fungistático dos basidiomicetos Lentimula edodes (shiitake) e Agaricus blazei Murril (cogumelo do sol) sobre Candida albicans. Londrina, 1997. 78p. Monografia (Graduação) - Universidade Estadual de Londrina. 
PACUMBABA, R.P.; BEYL, C.A.; PACUMBABA Jr, R.O. Shiitake mycelial leachate suppresses growth of some bacterial species and symptoms of bacterial wilt of tomato and lima bean in vitro. Plant Disease, v.83, n. 1, p.20-23, 1999.

PAIVA, E.; PEIXOTO, M.J.V.V.D.; FERREIRA, A.S.; CASELLA, C.R. Diferenciação imunológica de raças fisiológicas de Colletotrichum graminicola de sorgo. Fitopatologia Brasileira, v. 15, n.4, p.299-302, 1990.

PALVA, T.K.; HURTIG, M.; SAINDRENAN, P.; PALVA, E.T. Salicylic acid induced resistance to Erwinia carotovora subsp. carotovora in tobacco. Molecular PlantMicrobe Interactions, v.67, n.3, p.356-363, 1994.

PASCHOLATI, S.F. Fisiologia do parasitismo: passado, presente e futuro. Summa Phytopathologica, v. 19, n. 1, p.53-55, 1993.

PASCHOLATI, S.F. Indução de resistência em plantas contra fitopatógenos. Summa Phytopathologica, v.23, n.1, p.81-82, 1997.

PASCHOLATI, S.F; DEISING, H.; LEITE, B; ANDERSON, D.; NICHOLSON, R.C. Cutinase and non-specific esterase activities in the conidial mucilage of Colletotrichum graminicola. Physiological and Molecular Plant Pathology, v.42, p.37-51, 1993.

PASCHOLATI, S.F.; HEIM, D.; NICHOLSON, R.L. Phenylalanine ammonia - lyase and susceptibility of maize mesocotyl to Helminthosporium maydis. Physiological Plant Pathology, v.27, p.345-356, 1985.

PASCHOLATI, S.F.; LEITE, B. Mecanismos bioquímicos de resistência às doenças. In: LUZ, W.C.; FERNANDES, J.M.C.; PRESTES, A.M.; PICININI, E.C. (Ed.) Revisão Anual de Patologia de Plantas. Passo Fundo: Revisão Anual de Patologia de Plantas, 1994. p.1-51. 
PASCHOLATI, S.F.; LEITE, B. Hospedeiro: mecanismos de resistência. In: BERGAMIN FILHO, A.; KIMATI, H.; AMORIM, L. (Ed.) Manual de Fitopatologia. 3.ed. São Paulo: Editora Agronômica Ceres Ltda, 1995. cap. 22, p. 417-453.

PASCHOLATI, S.F.; MORAES, W.B.C.; FIGUEIREDO, M.B.; OLIVEIRA, A.R. Induced protection in melon plants against Mycosphaerella melonis by prior inoculation with Helminthosporium carbonum or heat inactivated M. melonis. Fitopatologia Brasileira, v. 11, n.3, p.507-514, 1986.

PASCHOLATI, S.F.; NICHOLSON, R.L. Helminthosporium maydis suppresses expression of resistance to Helminthosporium carbonum in corn. Phytopathologische Zeitschrift, v. 107, p.97-105, 1983.

PASCHOLATI, T.R.P.; PICCININ, E; PASCHOLATI, S.F. Cogumelo comestível shiitake (Lentinus edodes): Influência da temperatura e de nutrientes (carbono, nitrogênio e vitaminas), no crescimento micelial de diferentes isolados $\mathrm{e}$ levantamento da microflora fúngica contaminante de mourões de eucalipto inoculados com o fungo Lentimula edodes. In: SIMPÓSIO DE INICIAÇÃO CIENTÍFICA DA UNIVERSIDADE DE SÃO PAULO, 4., Piracicaba. 1996. Resumos. Piracicaba: ESALQ/USP, 1996. p.419.

PASCHOLATI, T.R.P.; PICCININ, E; PASCHOLATI, S.F. Cogumelo comestivel "shiitake" (Lentinula edodes) estudos fisiológicos, seleção de espécies de Eucaliptus sp., uso de toras "nuas" e levantamento da microflora contaminante de mourões de eucalipto inoculados com o fungo. In: SIMPÓSIO DE INICIAÇÃO CIENTÍFICA DA UNIVERSIDADE DE SÃO PAULO, 5., Piracicaba, 1997. Resumos. Piracicaba: ESALQ/USP, 1997. p.466. 
PAULITZ, T.C. Biochemical and ecological aspects of competition in biological control. In: BAKER, R.R. (Ed.) New Directions in Biological Control: Alternatives for Suppressing Agricultural Pests and Diseases. New York: Liss, 1990. p. 713-724.

PELGLER, D.N. The genus Lentinula (Tricholomataceae tribo Collybieae). Sydowia, v.36, p.227-239, 1983.

PEREIRA, A.L.G. Contribuição ao estudo da etiologia da mancha oleosa da folha de maracujá (Passiflora edulis Sims.) causada por Xanthomonas passiflora n.sp. Piracicaba, 1968. 91p. Tese (Doutorado) - Escola Superior de Agricultura "Luiz de Queiroz", Universidade de São Paulo.

PEZET, R.; PONT, V. Ultrastructural observations of pterostilbene fungitoxicity in dormant conidia of Botrytis cinerea Pers. Journal of Phytopathology, v.129, p.1930,1990 .

PICCININ, E. Uso de Saccharomyces cereviseae na proteção de plantas de sorgo (Sorghum bicolor), maracujá amarelo azedo (Passiflora edulis) e eucalipto (Eucaliptus spp.) contra fitopatógenos fúngicos e bacterianos. Piracicaba, 1995. 105p. Dissertação (M.S.) - Escola Superior de Agricultura "Luiz de Queiroz", Universidade de São Paulo.

PICCININ, E; MALAVOLTA JÚNIOR, V.A.; PASCHOLATI, S.F. Efeito da concentração de inóculo e da temperatura na severidade de Xanthomonas campestris pv. passiflora em folhas de maracujazeiro. Fitopatologia Brasileira, v.20, p.323, 1995. Suplemento. 
PICCININ, E.; PASCHOLATI, S.F. Influência de preparações do cogumelo "shiitake (Lentinus edodes) sobre o crescimento micelial de Exserohilum turcicum. In: CONGRESSO BRASILEIRO DE FITOPATOLOGIA, 30., Poços de Caldas, 1997. Resumos. Poços de Caldas: Congresso Brasileiro de Fitopatologia, 1997. p.297.

PIGA, P.M; BÉLANGER, R.R.; PAULITZ, T.C.; BENHAMOU, N. Increased resistance to Fusarium oxysporum f. sp. radicis-lycopersici in tomato plants treated with the endophytic bacterium Pseudomonas fluorecens strain 63-28. Physiological and Molecular Plant Pathology, v.50, p.301-320, 1997.

POSTMA, J.; LUTTIKHOLT, A.J.G. Colonization of carnation stems by a nonpathogenic isolate of Fusarium oxysporum and its effect on Fusarium oxysporum f. sp. dianthi. Canadian Journal of Botany, v.74, p. 1841-1851, 1996.

PRABHU, A.S.; MORAIS, O.P. Resistência estável às doenças de plantas. In: LUZ, W.C.(Ed.) Revisão Anual de Patologia de Plantas. Passo Fundo: Revisão Anual de Patologia de Plantas, 1993. p.239-273.

PRASAD, K.V.V.; KHARE, M.N.; JAIN, A.C. Site of infection and further development of Colletotrichum graminicola (Ces.) Wilson in naturally infected sorghum grains. Seed Science \& Tecnology, v.13, p.37-40, 1985.

PAXTON, J.D. Phytoalexins - a working redefinition. Phytopathologische Zeitschrift, v.101, p.106-109, 1981.

PRZYBYLOWICZ, P, DONOGHUE, J. Shiitake grower's handbook: the art and science of mushroom cultivation. Dubuque: Kendall/Hunt, 1990. 217p. 
RAAIJMAKERS, J.M.; LEEMAN, M.; VAN OORSCHOT, M.M.P.; VAN DER SLUIS, I.; SCHIPPERS, B; BAKKER, P.A.H.M. Dose-response relationships in biological control of Fusarium wilt of radish by Pseudomonas spp. Phytopathology, v. 85, n. 10, p. $1075-1081,1995$.

RAMADOSS, C.S.; UHLIG, J.; CARLSON, D.M.; BUTLER, L.G.; NICHOLSON, R.L. Composition of the mucilaginous spore matrix of Colletotrichum graminicola a pathogen of corn, sorghun, and other grasses. Journal of Agriculture and Food Chemistry, v.33, p. 728-732, 1985.

RASMUSSEN, J.B.; HAMMERSCHMIDT, R.; ZOOK, M.N. Systemic induction of salicylic acid accumulation in cucumber after inoculation with Pseudomonas syringae pv. syringae. Plant Physiology, v.97, p.1342-1347, 1991.

RAUPACH, G.S.; LIU, L.; MURPHY, J.F.; TUZUN, S.; KLOEPPER, J.W. Induced systemic resistance in cucumber and tomato against cucumber mosaic cucumovirus using plant growth-promoting rhizobacteria (PGPR). Plant Disease, v.80, n.8, p.891894, 1996.

RAY, J. Cultures et formes attènuès des maladies cryptogamiques des vègètaux. Comptes Rendus Hebdomadaires des Seances de l'Academie des Sciences, v.133, p.307-309, 1901 .

REIS, E.M. Solos supressivos a doenças de plantas. In: REUNIÃO BRASILEIRA SOBRE CONTROLE BIOLÓGICO DE DOENÇAS DE PLANTAS, 2., Piracicaba, 1987. Anais. Piracicaba: Reunião Brasileira sobre Controle Biológico de Doenças de Plantas, 1987. p.42-48. 
REIS, E.M. Possibilidades de controle biológico do mal do pé do trigo. In: REUNIÃO BRASILEIRA SOBRE CONTROLE BIOLÓGICO DE DOENÇAS DE PLANTAS, 3., Piracicaba, 1989. Anais. Piracicaba: Reunião Brasileira sobre Controle Biológico de Doenças de Plantas, 1989. p.49-56.

REUVENI, R.; REUVENI, M.; AGAPOV, V. Foliar spray of NPK fertilizers induce systemic protection against Puccinia sorghi and Exserohilum turcicum and growth response in maize. European Journal of Plant Pathology, v. 102, p.339-348, 1996.

ROMEIRO, R.S.; KIMURA, O. Induced resistance in pepper leaves infiltrated with purified bacterial elicitors from Xanthomonas campestris pv. versicatoria. Journal of Phytopathology, v.145, p.495-498, 1997.

ROMEIRO, R.S.; MUCHOVEJ, J.J. Persistance and lack of absorption and translocation of streptomycin sulfate in passion fruit leaves. Turrialba, v.40, n.4, p. $487-490,1990$

RONCATTO, M.C.; PASCHOLATI, S.F. Mesocótilos estiolados de sorgo: bioensaio para a caracterização de frações de Saccharomyces cerevisiae envolvidas na proteção de plantas de sorgo contra fungos. In: REUNIÃO ANUAL DO INSTITUTO BIOLÓGICO, 6., São Paulo, 1993. Resumos. São Paulo: Instituto Biológico 1993. p.31.

ROSS, A.F. Systemic acquired resistance to plant virus infection in hypersensitive host. Virology, v. 14, p.329-339, 1961.

ROULIN, S.; BUCHALA, A.J. The induction of $\beta$-1,3-glucanase and other enzymes in groundnut leaves infected with Cercospora arachidicola. Physiological and Molecular Plant Pathology, v.46, p.471-489, 1995. 
ROVERATTI, D.S. Proteção de plantas de café (Coffea arabica L.) contra Hemileia vastatrix Berk. et $\mathrm{Br}$. por Saccharomyces cerevisiae. Piracicaba, 1989. 94p. Dissertação (M.S.) - Escola Superior de Agricultura "Luiz de Queiroz", Universidade de São Paulo.

ROVERATTI, D.S.; TEIXEIRA, A.R.R.; MORAES, W.B.C. Controle alternativo da ferrugem de cafeeiro pela utilização de produtos comerciais a base de Bacillus thuringiensis. Fitopatologia Brasileira, v.12, n.2, p.137, 1987. (Resumo)

ROVIRA, A.D.; WILDERMUTH, G.B. The nature and mechanisms of suppression. In: ASCHER, M.J.C.; SHIPTON, P.J. (Ed.) Biology and Control of Take-all. London: Academic Press, 1981. p.385-415.

RYALS, J.A; NEUENSCHWANDER, U.H.; WILLITS, M.G.; MOLINA, A.; STEINER, H.; HUNT, M.D. Systemic acquired resistance. The Plant Cell, v.8, p. $1809-1819,1996$.

SAINDRENAN, P; GUEST, D.I. Involvement of phytoalexins in the response of phosphonate-treated plants to infection by Phytophythora species. In: DANIEL, M.; PURKAYASTHA, R.P. (Ed.) Handbook of phytoalexins and action. New York: Marcel Dekker Inc, 1995. cap. 16, p. 375-390.

SANHUEZA, R.M.V. Práticas agrícolas e sua influência no controle biológico de doenças. In: REUNIÃO BRASILEIRA SOBRE CONTROLE BIOLÓGICO DE DOENÇAS DE PLANTAS, 2., Piracicaba, 1987. Anais. Piracicaba: Reunião Brasileira sobre Controle Biológico de Doenças de Plantas, 1987. p.31-35.

SANHUEZA, R.M.V. Controle biológico de fitopatógenos em casa de vegetação. In: REUNIÃO BRASILEIRA SOBRE CONTROLE BIOLÓGICO DE DOENÇAS DE PLANTAS, 4., Campinas, 1991. Anais. Campinas: Reunião Brasileira sobre o Controle Biológico de Doenças de Plantas, 1991. p.107-114. 
SARKAR, S.; KOGA, J.; WHITLEY, R.J.; CHATTERJEE, S. Antiviral effect of the extract of culture medium of Lentinus edodes mycelia on the replication of herpes simplex virus type1. Antiviral Research, v.20, p.293-303, 1993.

SEAH, S.M.; SILVASITHAMPARAM, K.; TURNER, D.W. The effect os salicylic acid on resistance in wheat (Triticum aestivum) seedling roots against the take-all fungus, Gaeumannomyces graminis var. tritici. Australian Journal of Botany, v.44, p.499-507, 1996.

SEQUEIRA, L. The acquisition of systemic resistance by prior inoculation. In: DALY, J.M \& URITANI, I. (Ed.) Recognition and Specificity in Plant Host-Parasite Interactions. Tokio: Science Society, 1979. p.231-251.

SEQUEIRA, L. Mechanisms of induced resistance in plants. Annual Review of Microbiology, v.37, p.51-79, 1983.

SHEERE, M.P.; LUKE, P. Inability of Exserohilum turcicum (Pass.) Leo et Sug. to survive as a saprophyte in soil in situ. Plant and Soil, v.74, p.141-144, 1983.

SHERRIFF, C.; WHELAN, M.J.; ARNOLD, G.M.; BAILEY, J.A. rDNA sequence analysis confirms the distinction between Colletotrichum graminicola and $C$. sublineolum. Mycological Research, v.99, p.475-478, 1995.

SHEW, H.D.; LUCAS, G.B. (Ed.) Compendium of tobacco diseases. Saint Paul: The American Phytopathological Society, 1991. 68p.

SHIRAISHI,T; YAMADA,T; ICHINOSE,Y; KIBA,A; TOYODA,K. The role of supressors in determinig host-parasite specificities in plant cells. International Review of Cytology, v. 172, p.55-93, 1997. 
SIDDIQUI, M.R.; MATHUR, S.B.; NEERGAARD, P. Longevity and pathogenicity of Colletotrichum spp. in seed stored at $5^{\circ} \mathrm{C}$. Seed Science \& Technology, v.11, p.353$361,1983$.

SILVA, S.R. Aspectos do controle da antracnose em plantas de milho (Zea mays L.), mantidas em casa de vegetação, pelo emprego de Sacharomyces cerevisiae Meyen. Piracicaba, 1989. 81p. Dissertação (M.S.) - Escola Superior de Agricultura "Luiz de Queiroz", Universidade de São Paulo.

SILVA, S.R.; PASCHOLATI, S.F. Sacharomyces cerevisiae protects maize plants, under greenhouse conditons, against Colletotrichum graminicola. Zeitschrift für Pflanzenkrankheiten und Pflanzenschutz, v.99, n.2, p.159-167, 1992.

SINGER, R. Mushrooms and truffles botany, cultivation and utilization. London: Leonard Hill, 1961. 272p.

SMITH, E.F.; BROWN, N.A.; TOWSED, C.O. Crown gall of plants: its cause and remedy. United States: U.S. Department of Agriculture Bureau Plant Industry Bulletin, 1911. v.213.

SNYDER, B.A.; NICHOLSON, R.L. Synthesis of phytoalexins in sorghum as a sitespecific response to fungal ingress. Science, v.248, p.1637-1639, 1990.

SORIMACH, K, NIWA, A.; YAMAZAKI, S.; TODA, S.; YASUMURA, Y. Anti-viral activity of water-solubilized lignin derivatives in vitro. Agricultural and Biological Chemistry, v. 54, n. 5, p.1337-1339, 1990.

STACKMAN, E.C. Relation between Puccinia graminis and plants highly resistant to its attack. Journal of Agricultural Research, v.4, p.191-200, 1915. 
STANGARLIN, J.R.; PASCHOLATI, S.F. Proteção de plântulas de milho pipoca contra Exserohilum turcicum pelo uso de Saccharomyces cerevisiae. Summa Phytopathologica, v.20, n.1, p. 16-21, 1994.

STANGARLIN, J.R.; PICCININ, E.; DA GLORIA, B.A.; OSWALD, W.; PASCHOLATI, S.F. Aspectos histológicos e bioquímicos da interação Exserohilum turcicum e tecido foliar de sorgo. Fitopatologia Brasileira, v.19, p.274, 1994 (Suplemento).

STOESSL, A. Secondary plant metabolites in plant disease resistance. II - Phytoalexins. Fitopatologia Brasileira, v.11, p.25-53, 1986.

SUGANO, N.; CHOJ, Y.; HIBINO, Y.; YASUMURA, S.; MAEDA, H. Anticarcinogenic action of an alcohol-insoluble faction (LAP1) from culture medium of Lentinus edodes mycelia. Cancer Letters, v.27, p.1-6, 1985.

SUGANO, N.; HIBINO, Y.; CHOJI, Y.; MAEDA, H. Anticarcinogenic actions of water-soluble and alcohol insoluble fractions from culture medium of Lentinus edodes mycelia. Cancer Letters, v. 17, p. 109-114, 1982.

SUGIYAMA, K.; AKACHI, T.; YAMAKAWA, A. The hypocholesterolemic action of Lentinus edodes is evoked through alteration of phospholipid composition of liver microsomes in rats. Bioscience Biotechnology and Biochemistry, v.57, n.11, p.1983-1985, 1993.

SUGIYAMA, K.; AKACHI, T.; YAMAKAWA, A. The hypocholesterolemic action of eritadenine is mediated by a modification of hepatic phospholipid metabolism in rats. The Journal of Nutrition, v. 125, n.8, p.2134-2144, 1995. 
SUZUKI, F.; KOIDE, T.; TSUNODA, A.; ISHIDA, N. Mushroom extracts as an interferon inducer, biological and physiochemical properties of spore extracts of Lentinus edodes. Mushroom Science, v.9, p.509-519, 1974.

SUZUKI, F.; SUZUKI, C.; SHIMOMURA, E.; MAEDA, H.; FUJI, T.; ISHIDA, N. Antiviral and interferon-inducing activities of a new peptidomannan, KS-2, extrated from culture mycelia of Lentimus edodes. The Journal of Antibiotics, v.32, n.12, p.1336-1345, 1979.

SUZUKI, H.; IIYAMA, K; YOSHIDA, O.; YAMAZAKI, S.; YAMAMOTO, N.; TODA, S. Structural characterization of the immunoactive and antiviral watersolubilized lignin in an extract of the culture medium of Lentinus edodes mycelia (LEM). Agricultural Biological and Chemistry, v.54, n.2, p.479-487, 1990.

SUZUKI, H.; OBUKO, A.; YAMAZAKI, S.; SUZUKI, K.; MITSUYA, H.; TODA, S. Inhibition of the infectivity and cytophathic effect of human immunodeficiency virus by water-soluble lignin in an extract of the culture medium of Lentimus edodes mycelia (LEM). Biochemical and Biophysical Research Communications, v. 160, n. 1, p. 367-373, 1989 .

SUZUKI, H; OBUKO, A. YAMAZAKI, S.; TODA, S. Immunopotentiating substances in Lentimus edodes mycelial extract (LEM) - Activation of macrophage and proliferation. Japanese Journal Gatroenterology, v.85, n.7, p. 1430, 1988

SUZUKI, H.; SAITO, H.; OBUKO, A.; YAMAZAKI, S.; TODA, S. Immunological activities of high molecular weight fractions purified from Lentinus edodes extract (LEM) - macrophage - activating effect and mitogenic activity. Igaku no Ayumi, v.138, p.441-442, 1986. 
SUZUKI, M.; TAKATSUKI, F.; MAEDA, Y.Y.; HAMURO, J.; CHIHARA, G. Antitumor and immunological activity of Lentinan in comparision with LPS. International Journal Immunopharmacology, v. 16, n.5/6, p.463-468, 1994.

TAKAGI, Y.; SHIGIMURA, Y. Inhibitory effect of aqueous extract of fruit bodies of Lentimus edodes (Berk.) Sing. on plant virus. Proceedings of the Kansai Plant Protection Society, n.6, p.11-16, 1977.

TAKAGI, Y,; SHIMADA, K. Inhibitory effect of aqueous extracts from the sawdust rice bran media on which Lentinus edodes or Flamulina velutipes had grown. Annals of the Phytopatholological Society of Japan, v.43, n.2, p.211-214, 1977.

TAKAGI, Y.; SHIMADA, K.; IIDA, S. Inhibition of tobacco mosaic virus infection and multiplication by aqueous extracts from the sawdust rice bran media with grown mycelia of some edible fungi. Annals of the Phytopatholological Society of Japan, v.43, n.2, p.215-218, 1977.

TAKAZAWA, H.; TAJIMA, F.; MIYASHITA, C. An antifungal compound from "shiitake"(Lentinus edodes). Yakugaku Zasshi, v.102, n.5, p.489-491, 1982.

TAKEHARA, M.; KUIDA, K.; MORI, K. Antiviral activity of virus-like particles from Lentinus edodes (shiitake). Archives of Virology, v.59, p.269-274, 1979.

TAKERECHI, A.; OKANO, T.; TEROAKA, S.; MURAKAMI, Y.; SAYAMOTO, M.; SAWAMURA, S.; KOBAYASHI, T. Identification and determination of vitamin D2 in shiitake, Lentimus edodes. Vitamins, v.58, n.9-10, p.439-448, 1984.

TENKOUANO, A.; MILLER, F.R.; HART, G.E.; FREDERIKSEN, R.A.; NICHOLSON, R.L. Phytoalexin assay in juvenile sorghum: an aid to breeding for anthracnose resistance. Crop Science, v.33, p.243-248, 1993. 
TOGAMI, M.; TAKEUCHI, I.; IMAIZUMI, F.; KAWAKAMI, M. Basidiomycetes 1. Antitumor polysaccharide from bagasse medium on witch mycelia of Lentinus edodes had been grown. Chemical Pharmacological Bulletin, v.30, n.4, p.1134-1140, 1982.

TOKESHI, H. Manejo da microflora epifita no controle de doenças de plantas. In: REUNIÃO BRASILEIRA SOBRE CONTROLE BIOLÓGICO DE DOENÇAS DE PLANTAS, 4., Campinas, 1991. Anais. Campinas: Reunião Brasileira sobre o Controle Biológico de Doenças de Plantas, 1991, p.32-62.

TOKESHI, H. Controle de doenças pela mudança do ambiente. Summa Phytopathologica, v.23, n.1, p.82-84, 1997.

TOKESHI, H.; SALGADO, C.L. Doenças do fumo - Nicotiana tabacum L. In: GAlli, F.; CARVAlHO, P.C.T.; TOKESHI, H. et al. Manual de Fitopatologia. São Paulo: Editora Agronômica Ceres Ltda, 1980. v.2. p.323-334.

TOLEDO, C. (coordenador) et al. Pragas e Doenças do Maracujá. Campinas: CATI, 1992. 9p. (Comunicado Técnico, n.96)

TORRES FILHO, J.; PONTE, J. Estudo sobre o controle da bacteriose ou "morte precoce" (Xanthomonas campestris pv. passiflora) do maracujá amarelo (Passiflora edulis f. flavicarpa). Fitopatologia Brasileira, v. 19, n. 1, p.34-38, 1994.

TRONSMO, A.; DENNIS, C. The use of Trichoderma species to control strawberry fruit rots. Netherland Journal of Plant Pathology, v.83, p.449-455, 1977.

TSCHEN, J.S.M. Control of Rhizoctonia solani by Bacillus subtilis. Transcontinental Mycological Society of Japan, v.28, p.483-493, 1987. 
TSUNEDA, A.; THORN, G. Interactions between Lentinula edodes and pseudomonads. Canadian Journal of Microbiology, v.40, n. 11, p. 937-943, 1994.

ULLSTRUP, A.J. A comparison of monogenic and polygenic resistance to Helminthosporium turcicum in corn. Phytopathology, v.60, p.1597-1599, 1970.

VANDERPLANK, J.E. Plant Diseases: Epidemics and Control. New York: Academic Press, 1963. 349p.

VANDERPLANK, J.E. Disease Resistance in Plants. New York: Academic Press, 1968. 206p.

VASUDEVA, R.S.; SUBBATAN, T.B.; SASTRY, M.L.M.; RANGSWAMI, G; IYENGAR, M.R.S. Bulbiformim, an antibiotic produced by Bacillus subtilis. Annual of Applied Biology, v.46, p.336-345, 1958.

VIZVARY, M.A.; WARREN, H.L. Survival of Colletotrichum graminicola in soil. Phytopathology, v. 72, n.5, p.522-525, 1981.

WARD, H.M. Recent researches on the parasitism of fungi. Annals of Botanic, v.19, p.1-54, 1905 .

WASSER, S.P.; WEIS, A.L. Therapeutic effects of substances occuring in higher basidiomycetes mushrooms: A modern perspective. Critical Reviews in Immunology, v. 19, p.65-96, 1999

WEI, G.; KLOEPPER, J.W; TUZUN, S. Induced systemic resistance to cucumber diseases and increased plant growth by plant growth-promoting rhizobacteria under field conditions. Phytopathology, v.86, n.2, p.221-224, 1996. 
WELLER, D.M. Biological control of soilborne plant pathogens in the rhizosphere with bacteria. Annual Review of Phytopathology, v.26, p.379-407, 1988.

WILSON, C.L.; EL GHAOUTH, A.; CHALUTZ, E.; DROBY, S.; STEVENS, C.; LU, J.Y.; KHAN, V.; ARUL, J. Potential of induced resistance to control postharvest diseases of fruits and vegetables. Plant Disease, v.78, n.9, p.837-844, 1994.

WINDELS, C.E.; LINDOW, S.E. Biological Control on the Phylloplane. 2.ed. Saint Paul: The American Phytopathological Society, 1985. 169p.

YAMAMOTO, Y.; SHIRONO, H.; KONO, K.; OHASHI, Y. Immunopotentiating activity of the water-soluble lignin rich fraction prepared from LEM - The extract of the solid culture medium of Lentinus edodes mycelia. Bioscience Biotechnology Biochemistry, v.61, n.11, p.1909-1912, 1997.

YAMAMURA, Y.; COCHRAM, K.W. A seletive inhibitor of myxoviruses from shiitake (Lentinus edodes). Mushroom Science, v.9, n. 1, p.495-507, 1976.

YANG, X.T.; YANG, Q.Y. The isolation, purification and identification of the two new polysaccharides (Le 2-1 and Le 2-2) of the mycelia of Lentimus edodes. In: INTERNATIONAL CONGRESS ON THE SCIENCE AND CULTIVATION OF EDIBLE FUNGI, 14., Oxford, 1995. Conference Proceedings of the $14^{\text {th }}$ International Congress on the Science and Cultivation of Edible Fungi. Oxford: $14^{\text {th }}$ International Congress on the Science and Cultivation of Edible Fungi, 1995. p. $570-571$.

YE, N.S.; PAN, S.Q.; KUC, J. Pathogenesis-related proteins and systemic resistance to blue mould and tobacco mosaic virus induced by tobacco mosaic virus, Peronospora tabacina and aspirin. Physiological and Molecular Plant Physiology, v.35, p.161$175,1989$. 
YPEMA, H.L.; GOLD, R.E. Kresoxim-methyl: modification of a naturally occurring t compound to produce a new fungicide. Plant Disease, v.83, n. 1, p.4-19, 1999.

YOSHIDA, O.; NAKASHIMA, H.; YOSHIDA, T.; KANEKO, Y.; YAMAMOTO, I.; MATSUZAKI, K; URYU, $T$; YAMAMOTO, N. Sulfation of the immunomodulating polysaccharide Lentinan: A novel strategy for antivirals to human immunodeficiency virus (HIV). Biochemistry and Pharmacology, v.37, n.15, p.2887-2891, 1988.

YU, H.; SUTTON, J.C. Density dynamics of Gliocladium roseum in relation to biological control of Botrytis cinerea in red raspberry. Canadian Journal of Plant Pathology, v.21, p.23-32, 1999.

XUE, L.; CHAREST, P.M.; JABAJI-HARE, S.H. Systemic induction of peroxidases, $1,3-\beta$-glucanases, chitinases, and resistance in bean plants by binucleate Rhizoctonia species. Phytopathology, v.88, n.4, p.359-365, 1998. 